PS01-01 胸部食道癌リンパ節転移診断の問題点ーリンパ節径およ び形状からみたリンパ節転移の予湘一

船井隆伸", 大杉治司", 徳原太豪", 高田信康", 竹村雅至", 東野正 幸"，木下博明'

(大阪市立大学第 2 外科 ${ }^{17}$, 大阪市立総合医療センター消化器外科 ${ }^{21}$ )

<目的 > 胸部食道癌に対する根治の可能性, 郭清の適応を予測するう えで重要なリンパ節転移は主にその径で診断されている．しかし未だ診 断基準はない。一方 3 領域郭清例の蓄積によりリンパ節転移の実態が明 らかになってきたそそこで手術で得られた新鮮リンバ節標本の径から転 移診断基準を設けその意義について検討した. 〈方法〉 3 領域リンパ 節郭清施行胸部食道僢 123 例から得られた 6822 個の新鮮リンパ節を $\mathrm{A}$ 群 (No100,101,102,104), B 群 (No106 rec, tb), C 群 (No107,109), D 群 (No105,108,110,111,112), E 群 (Nol, 2,3), F 群 (No7, 8,9) に分類, 各リンパ節の最長径を大きさの, 長短径比 (短径/長径)を形状の指標と した．各群ごとにリンパ節径について ROC 解析を行い転移診断基準を 求めた. 〈結果〉 リンパ節径から転移の予測は可能であった。転移診 断のカットオフ值 (sensitivity/specificity) はA 群 $5 \mathrm{~mm}(80 \% / 68 \%)$, $\mathrm{B}$ 群 $8 \mathrm{~mm}(77 \% / 67 \%), \mathrm{C}$ 群 $10 \mathrm{~mm}(61 \% / 73 \%), \mathrm{D}$ 群 $8 \mathrm{~mm}(80 \% / 68$ $\%)$, E 群 $6 \mathrm{~mm}(65 \% / 72 \%), \mathrm{F}$ 群 $6 \mathrm{~mm}(69 \% / 57 \%)$ であった。 径 10 $\mathrm{mm}$ 未満のリンパ節は転移の有無にかかわらず球形を呈することが多 かったが, 径 $10 \mathrm{~mm}$ 以上のリンパ節では転移により有意に球形を呈し た. 〈考案・総括〉 遠隔転移と考えられる A 群, F 群へのリンパ節転 移の診断能は低く、リンパ節を検出すれば転移の可能性が高い. 郭清に 際し細心の注意を必要とする B 群，C 群の正確なりンパ節転移診断は CT では困難で反回神経麻疸や肺合併症を回避するためにも術前超音波 内視鏡による検索が必要である。リンパ節径をもとにした転移診断は困 難である. staging を的確におこなうためにも 3 領域リンパ節郭清は必 要である.

PS01-02 胸部食道癌から最初に転移するリンパ節領域および pNO 症例に扩ける微少りンパ節転移の検討

前田賢人, 嶋田 裕, 永谷史朗, 今村正之

(京都大学医学研究科腫瘍外科)

【目的】近年, 消化器癌においても sentinel node の検索を指標にリンパ節 郭清範囲を決定しょうとする動きが始まっている. 胸部食道煰のリンパ 節転移の病態は複雑多様とされているが, 胸部食道癌のリンパ節転移が どこから始まるかを検討する目的に, 特にリンパ節転移が 1 領域に限ら れる症例の転移先を調べた. さらに主病巣の局在が $\mathrm{Mt}$ の症例中, 通常病 理検索により $\mathrm{pNO}$ とされた症例における微少りンパ節転移の存在部位 およびその有無が術後のリンパ節再発に及ほす影響もあわせて検討し た.【対象】 1990 年 1 月より 2000 年 12 月まで当科で施行された胸部食道 癌切除症例 249 例 (Ut：37 例, Mt : 146 例, Lt : 66 例) の中, 1 領域に のみ転移があったもの (Ut：9 例, Mt $: 27$ 例, Lt $: 9$ 例)を対象とした. $\mathrm{Mt}$ 症例で $\mathrm{pN} 0$ であった 63 例中 32 例で微少転移の検索も行った.【方 法】摘出されたリンパ節の HE 染色による通常病理検索およびサイトケ ラチン免疫染色による微少転移の検索を施行した【結果】 Ut $: 9$ 症例で の転移先は頝部と上縦隔で, 106tbL であった 1 例を除き 1 群リンパ節で あった. Mt：27 例では頝部から腹部まで広範に分布し, 1 例は 3 群の 104 であった. Lt : 9 例では上縦隔から腹部にわたり, 3 群の 105 および 4 群の 11 が各 1 例ずつみられた。 また, HE 染色でリンパ節転移がない とされた Mt の 32 例中 12 例に微少転移がみられ, その範囲は暄部から 腹部にまたがっていた. HE 染色でリンパ節転移がなかった症例中, 微少 転移もなかった 20 例では術後 5 年以内に 1 例 $(5.0 \%)$ のみがリンパ節再 発を来したが，微少転移があった 12 例では 4 例 $(33.3 \%)$ がリンパ節再 発を来した.【総括】胸部食道癌の最初の転移部位は広範に分布し, 特に Mt および Lt 症例では, HE 検索上,いきなり 3 群以遠のリンパ節へ跳躍 転移するものもあり, sentinel node の決定が容易でないことがあらため て示された。 また, 通常病理検索で $\mathrm{pNO}$ と診断されても微少転移がある ものではリンパ節再発を来しやすいことが示唆され, 微少リンパ節転移 の有無は一定の予後因子となりうるものと考えられた。
PS01-03 リンパ節郭清からみた食道癌 TNM 分類に扔ける M1リ ンパ節の意義と問題点

羽成直行, 松原久裕, 岡住慎一, 宮澤幸正, 舟波 裕, 松下一之, 浦島 哲朗, 外浦 功, 阿久津泰典, 川槝太一, 森 幹人, 落合武德 (千葉大学第二外科)

【目的】近年 EBM の立場から世界共通の evidence として論文に基づい た治療方針の決定が行われるが，英文誌においては主に TNM 分類が採 用されている. 食道癌の TNM 分類ではリンパ節は領域リンパ節とそれ 以外に分けられ, 領域リンパ節以外の転移は遠隔転移として扱ってい る. 胸部食道癌 3 領域リンパ節郭清例の検討により, この分類の妥当性, また M1 リンパ節のなかに他の遠隔転移と同じ群として分類可能な領 域が存在するかを考察し, その問題点を明らかにする.【対象】1983 年か ら 1999 年に当科で 3 領域郭清を施行した胸部食道癌症例 226 例中, 頸 部および腹部リンパ節転移を認めた 85 例と, M1 リンパ節以外の他臟器 転移にて非切除症例となった 29 例.【方法】頸部リンパ節を胸部食道か ら 101,104,102,100,103 番の順に位置すると仮定し, 頸部リンパ節転移陽 性例を 101 まで, 104 まで, 102 まで, 100 および 103 まで転移の 4 群に 分類し, 予後を算出する. また各群と他蔵器転移症例を比較し, 他臓器 転移に匹敵するリンパ節転移領域を検討した.【結果】 M1 リンパ節以外 の他臓器転移で非切除とした 29 例の $1,3,5$ 生率はそれぞれ 6.9, 3.5, 3.5\% であった。一方, 胸部食道癌切除例の頸部リンバ節の陽性症例で 101 番まで転移を認めたのは 7 例で $1,3,5$ 生率は $57.1,38.1,38.1 \%$, 同様に 104 番までは 41 例， $49.9,18.1,10.9 \% ， 102$ 番まで 21 例， $60.2,7.5,7.5 \%$, 100 および 103 番までは 3 例, $33.3,0.0,0.0 \%$ であった。他臓器転移によ る非切除症例と予後に有意差を認めない群は 100 および 103 番まで転 移のあった群のみであり $(\mathrm{p}=0.075)$, これ以外の 102 番までの転移例で は非切除例より有意に予後が良好であった $(\mathrm{p}=0.0000069)$.【結論】胸部 食道癌の頸部リンパ節転移においては 100 番または 103 番に転移陽性 例が M1 リンパ節に相当すると考えられた. 今後腹部リンパ節について も考察を加える.

PS01-04予後と再発からみた胸部食道癌三領域郭清術の問題点 田平洋一, 安永正浩, 中野敢友, 坂口智則, 松下尚之, 福永剛隆, 永本 展英, 平岡武久, 川筋道雄

(熊本大学第一外科)

(目的)胸部食道癌三領域郭清術例の予後を調べ，その問題点を明らかに する. (対象) 1984 年から 1999 年までに当施設で切除した胸部食道癌の うち他臟器重複癌合併例を除いた三領域郭例 94 例を対象とした. 男性 80 例, 女性 14 例. 年齢は 39 藏から 76 歳 (平均 61.8 歳) で, 観察期間 は 0 月から 170 月(メディアン：34.5月)であった. pTla：4, pT1b：18, pT2 : 12, pT3 $: 55$, pT $4: 5$ 例であった. 生存 39 例, 死亡 55 例 (原病死： 35 , 他病死：19, 不明：1) であった. (方法) リンパ節転移個数別 (4 個以 下, 5 個以上), 転移率別 ( $10 \%$ 末満, $10 \%$ 以上)に生存曲線を比較した. 術後合併症の種類と頻度および再発形式を検討した。遠隔転移，播種性 転移の関連因子を多変量（ロジスティック）解析で求めた。生存曲線は Kaplan-Meier 法で求め, Log-rank test で比較した. $\mathrm{p}<0.05$ を有意差あ りとした. (結果) 94 例の 5 年生存率は $43.7 \%$ であった。転移個数別の 5 年生存率は個数 4 個以下では $55.9 \%$, 個数 5 個以上では $8.7 \%$ であった $(\mathrm{p}<0.0001)$. 転移率別の 5 年生存率は $10 \%$ 未満で $51.0 \%, 10 \%$ 以上で $7.1 \%$ であった $(\mathrm{p}<0.0001)$. 術後合併症は縫合不全 16 例, 肺合併症 14 例, 反回神経麻瘦 9 例, 創感染 5 例, イレウス 2 例などであった。術死 例は 2 例 $(2.1 \%)$ でともに縫合不全による敗血症が死因であった，再発 例は 38 例 $(40.4 \%)$ で, 初発再発部位は遠隔臟器再発 16 例 (肺 $: 7$, 肝 : 3 , 皮有 $: 2$, 筋 $: 2$, 脳: 1 , 骨: 1 ), リンパ節再発 11 例 (上縦郭：6, 頸部： $5)$, 局所再発 6 例, 播種性再発 5 例であった。転移個数 4 個以下 71 例中 20 例 $(28.2 \%)$ と 5 個以上例 23 例中 15 例 $(65.2 \%)$ が再発死していた. 迋隔・播種性再発の関連因子は転移個数 $(\mathrm{p}=0.04$, オッズ比 : 0.88$)$ で あった. (まとめ) 三領域郭清術は安全な術式であるが, リンパ節転移個 数多数例には意義が少ない. 転移個数少数例でも再発例が約 $30 \%$ あり, 集学的治療の充実，転移例の予測などが必要である. 
PS01-05胸部食道癌の治療成績からみた 3 領域リンパ節郭清の適 応

秋山浩利, 小野秀高, 松田悟郎, 野村直人, 国崎主税, 嶋田 紘 (横浜市立大学第二外科)

【目的】胸部食道癌のリンバ節郭清領域別の治療成績, 術後合併症および 術後 QOL の検討から 3 領域リンパ節郭清の適応について考察した. 【対 象・方法】 1994 年 5 月より 2000 年 12 月までに 2 領域以上の郭清を施行 L, 根治度 A,B となった胸部食道癌 82 例 ( 2 領域郭清 50 例 $=2 \mathrm{~F}$ 群, 3 領域郭清 32 例 $=3 \mathrm{~F}$ 群) を対象とした. $3 \mathrm{~F}$ 群における頝部りンパ節転移 の予測因子と全症例における予後規定因子についてロジスティック重 回帰分析を用いて検討した.さらに $2 \mathrm{~F}$ 群と $3 \mathrm{~F}$ 群の治療成績を検討する とともに, 2 年以上無再発生存の 18 例 ( $2 \mathrm{~F}$ 群 8 例， $3 \mathrm{~F}$ 群 10 例) につい て術後 QOL を比較検討した.【結果】占拠部位, 腫瘍径, 壁深達度, 組織 型, No. 106 転移の中で頚部リンパ節転移の予測因子なかった. 年齢, 占 拠部位, 腫瘍径, 壁深達度, 組織型, 肉眼型, リンパ節転移, リンパ節 転移個数,リンパ節転移領域，郭清領域のうちリンパ節転移個数のみが 独立した予後規定因子であった. $2 \mathrm{~F}$ 群と $3 \mathrm{~F}$ 群の 5 年生存率をリンパ節 転移個数別（3 個以下，4-個以上）に比較検討すると, リンパ節転移個数 が 3 個以下の症例では両群間で有意差を認めなかったが, 4 個以上の症 例では $3 \mathrm{~F}$ 群が $2 \mathrm{~F}$ 群に比較して有意に良好であった.また再発形式では 両群間に有意差を認めなかった，手術時間，術中出血量，術後気管内挿 管日数, 反回神経麻瘦の発症率, 術後在院日数は $3 \mathrm{~F}$ 群で有意に多かっ た. 肺合併症の発症率, 縫合不全発症率, 気管切開施行率, 術後最高ビ リルビン値，致死率は 2 群間に有意差を認めなかった，術前後の体重比 (術前体重/術後体重), 術後のつかえ感やダンピング症状などの消化器 症状も 2 群間に有意差を認めなかった.【結語】 $2 \mathrm{~F}$ リンパ節郭清領は $3 \mathrm{~F}$ 郭清に比較して術後早期の合併症が多いが, QOL に差はみられなかっ た. 3 領域リンパ節郭清の適応は術前および術中所見でリンパ節転移個 数が 4 個以上の症例で施行する意義があると考えられた.

\section{PS01-07術前化学放射線療法施行進行胸部食道癌に対するリンパ 節郭清の意義}

山道啓吾, 浅井 晃, 道浦 拓, 小松優治, 羽原弘造, 馬殿徹也, 森 毅, 山中英治, 中根恭司

(関西医科大学第 2 外科)

【目的】術前化学放射線療法 (CRT) は進行食道癌に対する集学的治療と して切除率の向上や予後の改善が期待されている. しかし, 術前 CRT 後治瘾切除可能となっても，再発により早期に死亡する症例も少なくな い. 今回, 術前 CRT 後切除した進行胸部食道癌の治療成績から術前 CRT 後の根治手術の必要性について検討した.【方法】当科では食道扁平 上皮癌で術前画像診断上 $\mathrm{T} 3$ 以上で遠隔転移のない症例に対し, 術前 CRT を施行してきた. 2000 年 8 月までに術前 CRT 後治皟切除された進 行胸部食道癌 44 例 (T3：33 例, T4 $: 11$ 例) を対象に検討した.術前 CRT のレジメンは lineac $2 \mathrm{~Gy} \times 5 /$ 週 $\times 4$ 週，計 $40 \mathrm{~Gy}, 5-\mathrm{FU} 500 \mathrm{mg} /$ 日，連日持 続 $\times 4$ 週, CDDP $50 \mathrm{mg} \times 1 /$ 週 or $5 \mathrm{mg} /$ 日 $\times 5 /$ 週 $\times 3 \sim 4$ 週で, CRT 終了約 1 ケ月後に根治手術を行った。右開胸開腹でリンパ節郭清は上絴隔郭清 を伴った胸腹 2 領域郭清を基本とした. [結果】術前 CRT の治療効果は $\mathrm{NC}: 1$ 例, PR：39 例, CR : 4 例で奏効率は $97.7 \%$ であった. 切除標本 の病理組織学的治療効果は Grade1 $: 6$ 例, $2: 27$ 例, $3: 11$ 例であり, 臨 床的治療効果と必ずしも一致しなかった．また，44 例中，22 例で照射野 外のリンパ節転移が認められた. 再発は 22 例で認められ, 縦隔内再発が 6 例，リンパ節再発が 5 例で, 肝・肺転移など遠隔転移再発が 11 例と最 も多かった. 25 例が生存中であり， 5 生率は $42.6 \%$ であった. 臨床病理 学的因子别の生存分析 (Logrank 検定)においては，壁深達度，組織型， 腫瘍長径別には生存率の差はなかった. 一方, 組織学的治療効果 Grade 1 以下 $(\mathrm{P}=0.042)$, リンパ節転移 $\mathrm{pN} 2$ 以上 $(\mathrm{P}=0.0091)$, リンパ節転移 個数 3 個以上 $(\mathrm{P}=0.0002), \mathrm{y}$ 陽性 $(\mathrm{P}=0.040), \mathrm{v}$ 陽性 $(\mathrm{P}=0.0002)$ 症 例で有意に予後が不良であり, 手術単独治療成績と同様にリンパ節転移 が重要な予後因子となった.【結語】胸部進行食道癌に対する術前 CRT は壁外浸潤など腫瘍近傍の局所制御は期待できるが, 照射野外のリンパ 節転移や遠隔転移の制御は困難と考えられた。一般的に CRT 後の手術 は術後合併症を危惧しリンパ節郭清を控える傾向があるが, CRT 後も徹 底したリンパ節郭清の必要性が示唆された。

PS02-01 胃癌切除後逆流性食道炎の治療方針ーツムラ六君子湯の 術後早期投与効果を中心として

水野修吾, 岩田 真, 田端正己, 山際健太郎, 伊佐地秀司, 横井一, 川原田嘉文

(三重大学第一外科)

【目的】六君子湯は内科領域において様々な消化器症状である「虚証」に 対する有用性が報告されている. 今回, 外科領域, 特に胃癌切除後早期 の逆流性食道炎に対する六君子湯の臨床的効果を検討. (方法】逆流性食 道炎に対する治療効果として, 研究 1 : 術後 3 ヶ月以内に逆流症状を認 めた stage I, II 症例 7 例に対し，症状出現後六君子湯を $7.5 \mathrm{~g} /$ 日投与し， 逆流症状の推移・内視鏡所見 (ロサンゼルス分類)につき検討. 7 例は全 例根治度 A, B, 術式は幽門側胃切除, B-II 再建 5 例, 噴門側胃切除, 胃 全摘各 1 例. 次に, 逆流性食道炎の予防効果として, 研究 $2:$ Stage I, II (根治度 A, B) 症例 47 例を無作為に六君子湯投与 (26 例) と非投与 (21 例)の 2 群に分け, 投与群では経口椇取開始時に六君子湯を $7.5 \mathrm{~g} /$ 日投与 し, 逆流症状の出現率・内視鏡所見さらに術後平均在院日数を非投与群 と対比. 尚, 非投与群では薬剤に制限を加えず, 投与群ではシサプリド 等の消化管運動機能立進薬は一切使用せず，六君子湯のみの投与投与と した.【結果】研究 1 : 逆流症状 (胸焼け 7 例, 胃もたれ 6 例, 食欲不振 4 例，食事のつまり感 3 例，悪心・嘔吐 2 例) は投与後 2 週で 4 例に，さ らに 4 週では 1 例にまで滅少. また, 内視鏡所見は投与前は GradeB1 例，A6 例であったが，投与後 3 週では GradeA3 例, Grade04 例と改善 し, 投与 6 週では全例 Grade0 となった. 研究 $2:$ 術後 3 週目の逆流症状 出現例は非投与群の 6 例 $(28.6 \%)$ に比し投与群では 4 例 $(15.4 \%)$ と低 率であった. また, 症状出現例の内, 非投与群 6 例中 3 例に内視鏡所見 (GradeB1 例，A2 例) を認めたが，投与群では 4 例中有所見例は 1 例の みであった. さらに, 症状出現後, 非投与例では, 術後 6 週でも 4 例に 逆流症状が残存したのに対し，投与例では症状残存例は 1 例にすぎな かった. また, 術後平均在院日数は投与群は $41 \pm 5$ 日と, 非投与群 47 \pm 7 日に比べ, 短縮傾向にあった【はとめ】六君子湯早期投与は, 胃癌切 除後の逆流性食道炎の治療のみならず，予防の面でも有用であると考え られた. 
PS02-02胃食道逆流症に対する腹腔鏡下噴門形成術の適応と問題 症例に対する対応

柏木秀幸"，小村伸朗"，矢野文章"，石橋由朗"，青木照明"，阿部貞 信 ${ }^{2}$

(東京慈恵会医科大学外科"，森永胃腸科外科 ${ }^{21}$ )

【目的】胃食道逆流症に対する腹腔鏡下噴門形成術の治療成績より, その 適応と問題症例に対する対応を明らかにする.【対象と方法】1994 年 8 月より 2000 年 12 月までの間に教室ならびに関連病院にて, 胃食道逆流 症に対し腹腔鏡手術を行った 93 例を対象とした。男性 55 例，女性 38 例で，平均年㱓は 52.28 藏（18-81 歳）であった，混合型食道裂孔へル ニアを除き，原則的に逆流症状・食道炎の 1 年以上の持続を手術適応の 条件とした。術前後における内視鏡検査, 上部消化管造影検査, 24 時間

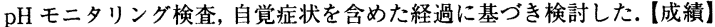
逆流防止の術式としては, 全周型の Nissen 法が 51 例で, 非全周型とし ては Toupet 法が 38 例，Dor 法が 3 例に行われていた。 また，非全周型 の噴門形成術例の 18 例 $(42.9 \%)$ に選択的近位迷走神経切離術が付加さ れ，6例（14.3\%）に幽門形成術が加えられていた. Nissen 法と Toupet 法の治療効果に差は見られなかったが, Nissen 法の 8 例 (15.7\%), Toupet 法の 3 例 $(7.9 \%)$ に中等度以上の嚾下困難が見られ, 最終的に前者 のうち 2 例は再手術を必要とした. 術前の薬物治療の反応性より, プロ トンポンプ阻害薬 (PPI) 抵抗例は 26 例 $(28.0 \%)$ を占めていた。 そして 術後の内視鏡所見, 自覚症状の改善は良好であったが, 24 時間 $\mathrm{pH}$ モニ タリング検查において高度逆流例の占める割合が高く，一部に改善不良 例が見られた，短食道合併例に対し，8例 $(8.6 \%)$ に絴隔内食道の授動 が行われ，2例 $(2.2 \%)$ に Collis-Nissen 法が行われたが，これらの症例 では良好な改善を示した. また, 高度逆流を伴う再発 1 が例に認められ たが，開腹下の Collis-Nissen 法により著明な改善が得られた.【結論】胃 食道逆流症に対する腹腔鏡下噴門形成術は良好な治療成績を示したが, 術前PPI 抵抗例にみられやすい高度酸逆流例において術後改善不良例 が見られた。このような症例では, 短食道の存在が重要となり, 縦隔内 食道の授動や Collis 胃形成術の付加が有用と考えられた.

PS02-03難治性逆流性食道炎にたいする腹腔鏡下逆流防手術 森 俊幸, 下位洋史, 阿部展次, 德原 真, 正木忠彦, 中島正暢, 杉山 政則，跡見 裕

(杏林大学第一外科)

【背景】PPI を用いた薬物治療に対する抵抗性により難治性食道炎は定義 され, 逆流防止手術の適応とも考えられている. 腹腔鏡下逆流防止手術 をおこなった難治性食道炎の臨床的特徴, また手術の短期・長期成績を 検討した.【対象・方法】難治性逆流性食道炎に対し腹腔鏡下逆流防止手 術を施行し 16 症例を対象とし, 術前術後の食道生理学的検查（内圧, $\mathrm{pH})$ ，内視鏡所見，短期長期の手術成績をを検討した.【結果]症例は男性 13 例, 女性 3 例 平均年齢：53.3歳 (19-81 歳)であり, floppy Nissen 法を 15 例に Guarner 法を 1 例に施行した. 手術時間は平均 3.8 時間 $(2.4$ $-6.6)$, 出血量は平均 $20.6 \mathrm{ml}(0-102)$ であった．開腹移行症例はなかっ た.手術により LES 静止压は平均 $12.2 \mathrm{mmHg}$ から $21.1 \mathrm{mmHg}$ へ上舁し, 長さも $1.9 \mathrm{~cm}$ から $2.9 \mathrm{~cm}$ と延長した. 術前 16 例中 13 例に食道体部運動 能の低下を認め，1例を除き手術による体部運動能の改善は認めなかっ た. 1 例では，術前無収縮であった食道体部運動能に著明な改善を認め た.また $24 \mathrm{hrpHHT}$ は術前平均 $36 \%$ が $3.9 \%$ に低下した. 食道内視鏡鏡 検査では，すでに隇酸療法を長期に施行されている症例が多かったが, 明らかな食道炎の改善を 9 例に認めた. 術前 Barrett 食道となっていた 症例では，手術によっても変化，消失を認めなかった，術後食事開始に 平均 3.4 日 $(1 \sim 11$ 日) を要し, 術後平均 12.4 日（7〜20日）で退院した. 術後観察期間平均 21.3 ヶ月（2 58 ケ月）で 16 例中 15 例で投薬が不要 となり, 1 例で間歇薬物療法を要した. 3 例に術後軽度のつかえ感が出現 したが 2 例では 1 月以内に消失した。持続性のつかえ感を 1 例に認めた が, 内視鏡検查で器質的な狭窄を証明し得なかった。術前食道裂孔へル ニアを 14 例で認めたが，1例をのぞき術後に再発を認めなかった.【結 論】難治例では臨床効果の高い腹腔鏡下逆流防止手術を考慮すべきであ ると考えられた. また Barrett 食道では, 粘膜の ablation など付加的处置 が必要であると考えた.
PS02-04逆流性食道炎の治療方針における腹腔鏡下手術の位置付 け 片田夏也, 桜本信一, 小林伸行, 嶋尾 仁, 菊池史朗, 榊原 譲, 柿田 章 (北里大学外科)

逆流性食道炎 (RE) はPPI を中心とする薬剤療法の中止による年間累積 再発率が $75 \sim 87 \%$ と極めて再発しやすい疾患である.これは REの本質 的な病態が過剩な胃酸分泌ではなく逆流防止機構の破綻にあることを 示している. 今回腹腔鏡下手術を施行した RE11 症例の手術成績を検討 し, $\mathrm{RE}$ の治療方針における腹腔鏡下手術の位置付けを考察する. 【症例 背景】男 8 例女 3 例, 小児 2 症例を除いた成人例の平均年齢は 62 歳. 全 例に食道裂孔へルニアを認め, 内視鏡 LA 分類では GradeB : 1 例, GradeC $: 7$ 例, GradeD : 2 例, 不明 : 1 例.【術式】臍上部に 12 or $5 \mathrm{~mm}$ $\mathrm{x} 1$ 本, 上腹部に $5 \mathrm{~mm} \times 4$ 本の trocar を挿入し, 食道周囲を剥離しつつへ ルニア囊を腹腔内に還納した. 食道後方で左右の横隔膜脚を縫合閉鎖し た。噴門形成術として 6 例に Nissen 法を施行した. wrappingに際して 食道内に $54 \sim 60 \mathrm{Fr}$. bougie を㨂入し calibration とした. 他の 5 例（1 例は開腹移行)には Toupet 法を施行した. 左右の wrap と食道前壁を 3 〜4 針ずつ縫合固定し partial wrap とした.【成績】術後観察期間は平均 15 ケ月（1 42 ケ月). Nissen 法施行の 1 例に持続性の dysphagia を認 め, Toupet 法施行の 1 例に酸逆流の再発を認めたが, 他の 9 例の経過は

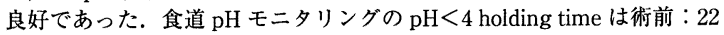
$\pm 21 \%$ (mean $\pm \mathrm{SD}$ ) と高值を示したが, 術後 1 例を除きほほ正常値まで 低下した.内圧検查でLES圧は術前：9.9 $2.9 \mathrm{mmHg}$ と低下していた が, 術後：19.5 $\pm 9.2 \mathrm{mmHg}$ と上昇した. 【結語】REに対する腹腔鏡下手術 の短期成績は良好であった. PPIによる REの長期維持療法が保険適応 となった現在，単に薬剤療法と手術療法の有効率を比較するのではな く, 手術は逆流防止機構の破綻を修正しうる点で, 薬剤療法より病態に 即した治療法であるである点を考慮すべきであると考えられた．以上よ り, 手術適応を薬剤療法抵抗症例に限定せずに, 将来的には手術療法は $\mathrm{RE}$ の維持療法としての選択肢のひとつであると位置付けるのが適当で あると考えられた。

PS02-05 80 歳以上高齢者の逆流性食道炎に対する腹腔鏡下噴門 形成術の有用性

井谷史嗣, 金 仁洙, 宇田憲司, 室 雅彦, 金子晃久, 佐々木寛, 渡邀 和彦, 石井辰明, 成末允勇

(福山市市民病院外科)

80 歳以上高齢者の逆流性食道炎に対する腹腔鏡下噴門形成術の有効性, 安全性を検討するために，当院にて 1997 年 5 月から 2001 年 1 月の間に 腹腔鏡下噴門形成術を受けた 27 例の逆流性食道炎患者を 80 歳以上群 6 例 $(80-88$ 歳, 平均 83.7 歳) と 80 歳未満群 21 例 (59-79, 歳, 平均 68.5 歳) とに分けて, 手術時間, 術後在院日数, 合併症, 短期予後につき比 較検討した. 術前の American Society of Anesthesiologist（ASA）によ る score は 80 歳以上群 $2.50 \pm 0.22$ が 80 歳未満群 $1.71 \pm 0.56$ に比較して 有意に高かった $(\mathrm{p}<0.01)$. Los Angeles 分類による食道炎の grade 別症 例数は, 80 歳以上群が $\mathrm{A}: 1$ 例, C $: 4$ 例, D : 1 例で 80 藏未満群が A : 1 例, B : 5 例, C : 6 例, D : 9 例であり, 80 歳未満群に重症例が多い傾 向にあった。一方, 混合型ヘルニアは 80 歳以上群に 2 例 $(33.3 \%), 80$ 歳未満群に 2 例 $(9.5 \%)$ 認められ，80歳以上群に多い傾向にあった．標 準術式として 54-60Fr ブジー挿入下での腹腔鏡下 floppy Nissen 法を 施行した. 手術時間, 出血量, 経口摄取開始日および術後在院日数は 80 歳以上群で $146.8 \pm 26.9$ 分, $130.0 \pm 158.6 \mathrm{~g}, 1.8 \pm 1.6$ 術後病日および 10.0 \pm 2.6 日であったのに対し 80 歳未満群ではそれぞれ $116.2 \pm 39.7$ 分, 65.7 $\pm 73.6 \mathrm{~g}, 1.1 \pm 0.3$ 術後病日および $7.9 \pm 2.3$ 日であり, いずれも両群間に有 意差は認められなかった。両群ともに術死，腹腔鏡下手術からの開腹移 行は認められなかった，手術に起因する入院中合併症は 80 歳以上群に は認められず, 80 歳未満群に左側気胸, 皮下血腫を各 1 例認めたがいず れも軽度であった. 短期予後としては 80 歳以上群で症状の消失が 4 例, 軽快が 1 例（有効率 $83.3 \%$ ）に，80 歳未満群でぞれぞれ 16 例および 3 例（有効率 $90.5 \%$ ) に認められた. 再手術を要したのは 80 歳以上群で術 後傍食道裂孔へルニア该頓の 1 例, 80 歳未満群で高度の食道炎再発 2 例のうち 1 例であった。.以上より 80 歳以上高齢者の逆流性食道炎に対 する腹腔鏡下噴門形成術の手術成績は 80 歳未满患者の手術成績に比較 して遜色なく，全身状態を評価した上で積極的に手術を考慮すべきであ ると考えられた. 
PS03-01当科における幽門温存胃切除術の成績とリンパ節転移か らみた適応の拡大の可能性の検討

野村幸世, 山口浩和, 清水伸幸, 下山省二, 真船健一, 上西紀夫 (東京大学胃・食道外科)

【目的】当科における幽門温存胃切除術施行症例を検討し, さらなる適応 の拡大の可能性を検討した.【方法】当科においては早期癌で, 幽門輪よ り病変までの距離が $4.5 \mathrm{~cm}$ 以上, 口側残胃の大きさがもとの胃の $1 / 5$ 以上残存可能である症例を幽門温存胃切除術の適応としてきた. 術式と しては右胃大網動脈根部より $2 \mathrm{~cm}$ 以内に幽門下動脈が認められる場合 はそれを温存, No.6 リンパ節は動脈より剥離郭清, 右胃動脈は根部にて 処理, 肛側胃は幽門輪より $1.5-2.0 \mathrm{~cm}$ 残す方式をとっている. 1993 年 10 月より 1999 年までに幽門温存胃切除術を施行した症例は 48 例あった。 この 48 例の病変の深達度, リンパ節転移, 子後を検討した. また, 適応 の拡大を目し, 当科における M 領域深達度 MP 胃癌のリンパ節転移状 況を検討した. 【成績】 48 例のうち深達度 M32 例, SM13 例, MP1 例, SS 1 例，SE1 例であった. リンパ節転移症例は 4 例であった．そのうち 2 例は $\mathrm{n} 2$ であった，術後 5 年に達する症例は 17 例であるが, その後の症 例も含め, 全例無再発生存中である. 1976 年から 1999 年に当科で切除さ れた M 領域(他の領域にまたがらない) MP 胃癌は 21 例であった。この うち 13 例 $(62 \%)$ が n0, 7 例 $(33 \%)$ が 1,1 例 $(5 \%)$ がn2であった. リンパ節転移先はNo.1, 3,4d, 6,7 に分布した. No. 1 に転移を有する症例 は n1 の 1 例であり，腫瘍径 $7 \mathrm{~cm}$ ，組織型は por で潰瘍を有した． No. 6 に転移を有したのは $\mathrm{n} 1$ の 1 例であったが, 組織型は sig, 体中下部大弯 に位置する径 $2.5 \mathrm{~cm}$ の腫場であった.【結論】当科における幽門温存胃切 除術においては通常の D2 郭清に比較してやや郭清度が劣るのは No. 1, 6 であると考えられる. 現在の適応では充分な成績が得られており，症例 を選べば, 適応の拡大も可能である. M 領域, MP 癌に限れば, 腫瘍径 が大きいもの, 未分化型, さらにNo. 6 リンパ節転移を除外するのであれ ば，大弯の未分化病変を除けば，幽門温存胃切除術の適応となると考え られた. PS03-02 幽門温存胃切除術後遠隔期症例における胃幽門十二指晹
空腸運動の解析

西川和宏"，弓場健義"，川原央好"，西田俊朗"，井上善文"，北川 透"), 打越史洋"，伊藤壽記"”，松田 睴"

(大阪大学大学院医学系研究科 $\mathrm{E} 1$ 機能制御外科学 ${ }^{1}$, 大阪大学小児外 科 ${ }^{2}$ )

【目的】幽門温存胃切除術 (PPG) 術後の上部消化管運動機能は未だ明ら かでない.PPG 術後症例における消化管運動を, 幽門側胃切除術 (DG) 術 後症例と比較して検討する.【方法】対象は早期胃癌術前症例 7 例 (P 群), DG 症例 17 例（DG 群)，PPG 症例 14 例（PPG 群）とした。手術は DG では D2 郭清を行い, PPG では\#5リンパ節郭清を省略し，迷走神経肝枝 ・幽門枝を温存した. いずれも Billroth I 法再建を行った．以下の項目に ついて検討した. 1) 臨床症状：体重変化, 胃内容停滞症状, ダンピング 症状のアンケート調查 2) 胃排出 dual scintigraphy：99mTc sulfur colloid を混ぜた固形食と 111In-DTPA を混ぜた液体食の胃内残存率を 120 分間 $\gamma$ カメラにて計測 3 ) 胃幽門十二指腸内圧検查 (DG 群を除く)：脂 肪乳棛の十二指腸内投与後と Erythromycin（EM）静脈投与後の内圧を sleeve catheter を用いて持続測定 4) 胃十二指腸空腸内圧検查：空腹期 6 時間, EM 投与後 1 時間の持続内圧測定 【結果】1) 術前比体重変化は DG 群 $91 \pm 9 \%$, PPG 群 $93 \pm 4 \%$ で有意差を認めなかった. 胃内容停滞症 状は DG 群 33\%,PPG 群 $58 \%$ で, ダンピング症状は DG 群にのみ $33 \%$ に 認められた．2）液相胃排出は P 群に比し DG 群と PPG 群は共に 30 分後 まで促進していた．固体相胃排出はDG 群は 60 分後まで促進し, PPG 群は 120 分後で遅延していた．3）胃幽門十二指腸内圧検查：P 群同様 PPG 群においても isolated pyloric pressure wave（IPPW）を認め, EM 投与後に Migrating Motor Complex (MMC) phase III 類似の運動を認め た. 4) 胃十二指腸空腸内圧検査：DG 群，PPG 群ともに phase III を認め たが, 伝達途絶などの異常は DG 群で多かった.【総括】PPG 症例は, 臨床 症状では胃内容停滞症状が多く, ダンピング症状は少ない傾向であった。 固体相胃排出の遅延が PPG 術後の胃内容停滞症状の原因と思われた. PPG で温存された幽門にも IPPW や MMC phase III 類似の運動を認め, 運動機能が保たれていると考えられた．PPG 症例の空腹期胃十二指腸空 腸運動は, DG 症例と異なったパターンを示した。
PS03-03幽門保存胃切除術 (PPG) の遠隔成績からみた適応と限界 山田行重, 藤本平祐, 上野正闘, 高山智玟, 鎌田喜代志, 内藤彰彦, 蜂 須賀崇, 平尾周也, 中島祥介

(奈良県立医科大学第 1 外科)

【目的】教室では 1989 年より $\mathrm{M}$ 領域の早期胃癌に対して幽門洞部を幽 門輪より $1.5 \mathrm{~cm}$ 温存する幽門保存胃切除術（PPG）を行ってきた。本術 式では幽門機能が温存されることにより, 食物の十二指腸への急速排出 や十二指腸液の逆流が防止され，さらに貯留能や消化吸収能が維持さ れ，種々の胃切除後障害が予防できると考えられる. 今回, PPGの遠隔 成績からその適応と限界について検討した. 【方法】1989 年より術前深達 度 $\mathrm{M}$ と診断された $\mathrm{M}$ 領域の癌を手術適応としていた. しかし, D2 郭清 が可能であることや，占拠部位別，深達度別リンパ節転移の検討及び EUSによる深達度診断の向上により，1993 年から, 深達度 SM 症例や, $\mathrm{L}$ 領域でも $\mathrm{AW}$ が幽門輪より $3.5 \mathrm{~cm}$ 以上離れている症例には $\mathrm{PPG}$ を採 用している. 今回, 10 年間にPPG を施行した 91 例について遠隔成績の 観点より Billroth I 法 (B-I) と比較検討した.【成績】術後合併症は, イレ ウスを 1 例に認めたが保存的療法により改善した．退院後の体重の変化 は, B-I より PPGの方が体重滅少は少なく, 術後 2 年で退院時の体重に ほほ回復していた，ダンピング症候群の発生頻度は, PPGで $2.5 \%$, BI で $15.0 \%$ と有意に PPG で低頻度であった. 胃内視鏡検査による残胃の 発赤の状態を観察すると, 発赤の程度が吻合から体部にまで及ぶ程度の ひどいものは, B-I の $18 \%$ に比べPPGではわずかに $2 \%$ であり PPG で良好な結果であった. 最長のもので術後 11 年経過しているが, 再発を きたした症例はなかった.【まとめ】近年, 縮小手術や機能温存手術など 患者の QOL が得られる術式の必要性が求められるようになってきた。 そこで幽門側胃切除術 (B-I) に代わる術式として，1989年より早期胃癌 に対してPPG を行っている. 今回の検討から, 術後合併症についてはBI 症例と遴色のない成績が得られており，また郭清に関しても根治性を 失う心配はなく, PPGにおいても通常の幽門側胃切除と同様, 安全かつ 標準的な術式であると考えられる. 今後は早期胃癌のみならず, $\mathrm{AW}$ が幽門輪より $3.5 \mathrm{~cm}$ 以上離れている限局型進行胃癌にも $\mathrm{PPG}$ の適応拡 大が可能と考える.

PS03-04幽門保存胃切除術の遠隔成績からみた適応と限界 石後岡正弘，河島秀昭，原 隆志，樫山基矢，高梨節二，後藤 剛，畠 山広已, 山崎左雪, 細川譽至雄

(勤医協中央病院外科)

[目的]幽門保存胃切除術 (以下 PPG) 施行症例の臨床病理学的所見と遠 隔成績から PPGの適応と限界について検討した. [方法]当科において 1991 年開始から 1999 年までに施行された 146 例を対象とし, 深達度,リ ンパ節転移と 5 年生存率, 再発, 術後 1 年経過時でのアンケート調査に よる後遺障害について検討し，さらに幽門側胃切除例 (以下 DG) と比較 検討した。 なお PPGの適応は術前 M あるいは MLの早期癌で肍門側切 離端が幽門輪より $2 \mathrm{~cm}$ 以上確保できる症例とした. 手術術式は幽門下動 脈を温存し迷走神経幽門枝は非温存とした M 癌は D1, SM 癌は D2 郭清 を原則とした. [結果] M 癌 84 例, SM48 例, MP4 例, SS6 例, SE1 例, 根治度 C3 例であった. M 癌はすべて N0 で再発はなかったが 7 例の他 病死を認め 5 年生存率は $88 \%(\mathrm{DG} 90 \%)$ であった. SM 癌では N 陽性 8 例 $(\mathrm{N} 1: 5, \mathrm{~N} 2: 3)$ であったが, 再発はなく 3 例の他病死を認め 5 生率 は 86\%(DG87\%)であった，MP 癌は 4 例のみですべて N0であったが, 全例無再発生存中であった. SS 癌は 6 例のみで N 陽性は 2 例であった が, 全例無再発生存中であった. 術後 1 年経過時アンケート調査にて回 答の得られた早期癌 71 例と同時期に施行された DG120 例と比較検討 した. ダンピング症状は有意にPPG で少なかったが, 食事搷取量や体重 の回復では差を認めなかった。早期に見られた残胃のうっ滞症状は認め られず，内視鏡では残胃に残渣を認める症例もあったが，残胃炎は少な かった。な打残胃癌 (噴門側)を 1 例 (32 ヶ月後)に認めた. [結語] PPG の遠隔成績は良好であった. PPGは根治性と機能温存を兼ね備えた手術 であり，本術式により M または ML 領域のすべての早期癌が適応とな る. 進行癌はまだ症例数が少ないが, M または ML 領域の No あるいは N1 症例に対して D2により適応拡大が可能と考えられた. 
PS03-05腹腔鏡補助下胃切除術における幽門輪温存と非温存の残 胃運動能評価

漆原 貫, 黒田義則, 倉西文仁, 石山宏平, 徳本憲昭, 志々田将幸, 田 原裕之

\section{(厚生連尾道総合病院)}

【目的】早期胃癌に腹腔鏡補助下胃切除術を適応し腫場占扯部位が $\mathrm{L}$ 領 域で幽門輪非温存胃切除術 (以下 LADG), M 領域であれば機能温存目的 で幽門輪温存胃切除術（以下 LAPPG）を選択している. MRI 法と腹部 超音波法 (以下 US 法) を用いて術後 1 ヶ月目と 1 年目の残胃運動能と十 二指腸胃逆流を測定し検討した. 【方法】平成 10 年 1 月から平成 12 年 11 月までに腹腔鏡補助下幽門側胃切除術 40 例を施行した。 そのうち早期 胃癌 cStageIA で LADG を施行した 16 例 (平均年齢 67 才，男性 10 例, 女性 6 例)，LAPPG を施行した 18 例 (平均年齢 68 才, 男性 9 例, 女性 9 例）について術後 1 ケ月目, さらに 1 年経過した LADG8 例, LAPPG 10 例には 1 年目に MRI 法で排泄時間 (T1/2), 運動能指数 Motility in$\operatorname{dex}($ 以下 M. I. ) と US 法で逆流回数と強度より逆流指数（以下 R. I.） を求め比較した. [結果】 1 ケ月目の T $1 / 2$ は LAPPG $133 \pm 54.2$ 分に対し LADG97.1 588.6 分で有意に LADG が排泄早期であった $(\mathrm{p}<0.05) . M$ I. は LAPPG5.3 \pm 1.9 であり LADG2.3 1.3 に比較し有意に残胃運動能が 優れていた $(\mathrm{P}<0.001)$. R. I. に関しては LAPPG6.00 4.23 は LADG21.0 \pm 12.8 に比較し有意に逆流が少なかった $(\mathrm{p}<0.001) .1$ 年目の $\mathrm{T} 1 / 2$ : LAPPG $132 \pm 52.3$ 分, LADG87.9 550.7 分は 1 力月目と同様に LADG が 排泄早期であった $(\mathrm{p}<0.05)$. M. I. は LAPPG6.1 1.5 は LADG3.2 \pm 1.5 に比較し 1 力月目と同様に優れていた $(\mathrm{p}<0.01)$. R. I. は LAPPG5.56

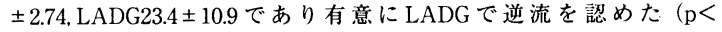
0.001).【結語】LAPPG は LADG に比較し, すでに 1 力月目から胃排泄, 残胃運動能の面から優れ, さらに十二指腸胃逆流が少ない利点を備え 1 年目においても同様の結果が存続した.

\section{PS03-06幽門温存胃切除術は機能温存面から患者の満足を得られ たか?}

平塚正弘, 宮代 勲, 石川 治, 古河 洋, 山田晃正, 村田幸平, 土岐 祐一郎, 大東弘明, 龟山雅男, 佐々木洋, 甲 利幸, 今岡真義

(大阪府立成人病七ンター外科)

【目的】幽門温存胃切除術は, 主として胃中部の早期胃癌に対して機能温 存を目的として行われてきた. 客観的な食物残渣の量および胆石生成の 有無と主観的な症状などの遠隔成績から, その適応と限界について検討 した.【方法】1992 年〜1998 年に 72 例の胃癌症例に幽門温存胃切除術を 施行した。組織学的癌深達度は $\mathrm{m}$ が 54 例, $\mathrm{sm}$ が 17 例, $\mathrm{mp}$ が 1 例で, リンパ節転移は $\mathrm{n} 0$ が 71 例で $\mathrm{n} 1$ が 1 例であった。確認した迷走神経温 存症例は, 肝枝のみ 3 例, 腹腔枝のみ 2 例, 肝枝 + 腹腔枝 28 例, 肝枝 + 腹腔枝 + 前上枝 8 例, 肝枝 +前上枝 1 例で, 幹迷切 2 例であった. 遠隔 成績の客観的評価として, 胃内視鏡検査により残渣の量を 1. なし, 2. 少 量〜中等量, 3. 大量に分類し, 腹部超音波検査により胆石の有無を検討 した. 主観的評価として 1995 年までの症例に対して, アンケートにより 胸やけと胸がつかえるような感じについて，それぞれ 1. よくする，2.た まにする, 3. ほとんどしない, 4. 全くしない, の質問を行った.【結果】1. 胃内視鏡検查による残渣の量：大量の残渣がみられた症例は, 1 年目 29 $\%, 2$ 年目 $20 \%, 3$ 年目 $34 \%, 4$ 年目 $11 \%, 5$ 年目 $25 \%$ で, 経時的な改 善は認められず, 年数を経てさらに增加する症例もみられた. 2. 全経過 で残渣の最高値を各症例に評価すれば, 残渣なしが $34 \%$, 少量〜中等量 が $14 \%$, 大量が $51 \%$ で，機能温存の効果は残念ながら認められなかっ た. 3. アンケートの結果 1. よくする，2. たまにするを合わせた症例は, 胸やけは $38 \%$,胸がつかえるような感じは $40 \%$ にみられ，決して良好と は言えない結果であった. 5. 手術時までに胆摘既往などを除いた 5 年経 過 37 例中，胃切除後胆石は 2 例 $(5 \%)$ にのみ確認され，従来の幽門側 胃切除の $25 \%$ に比べて低率であった【まとめ】胃癌に対する幽門温存 胃切除術は, 術後胆石症の生成抑制には寄与したが, 客観的には, 半数 の症例において大量の食物残渣がみられ，主観的には胸がつかえる感じ を訴える症例が多く，機能温存の目的を十分には果たせなかった. 今後， 局所切除の適応拡大の研究が望まれる.
PS04-01 胃癌に対する各種再建術における術後の細菌学的検討 関田吉久", 竹下公矢", 海山智隆"), 谷 雅夫", 齋藤直也", 岩井武 尚", 千田俊雄3)，岡村 登3"

(東京医科歯科大学外科 (食道 - 胃外科) ", 東京医科歯科大学光学医療 診療部 ${ }^{21}$, 東京医科歯科大学保唤衛生学科 ${ }^{31}$ )

く目的〉パウチ作製を主体とした胃癌術後の粘膜細菌丵の傾向や特徴 を把握するために, 各種再建術における再建臟器粘膜の細菌丵を検出, 比較検討した. <対象と方法>最近の胃痹切除症例 31 例で, 性別は男性 17 例, 女性 14 例, 平均年齢 61 歳であった. 術式別内訳は, 胃切 B-I, 胃 切 B-II で 7 例, PPG8 例, 全摘 R-Y2 例の計 17 例, 全摘空腸パウチ間置, 全摘空腸パウチ R-Y で 6 例, 噴切空腸パウチ間置 8 例の計 14 例であっ た. 滅菌鉗子を用い, 内視鏡下で 3 点生検した. 生検組織は輸送培地に 入れ水冷下に輸送し, 2 時間以内に培地に接種した. 検体の重量を測定 し，10-2,10-3 及び $10-4$ 倍希釈液を作製した. 培養は各部位ごとに 6 枚の選択, 非選択培地に接種した. コロニー形態, グラム染色より菌群 レベルを同定を, コロニーをカウントして, 粘膜 $1 \mathrm{~g}$ 当たりの菌数を対数 で表示した. <結果>1)すべての術式で合わせて 10 種類の菌群を認め, 部位別では残胃でその 10 菌群をすべて認めた．2) 胃切 B-I の残胃 (検出 率 $80 \%$, 平均菌数 5.5 ) と PPG の残胃（検出率 $63 \%$, 平均菌数 6.4) 及び 十二指腸（検出率 $25 \%$, 平均菌数 4.5) に H. pylori を認め, その平均菌 数は他の菌に比べて多い傾向にあった．3)空腸パウチ再建例では, 採取 した全ての部位に, H. pylori を認めなかった. 4) 空腸パウチ再建では, 他の術式に比べて食道, パウチなどでの総菌数が多く, パウチ内での嫌 気性菌の検出率は $86 \%$, 平均菌数 6.1 と高かった. 〈考察>1) 空腸パウ 千再建では採取した全ての部位で総菌数が多く，嫌気性菌の割合が高い 傾向にあり, H. pylori を認めなかった。一方, 胃切 B-I, PPG 群では, H. pylori 検出率, 総菌数が高い傾向にあり, これらの事実は, 各種術式別に 細菌丵の動態で著明な差異を示しており, 胆汁や嫌気性菌は H. pylori の発育に不利な環境をあたえる可能性が示唆された．2) パウチを主体 とした胃癌術後において, 術後再建臟器内の粘膜細菌叢の検索は, 臨床 症状, 運動機能, 内視鏡所見などに加えた機能評価の 1 因子として QOL の向上に寄与できる可能性が示唆された.

PS04-02噴門側胃切除空腸パウチ間置再建法の成績と問題点 仙丸直人”, 森田高行", 藤田美芳", 宮坂祐司"), 高田 実", 高橋 亮"，加藤紘之 ${ }^{21}$

(北海道消化器科病院" , 北海道大学腫瘍外科 ${ }^{2)}$ )

【目的】空腸パウチ間置再建法（JPI 法）の成績を以前に行っていた空腸 間置再建法 (JI 法) と比較するとともに, JPI 法の問題点を検討した. 【方 法】 1 . JI 群 (1989 年 3 月から 96 年 3 月) 13 例（男女比 8/5） と JPI 群 (96 年 8 月から 2001 年 1 月) 31 例 (男女比 $24 / 7$ ) を対象とし, 手術時間, 術後合併症, 術後 1 年目の体重, アンケートと問診により術後 6 ヶ月以 上経過し回答の得られた JI 群 13 例, JPI 群 21 例につき術後の症状, 術 前と比較した 1 回食事量について比較した. 2.JPI 法の問題点について パウチの拡張, パウチのうっ滞, 逆流につき, パウチの長さから検討し た.【結果】1. 手術時間は JI 群 298 分, JPI 群 274 分と差はなかった。術 後合併症は JI 群は縫合不全 1 例, 創感染 1 例, 吻合部狭窄 2 例であり, JPI 群は MRSA 感染 2 例, 肺塞栓 1 例，イレウス 1 例，胆汁漏 1 例，吻 合部潰瘍 2 例, パウチの出血 1 例, 吻合部狭窄 4 例, で合併症の発生率 は JI 群 $31.8 \%$, JPI 群 $32.3 \%$ と差を認めなかった。術後 1 年目の体重は JI 群が術前比 $83.8 \%$, JPI 群 $89.9 \%$ であり JPI 群で有意に $(\mathrm{p}<0.05)$ 回 復が良好であった。術後の症状は胸焼けはJI 群 7.7\%,JPI 群 33\% と JPI 群に多く認められた。早期ダンピング症状は JI 群 $38 \%$, JPI 群 $9.5 \%$ で JI 群に多い傾向にあった。腹痛はJI 群 $54 \%$, JPI 群 $9.5 \%$, 嘔吐はJI 群 69\%,JPI 群 9.5\%，つかえ感およびもたれ感はJI 群 77\%, JPI 群 38 \%であり JI 群に有意に $(\mathrm{p}<0.05)$ 多く認められた. 1 回食事量はJI群が 術前比 $66 \%$, JPI 群が $77 \%$ と JPI 群が有意に多かった $(\mathrm{p}<0.05)$ ．2. 術 後 6 ケ月以降造影を施行された JPI 群 22 例中 6 例にパウチの拡張を認 めた．パウチ長が $18 〜 20 \mathrm{~cm}$ (LP) では $5 / 16,10 〜 16 \mathrm{~cm}$ （SP）では $1 / 6$ に拡張を認めた.うっ滞症状は LP では $7 / 15$, SP では $1 / 6$ に認められた。 食道への逆流は LP では $6 / 15, \mathrm{SP}$ では $1 / 6$ に認められた.【まとめ】 JPI 法は体重の回復が良好で, 1 回の食事掑取量が多く, 腹痛, 嘔吐, つかえ 感が少ない点でJI 法より有意に優れていた. その反面, 胸焼けの頻度が 比較的高く逆流予防の対策が必要であると思われた. $20 \mathrm{~cm}$ 長のパウチ はうっ滞，拡張を起こしやすく $10 〜 16 \mathrm{~cm}$ が適当と思われた。 
PS04-03

床的評価

安永正浩, 田平洋一, 中野敢友, 飯田伸一, 一丸孝之, 永本展英, 坂口 智則, 福永剛隆, 松下尚之, 平岡武久, 川筋道雄

(熊本大学第 1 外科)

【目的】幽門側胃切除後における空腸 Pouch 間置再建術（JPI）の有用性 を検討した.【方法】1996 年から 2000 年の根治的幽門側胃切除後の再建 として JPI 施行 10 例と，同時期に同様の手術適応で行った Billroth I 法 (BI) 施行群 10 例について手術時間, 出血量, 在院日数, 入院コスト, 周術期合併症の発現と術後の食事摄取量, 体重増加, ダンピング症状, つかえ感, 胸焼け, 腹満感の出現について検討した.【結果】JPI 群の背景 因子は年齢 63.2 歳, 男 6 女 4 , 術前体重 $53.2 \mathrm{~kg}$, 術前 BMI 21.4, 病理学的 進行度 IA 6 例 IB 3 例 II 1 例で, BI 群は, 年齢 66.9 歳, 男 6 女 4 , 術前体 重 $53.5 \mathrm{~kg}$, 術前 BMI 22.2, 病理学的進行度 IA 6 例 II 4 例でいずれも有意 差を認めなかった. JPI 群の手術時間 356.5 分, 出血量 $570.5 \mathrm{~g}$, 在院日数 51.9 日, 保険請求費 204903 点に対し BI 群は手術時間 298.8 分, 出血量 $708.4 \mathrm{~g}$, 在院日数 62.7 日, 保険請求費 211319 点で手術時間が $\mathrm{p}=0.05$ でJPI 群が長い傾向を認めたが, 出血量, 在院日数に有意差を認めな かった．また，JPI 群で上昇が奬念された入院コストは総額で比較する と, BI 群とほほ同額で有意差を認めなかった. 合併症は JPI 群で術後早 期イレウス 1 例認めた. 食事摄取量（術前比）は JPI 群が術後 3-6 ケ月 後で $81 \%$, 術後 1 年後で $86 \%$ に対し, BI 群は術後 3-6 ケ月後で $59 \%$, 術後 1 年後で $63 \%$ と各々 $\mathrm{p}<0.005, \mathrm{p}<0.05$ で有意差を認めた. 体重 (術 前比）はJPI 群が術後 3-6 ケ後で $93.7 \%$, 術後 1 年後で $94.1 \%$ に対 L, BI 群は術後 3-6 ケ月後で $86.7 \%$, 術後 1 年後で $85.9 \%$ でいずれの 期間も $\mathrm{p}<0.05$ で有意差を認めた。ダンピング症状を $\mathrm{BI}$ 群で 2 例認め た.つかえ感は両群とも 2 例認めた. 胸焼けは BI 群で 1 例認めた. 腹満 感は JPI 群で 1 例認めた。 いずれの症状とも出現率に両群間で有意差を 認めなかった.【総括】幽門側胃切除後空腸 Pouch 間置再建術は Billroth I 法と比べ, 手術時間が長くなる傾向にあるが, 周術期合併症, 在院日数, 入院コストに差はなく，術後早期より食事掑取量と体重の改善を認め, ダンピング症状もなく栄盖代謝の面で優れた再建術式であるといえる。

PS04-04 胃全摘空腸パウチ間置術後の消化管機能評価

西田俊朗, 西川和宏, 弓場健義, 北川 透, 井上善文, 伊藤壽記, 松田 睴

(大阪大学大学院医学系研究科 $\mathrm{E} 1$ 機能制御外科学)

【目的】胃全摘後の障害として食事摄取量の低下と逆流性食道炎がある. 近年胃全摘の再建に空腸パウチを用いることが再認識されつつある。今 回, 胃全摘空腸パウチ間置術後の消化管機能を Roux-en Y 再建術と比較 し，患者愁訴，食道への胆汁逆流，アルカリ逆流，排出シンチグラムか ら検討した.【方法】根治術を行い得た胃癌症例で，他に合併症を有しな い症例を対象とした. 対象は $14 \mathrm{~cm}$ の空腸パウチを付加した噴門形成付 加パウチ間置胃全摘術（TP）15 例，胃全摘 Roux-en Y 再建術（TY）15 例，幽門側胃切除術 (DG) 11 例である. 術後一年目にアンケート調査, 食道内 24 時間 $\mathrm{pH} モ ニ タ ー(>\mathrm{pH} 7$ の時間の割合), Bilitec 2000 モ二 夕ー (吸光度 $>0.14$ 単位の時間の割合)，食道内視鏡，胃 (パウチ) 排出 シンチグラムを行い評価した.【結果】術後一年目の体重は TP・TY それ ぞれ理想体重比 $92 \% \cdot 87 \%$ で，一日食事椇取量は TP・TY それぞれ術 前の $90 \% \cdot 63 \%$ と TP で良好であった. ダンピング症状は TP, TY とも 1 例ずつ認め，胸やけもそれぞれ 2 例づつ認めた。 食道炎は LA 分類で Grade C 1 例を TPに, Grade A と B 各 1 例を TY に認めた。,ビリルビン 逆流の時間割合は TPで $18 \%$, TY で $31 \%$ ，アルカリ逆流の時間割合は TP で $25 \%$, TY で $34 \%$ と TP で逆流が少ない傾向を認めた. TP の消化 管排出シンチグラムは，食飭が同様な経路をとる DG と比較検討した が, 食後 1 時間目の $\mathrm{TP} \cdot \mathrm{DG} \cdot$ 一れぞれの術前・健常人の胃(パウチ)内 残存シンチ量は $74 \cdot 19 \cdot 44 \cdot 34 \% ， 2$ 時間值はそれぞれ $64 \cdot 10 \cdot 10 \cdot 6$

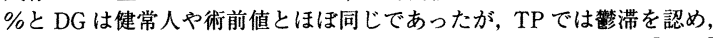
術後愁訴を調べても TP の約半数に食後の胃もたれ感を認めた.【総括】 以上, 胃全摘後の空腸パウチ間置は食事摂取量の増加と体重の維持, 術 後食道炎防御には Roux-en Y 同等或いはそれ以上に有用であったが，パ

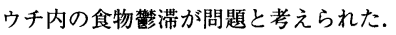

PS04-05 胃全摘術後空腸 pouch 間置法の評価

寺島雅典，高金明典，阿部 藁, 清水光昭, 荒谷宗充, 米澤仁志, 入野 田崇, 大山健一, 稲葉 亨, 藤原久貴, 斎藤和好

(岩手医科大学第 1 外科)

（目的）胃全摘術後の再建方法としての空腸 pouch 間置術（JPI）の有用 性と問題点について検索する目的で, 術後食物貯留能, 体重ならびに術 後愁訴に関て通常の空腸間置術 (JI) と比較すると共に, JPIにおける至 適 pouch 長について検討した. (対象と方法) 対象は 1996 年 1 月から 2001 年 2 月までの間に当科において胃全摘術を施行され, JI で再建され た 9 例（JI 群）および JPI で再建された 12 例（JPI 群）とした。手術術 式は，原則として全䐙温存 D2 郭清を伴う胃全摘術で，再建法として JI 群では $40 \mathrm{~cm}$ の有茎空腸を食道十二指腸間に間置した.JPI 群では左側 に順蠕動腸管がくるように近位側に約 $20 \sim 15 \mathrm{~cm}$ の pouch を形成し，10 $\mathrm{cm}$ の輸出脚と共に食道十二指腸間に間置した，両群において術後 6 ケ 月における半固形食による排泄シンチにより食物貯留能を測定した. ま た，アンケートにより術後愁訴について調査した（結果）両群で術後出 血, 縫合不全等の合併症を認めなかった．排泄試験では，間置空腸から 十二指腸への排泄時間の半隇期が, JI 群が $7.2 \pm 7.5$ 分であったのに対 し, JPI 群では $62.5 \pm 23.1$ 分と有意な $(\mathrm{p}=0.0281)$ 食物䝪留能の増加が認 められた.JPI 群において pouch 長と半隇期との関連について検討する と, pouch 長が $15 \mathrm{~cm}$ を越える症例で有意に半減期が延長していた（ $=0.0388$ ). 術後体重の推移では, 術後 6 ケ月で JPI 群において体重の回 復が良好であった。術後愁訴としてはJI 群で後期ダンピング症状を 2 例に認めたが, JPI 群では逆流性食道炎, ダンピング症状は認められな かった. 但し JPI 群において排泄時間の長い症例で食後の上腹部不快 感，嘔吐が認められた（結語）空腸 pouch 間置術は，従来の空腸間置術 に比し食物貯留能に優れ，胃全摘術後のQOL 改善に優れた方法である と思われた. しかし長すぎる pouch は食物の停滞による愁訴の原因とな るため, $15 \mathrm{~cm}$ 以下の pouch が適当と思われた.

PS04-06 胃切除後パウチ間置再建術の問題点とその対策 池田正視"，上田哲郎"2，山形邦嘉"，城原直樹"，馬越俊輔"，伊東俊 秀", 大橋佳弘", 高塚 純", 柴 忠明", 山口宗之"

(東邦大学第 2 外科 ${ }^{11}$, 東邦大学佐倉外科 ${ }^{21}$ )

【目的】パウチ間圈再建術を施行した 55 例（T 群：胃全摘 33 例，D群 : 幽門側胃切除 19 例，P群：嘪門側胃切除 3 例）に対L, Retrospective に検討しその問題点に関し報告する. .【手術手技】 T 群：逆 J 型パウチ を作製し，導管と十二指腸，次に His 角，Pseudo fornix が形成されるよ うにパウチと食道を器械吻合する．D群：逆 J 型パウチを作製し，導管 と十二指腸, 残胃とパウチを器械吻合する.P群：逆 U 型パウチを作製 し, 食道と器械吻合し His 角, Pseudo fornix を形成する. 次にパウチと 残胃を器械吻合する. (方法】1) 手術時間を Roux-en-Y 法, Billroth-I 法と 比較した．2）術直後の食事摄取状況を調査した．3）愁訴をアンケート 調査した４）内視鏡にて食道，残胃，パウチを観察した。5）24時間持 続 $\mathrm{pH}$ モニターにて，アルカリ逆流（pH>7.0）を，"'Inを用いた経口消 化管動態シンチにて代用胃排出能（ $\left.\mathrm{T}_{1 / 2}\right)$ を測定した．6）全症例を腹部 食道温存 (E-Pre) - 非温存 (E-Abl), 間置空腸非屈曲 (IJ-Arc) - 屈曲 (IJ-Fle), 辺縁神経温存 (N-Pre) - 非温存 (N-Abl), 幽門輪保存 (P-Pre) ・非保存 (P-Abl) 群に分け, Retrospective に検討した. 7) 使用する器 械を保険点数上で検討した. [成績】 1) 本法は平均 $\mathrm{T}$ 群で 99.1 分, D 群は 61.9 分, 従来法より手術時間を要した. 2） $50 \%$ 食事拱取は術後平 均 15 日目であった３）愁訴は術後 1 年以降は減少した。4）アルカリ逆 流は T (E-Pre) 群で食道へ $6.7 \%, \mathrm{~T}(\mathrm{E}-\mathrm{Abl})$ 群は $49 \%, \mathrm{D}$ 群で食道へ $4.4 \%$ ，残胃へ $16.4 \%$ であった. 5) $\mathrm{T}_{1 / 2}$ は T (IJ-Arc) 群で 99.2 分, $\mathrm{T}$ (IJ-Fle) 群は 162.7 分，D群で 75.7 分であった. 6) T (E-Abl) 群で全例 に食道炎を, T (IJ-Fle, P-Pre) 群, P (P-Pre) 群で, Pouch 内に残查を 認めた。 7）胸やけ，逆流性食道炎は E-Abl 群に，もたれ感はIJ-Fle, PPre 群に出現し, N-Pre, Abl 群では愁訴に差はなかった．8）超過保険点 数は, 最低で $\mathrm{T} \cdot \mathrm{D}$ 群が 3200 点, $\mathrm{P}$ 群は 9400 点であった.【結論】パウ 于手術は間置腸管を屈曲させず，腹部食道を温存し，噴門側胃切除は幽 門形成術を付加することが肝要である. 
PS05-k

Optimizing Outcomes from Rectal Cancer Surgery

Church JM

(Department of Colorectal Surg, Cleveland Clinic)

The aim of surgery for rectal cancer is to cure the patient. This can only be done if all the malignant cells are removed or killed. Treatment fails therefore when viable cancer cells remain in the patient after surgery. This happens under two circumstances: 1 . A curable cancer is inadequately treated, or 2 . Cancer has spread outside the scope of even the best treatment. Surgeons cannot control the second situation but must ensure that the first does not happen. To so this they must ; 1) choose the right operation, 2) do it right. and 3) use adjuvant therapy where indicated. Choosing the right operation is crucial for rectal cancer as there are multiple treatment options. Preoperative staging by rectal examination, ultrasound, CT and MRI will allow sorting of the tumor by depth of invasion, nodal status, and distal spread, and will enable patients with advanced disease to be early disease may be offered local treatment. When surgery is performed a precise and radical anatomic dissection is essential to minimizing recurrence. The key here is to keep the mesorectum and its fascial envelope intact, for at least $5 \mathrm{~cm}$ below the lowest margin of the tumor. Reconstruction of gastrointestinal continuity may be with a colonic pouch or coloplasty to optimizing bowel function. Adjuvant treatment has been shown to minimizing local recurrence and to enhance survival, especially in patients with node positive disease. Optimal treatment of colorectal cancer means curing all curable cancers while preserving bowel function and quality of life. This is done by accurate preoperative staging, expert surgery and judicious use of adjuvant therapy.
PS05-02

討

河村 裕", 相原弘之", 富樫一智"), 神崎雅樹", 星野 徽"，岡田真 樹" ${ }^{2}$, 永井秀雄 ${ }^{2}$, 小西文雄"

（自治医科大学附属大宮医療センター外科", 自治医科大学消化器・D 般外科 $\left.{ }^{21}\right)$

【目的】直腸癌の遠位直腸間膜内へのリンパ節転移に関して検討し，リン パ節転移の点から見た適切な遠位側切除断端距離を明らかにする。対 象と方法】 1990 年から 2000 年までの間に直腸癌に対して切除を行った 症例のうち, 1 群りンバ節が大腸癌取扱い規約に則り腫瘍直下 (n1-T), 肛門側直腸間膜内 (n1-A), 口側直腸間膜内 (n1-O) として整理され, 組 織学的検索が行われた症例を対象とした. ただし組織学的深達度が $\mathrm{m}$ と診断された症例は除いた。対象症例 119 例の臨床病理学的因子を retrospective に検討した. 【結果】平均年齢は 64.3 歳で男性 77 例，女性 42 例であった．深達度は $\mathrm{sm}$ が 6 例, mpが 23 例, ss/a1 が $24 / 13$ 例, se /a 2 が $19 / 28$ 例, si/ai が $3 / 3$ 例であった. リンバ節転移はn $(-)$ が 71 例 $(59.7 \%), \mathrm{n} 1(+)$ が 45 例 $(37.8 \%), \mathrm{n} 2(+)$ が 11 例 $(9.2 \%), \mathrm{n}$ $3(+)$ が 2 例 $(2 \%)$ であった. リンパ節転移陽性の 46 例中, n1-A (+) が 12 例 $(26.1 \%), \mathrm{nl}-\mathrm{T}(+)$ が 33 例 $(71.7 \%)$, n1-O (+) が 27 例 (58.7\%)であった. n1-A と n1-T の転移の有無および n1-O と n1-T の転 移の有無に関してはそれぞれ相関が認められたが（ $\mathrm{p}=0.0003$ および $\mathrm{p}$ $=0.0005$, Fisher's exact test, 以下同), n1-A と n1-O の転移の有無には相 関が認められなかった $(\mathrm{p}=0.1466)$. 深達度別に $\mathrm{n} 1-\mathrm{A}$ の転移の有無を検 討すると smでは $0 / 5(0 \%), \mathrm{mp}$ では $1 / 23(4.3 \%), \mathrm{ss} / \mathrm{al}$ では $1 / 36$ (2.8\%)であったが, se/a2 では 9/46(19.6\%), si/ai では 1/5(20\%)で, 深達度を $\mathrm{ss} / \mathrm{a} 1$ までと $\mathrm{se} / \mathrm{a} 2$ 以上の 2 群に分けると転移頻度に有意差が 認められた $(\mathrm{p}=0.005)$ ．組織型別に検討すると, n1-A (+) であった 12 例は全例高分化型腺癌であった. n1-A (+) 症例のうち経過観察中に局 所再発が確認された症例は 4 例 $(33.3 \%)$ で, 全例初回手術時非治癒切除 であった.【まとめ1. 遠位の直腸間膜内へのリンパ節転移の頻度はn $(+)$ 症例中の $26.1 \%$ であった. 2. 深達度 ss/al までであれば遠位腸間膜 内への転移の頻度は低かった. 3.n1-A (+) であっても大腸癌取扱い規 約の 1 群リンパ節を郭清すれば局所は十分制御できると考えられた。

PS05-03 下部直腸癌（Rb）の適正側方リンパ節郭清 井原 厚，大谷剛正，中村隆俊，金澤秀紀，相原成昭，国場幸均，柿田 章

(北里大学外科)

【目的】下部直腸癌に対する側方リンパ節郭性の意義については未だ世界 的には認められていない．近年直腸癌症例の術式も根治性を重視すると ともに, 一方では肚門括約筋を温存した超低位前方切除術や自律神経温 存術式など Q. O.L. を考虑した維小手術が望まれる.術前診断に対する正 診率の向上に伴い, 術前診断でどこまで側方リンパ節を郭清すべきか, ま たどのような症例では側方りンパ節郭清を必要としないかを予測するこ とが重要である.【方法】過去 14 年間における大腸癌手術症例 1459 例中 側方リンパ節郭清を施行した下部直腸癌 $(\mathrm{Rb})$ 症例 159 例 (10.9\%) につ いて RETROSPECTIVE に臨床病理学的に検討し，直腸癌症例における 適正側方りンパ節郭清について検討した. 【対象】 $\mathrm{Rb}$ 症例のうち低位前方 切除術 (以下 LAR) 施行例 49 例および腹・会陰式切断術（以下 APR）施 行例 110 例の合計 159 例を対象とした.【結果]組織型は, wel : 92 例 (57.9 $\%), \bmod : 42$ 例 $(26.4 \%)$, por : 15 例 $(9.4 \%)$, muc: 7 例 $(4.4 \%)$, 未 分化癌： 1 例 $(0.6 \%)$, その他 2 例 $(1.2 \%)$. 壁深達度は, $\mathrm{m}: 2$ 例 $(1.3$ $\%), \mathrm{sm}: 7$ 例 $(4.4 \%), \mathrm{mp}: 37$ 例 $(23.3 \%), \mathrm{a} 1: 63$ 例 $(39.6 \%), \mathrm{a} 2$ : 46 例 $(28.9 \%)$, ai : 4 例 $(2.5 \%)$. リンパ節陽性例は 69 例 $(43.4 \%)$ で, 側方リンパ節陽性例は 19 例 (11.9\%)であった．単独側方リンパ節陽性例 も 2 例 $(1.4 \%)$ に認められ，いずれも低分化腺癌であった. 側方リンパ節 陽性例について検討すると, 組織型では, wel : 7/92 例 $(7.6 \%), \bmod$ : $6 / 42$ 例 (14.3\%), por：4/15 例 (28.3\%), muc: 1/7 例 (14.3\%), と分化 度の低いものほど側方リンパ節陽性率が高い傾向にあった．壁深達度で は, $\mathrm{mp} よ り$ 浅層では側方りンパ節陽性例は認められず, $\mathrm{mp}: 4 / 37$ 例 $(10.8 \%)$, a1 : 7/63 例 (11.1\%), a2 : 13/46 例 $(26.7 \%)$, ai : 1/4 例 $(25.0$ \%)であった. 5 年累積生存率では LAR : $76.6 \%, A P R ： 73.8 \%$ で有意差 は認められなかった.【まとめ】1.mp 以深の下部直腸癌の $11.9 \%$ に側方り ンパ節転移を認めた. $2 . \mathrm{mp}$ までの高分化腺癌では側方リンパ節転移は認 められず，自律神経温存術式を考慮すべきと考えた．3.低分化腺癌の 2 例に単独側方リンパ節転移（No270,282）を認め, 分化度の低い下部直腸 癌では側方リンパ節郭清を十分考慮した徹底郭清が必要である. 
PS05-04大腸癌に対する大動脈周囲リンパ節郭清の適応 山口茂樹", 山岸 茂", 市川靖史", 木村英明"2, 藤井正一"2), 池 秀

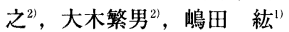

(横浜市立大学第 2 外科"，横浜市立大学市民総合医療センタ-22)

【目的】大腸癌の大動脈周囲リンパ節郭清の適応を検討する.【対象と方 法】1993 年からの術後 3 年以上経過した大腸癌根治切除 (n4 を含む) 496 例を対象とした．占居部位は右側結腸 $(\mathrm{A} \sim \mathrm{T}) 115$, 左側結腸 $(\mathrm{D}, \mathrm{S}) 175$, 值腸 206 だった. 216 郭清は右側では術前 $\mathrm{CT}$ 検查で 216 転移が疑われ た $7.8 \%(\mathrm{n}=9)$ ，左側では $\mathrm{N}(+) 52.8 \%(\mathrm{n}=94)$ ，直腸では $\mathrm{N}(+)$ ま たは SS/A1 以深 $76.2 \%(n=157)$ に行った. 216 の郭清範囲は IMA 上 $2 \mathrm{~cm}$ から大動脈分岐下まで, IVC 前面, 大動静脈間, 大動脈前面と左側 とした【結果】 496 例中 n (+) は右側結腸 $41.7 \%$, 左側結腸 $40.6 \%$, 直 腸 $42.7 \%$, 各群の累皘 5 年生存率は $66.6 \%, 71.8 \%, 71.1 \%$ で部位による 差は無かった. 216 郭清症例の 216 転移率は, 右側 $0 \%$, 左側 $5.3 \%$ (n $=5)$, 直腸 $2.5 \%(n=4)$ だった。これらのリンパ節転移状況は左側はす べてに $\mathrm{n} 2$ または $\mathrm{n} 3$ の転移を伴い, 直腸は 2 例に $253(+), 1$ 例に $\mathrm{n} 1$ (+) を伴い，1例は 216 単独転移だった． 216 リンパ節の平均転移数は $10.6 \pm 14.9$ 個, 最多 48 , 最少 1 だった. 216 陽性 9 例の累皘生存率は 1 年 $89.0 \%, 3$ 年 $51.9 \%, 5$ 年 $51.9 \%$ だった. 現在再発無く生存中の 3 例は すべて 216 転移が 2 個以下だった.一方 6 個以上の転移の 5 例は, 1 例は 1 年以内の死亡したものの, 4 例は 2 年以上の生存期間が得られ延命効 果が得られた. 再発形式は 216 リンパ節 2 例, 肺 3 例, 骨 1 , 局所 1 だっ た. 初発時 $216(-)$ の 216 再発例は 6 例 $(1.2 \%)$ だった。このうち右 側は非郭清の 1 例に再発をおこし 1 年後に血行性転移で失った. 左側, 直腸の 5 例中 3 例は郭清不足, 2 例は郭清範囲外再発 (16a2) だった。初 発, 再発を含む 216 転移率は右側 $\mathrm{n} 1, \mathrm{n} 2$ なし, $\mathrm{n} 3(+)$ の $14.3 \%$ だった. 同様に左側 $\mathrm{n} 1(+)$ の $4.4 \%, \mathrm{n} 2(+)$ の $5.6 \%, \mathrm{n} 3(+)$ の $71.4 \%$, 直 腸では上方 $\mathrm{n} 1(+)$ の $2.1 \%, \mathrm{n} 2(+): 0 \%, \mathrm{n} 3(+)$ の $57.1 \%$ に認め た. 216 郭清のための手術時間は 30 分から 1 時間程度延長するが, 重篤 な合併症は経験していない.【結語】右側結腸では 216 郭清の適応は明確 にできなかったが, 左側結腸と直腸の $\mathrm{n} 2$ 以上の症例は 216 郭清の適応 と思われた. また 216 少数転移例では根治の可能性があり積極的に切除 す心゙きと思われた。

PS05-05 S 状結腸癌と直腸癌における下腸間膜動脈根リンパ節 (253) 郭清の意義に関する検討

岡田真樹"，小島正幸"，冨樫一智"，佐藤知行"，尾野雅哉1", 堀江久 永", 遠藤則之", 古川泰司 ${ }^{11}$, 宮倉安幸", 鯉沼広治", 永井秀雄", 小西 文雄 ${ }^{21}$

(自治医科大学消化器一般外科", 自治医科大学大宮医療センター外 科年)

[目的］253リンパ節は S 状結腸癌と直腸癌に対して D3 郭清を行う場合 には郭清すべきリンパ節である.しかし 253 リンパ節転移陽性症例には 予後不良例が多いことから，253リンパ節は郭清する意義が小さいのでは ないかとする意見がある。 そこで 253 リンパ節郭清の意義について検討 した. [方法] 1.1980-1998 年の S 状結腸癌と直腸癌の手術例 956 例中, 根 治度 A で 253 転移陽性（n3）の症例について，その陽性率，組織型，深 達度, 再発の有無, 再発形式を調べた. $2.1990-1998$ 年の S 状結晹癌と直 腸癌の手術例 539 例中, 根治度 A で 253 転移陰性かつ 242 または 252 転 移陽性 $(\mathrm{n} 2)$ の症例について, 再発の有無, 再発形式を調べた. 3. 上記の $\mathrm{n} 3$ 症例と $\mathrm{n} 2$ 症例の生存率を比較した. [結果] 1 . 根治度 A で 253 転移陽 性 (n3) の症例は 9 例 $(0.94 \%)$ であった. 9 例の組織型は wel 6 例, mod 1 例, muc 2 例であった. 深達度は se が 7 例, ss が 1 例, ai が 1 例であっ た. 再発は 9 例中 7 例に認め, 7 例の無再発期間は 4-96 ケ月 (中央值 13 ヶ月）であった。初再発形式はn $4(+) 2$ 例, 肝 2 例, 肺 1 例, 局所 1 例, 腹膜播種 1 例であった. 2 . 根治度 A で 253 転移陰性かつ 242 または 252 転移陽性 (n2)の症例は 24 例であった。このうち再発を 13 例に認め, 13 例の無再発期間は 4-71 ケ月 (中央值 20 ケ月) であった. 初再発形式 は肝 4 例, 肺 5 例, 局所 3 例, 腹膜播種 1 例であり $4(+)$ はなかった。 3.5 年生存率は $\mathrm{n} 3$ 症例 $33 \%, \mathrm{n} 2$ 症例 $59 \%$ であった $(\mathrm{p}=0.029)$. [総括]根 治度 A で 253 転移陽性の症例は少数でありその多くは早期に再発を認め たこと, また根治度 A で 253 転移陰性かつ 242 または 252 転移陽性（n 2)の症例の再発例に扔ける初再発形式に $\mathrm{n} 4$ を認めないことより, S 状結 腸癌と直腸癌において 253 を郭清する意義は小さいのではないかと考え られた。 また 2 症例の予後は $\mathrm{n} 3$ 症例に比べて良好なことから, 242 また は 252 を郭清する意義は大きいと考えられた. すなわち 253 の郭清の意 義は 242 または 252 を十分に郭清するためにあると思われた。
PS06-01演題取り下げ

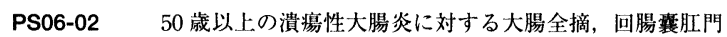
管吻合術の成績と問題点

小金井一隆，福島恒男

(横浜市立市民病院外科)

潰瘍性大腸炎に対する大腸全摘，回腸莗による再建術の適応は，かつて 50 歳以下とされたが, 近年, 術式の改良などにより, 50 歳以上でも施行 されるようになった. 今回は, 50 歳以上の大腸全摘, 回腸襄肛門管吻合 術（IACA）の成績と問題点を検討した.【対象】1993 年以後に横浜市立 市民病院で IACA を行った潰鹪性大腸炎症例 199 例で, これを手術時年 齢で 50 歳以上 (35 例) と, 50 歳未満 (164 例) にわけ, 合併症発生率と 排便回数, 漏便からみた排便機能について比較した. 50 歳以上の症例は 平均年令 56.9 歳, 男性 17 例, 女性 18 例で, 全大腸炎型が 34 例, 左側大 腸炎型が 1 例あった, 手術理由は, 難治 27 例, 重症 5 例, 癌合併 3 例で あった.【結果】各項目の結果を 50 歳以上, 未満の順に記載する. 1 , 術後 合併症：再手術を要した縫合不全は 0 例と 7 例 $(4.3 \%)$, 晚期縫合不全は 1 例 $(2.9 \%)$ と 3 例 $(1.8 \%)$ であった. 臨床症状と内視鏡所見により診 断した回腸慗炎は 3 例 $(8.6 \%)$ と 10 例 $(6.1 \%)$. 坐郕による治療を要し た残存直腸火は 3 例 $(8.6 \%)$ と 10 例 $(6.1 \%)$. staple line ulcer は 2 例 $(5.7 \%)$ と 9 例 $(5.5 \%)$ 。一度でも拡張を要した吻合部狭窄は 6 例 $(17$ $\%)$ と 30 例 $(18 \%)$ であった. 2, 排便機能：術後 1 年での最多一日排便 回数の平均は 7.9 回と 6.4 回, 漏便で術後 1 年以上 pad を使用した例は 5 例 $(14 \%)$ と 2 例 $(1.2 \%)$ であった. これら 2 項目を 50 歳台 (23 例) と 60 歳台（12 例）にわけてみると, 排便回数は 7.4 回と 8.8 回, 漏便で術 後 1 年以上 pad を用いた例は 0 例と 5 例 $(41 \%)$ であった. 5 例中 1 例 は術後 32 ヶ月目に漏便が消失したが, 4 例では残っている. [結語】潰瘍 性大腸炎に対する IACA は, 50 歳以上でも合併症の発生率が 50 歳末満 と差はなかった. 50 歳台では術後排便機能も良好に保たれ, 本術式の適 応となる. 60 藏台では排便回数が多く, $40 \%$ に漏便が残る点が問題と思 われた. 
PS06-03 難治性回腸表炎に対する抗生剂 2 郕併用療法の効果と QUALITY OF LIFE に及ほす影響

味村俊樹", 島田 正", 山崎一樹", 河原正樹", 上西紀夫"1, ジオンケッ

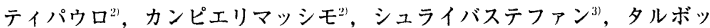
トイアン" , ニコルスジョン", カムマイケル"

(東京大学消化管外科・代謝栄養内分泌外科")，ボローニャ大学消化器内 科"2!，クリスチャンアルブレヒト大学第一内科 ${ }^{31}$ ，七ントマークス病院 ${ }^{41}$ )

背景：潰瘍性大腸炎に対する全大腸切除・回腸襄肘門 (管) 吻合術後の長 期合併症として回腸稚炎がしばしば問題となる. 経験的には抗生剂療法が 有効であるが, 難治性の回腸装炎に対する強力抗生剂療法の効果を評価し

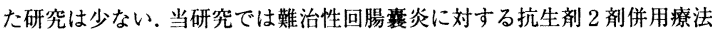
の効果と, 生活の質（Quality of Life：以下 QOL）に及ぼす影響を評価し た。

対象と方法：難治性活動性回腸震炎の患者を対象とした，その定義は（i） 過去 1 年間に最低 2 回以上の回腸震炎の既往がある再発性か, または抗生 版を継続して服用する必要のある持続性回腸襄炎であり，かつ (ii) 今回の 治療開始時点で Pouchitis Disease Activity Index（PDAI：炎症なし〜炎 症最悪 $=0$ 18) スコアが 7 以上の活動性回腸䧶炎である. 治療はメトロニ ダゾール $800 \mathrm{mg}$ または $1000 \mathrm{mg}$ 分 2 とシプロフロキサシン $\lg$ 分 2 を 4 週間投与し, 抗生剂治療前後の炎症の程度を臨床症状, 内視鏡像, 生検組 織像を総合的に得点化する PDAI スコアで評価した. 寞解は臨床的 PDAI スコア 2 以下, 内視鏡的スコア 1 以下, 全 PDAI スコア 4 以下と定義した. QOL は Inflammatory Bowel Disease Questionnaire（以下 IBDQ）で評価 した（最悪〜最善 $=32 \sim 224$ ).

結果：44 名（男性 24, 平均年齢 37.5 歳）が参加し，36 名（82\%）が寛解に 導入された．治療前後の PDAI スコア中央值は 12 (範囲：8-17）から 3 (1-10)に有意に改善し $(\mathrm{p}<0.0001), \mathrm{IBDQ}$ スコア中央值も $96.5(74-183)$ から $175(76$ - 215) に有意に改善した $(\mathrm{p}<0.0001)$. IBDQ スコアはPDAI スコアと有意に相関し $(\mathrm{r}=0.79 . \mathrm{p}<0.0001)$, 患者の全体的な満足度とも有 意に関連していた（ $\mathrm{p}<0.0001 ）$.

結論：本療法は，難治性回腸囊炎患者において炎症と QOL を著明に改善 し，極めて有効であった. IBDQ は回腸䔩炎の炎症の程度と良く相関し， 患者の QOL .を評価するのに有用であった.

PS06-04長期予後と再手術からみた Crohn 病手術術式の問題点

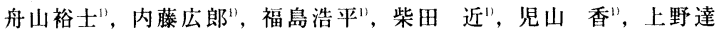
也", 橋本明彦"，北山卓"，西條文人"，松野正紀"

(東北大学胃腸外科", 東北大学肝胆膵外科" ${ }^{2 \prime}$ )

【目的】Crohn 病の術後合併症からみた術式の問題点について検討する ために, 再手術例における再発様式, 再発部位について解析した.【対象 ・方法】当教室にて腸病変に対してCrohn 病開腹手術をおこなった初回 手術例 183 例，第二回目手術例 87 例，第三回目手術例 32 例について, 手術術式, 再発部位, 再発様式について検討した. 初回手術例の内訳は, 男女比が $137 ： 46$, 手術時年令は 25.7 (12.8-63.7) 才，術後経過期間は 65.4 (0.1-369) カ月，小腸型 54 例，小腸大腸型 107 例，大腸型 22 例で あった。第二回目手術例の内訳は，男女比が $54: 23$, 手術時年令は 32.4 (14.4-59.4) 才, 術後経過期間は $47.2(0.2-255.3)$ 力月, 小腸型 20 例, 小腸大腸型 66 例, 大腸型 1 例であった. 第三回目手術例の内訳は, 男女 比が $26: 6$, 手術時年令は $34.0(22.6-66.1)$ 才, 術後経過期間は $41.3(0.8$ -193.1) 力月, 小腸型 6 例, 小腸大腸型 26 例であった。 累積再手術率は Kaplan-Meier 法, 有意差検定は Log-rank 法を用いた. 【結果】1. 術後累積 再手術率 : 初回, 第二回目, 第三回目手術ともに術後累積再手術率は同 様で手術を複数回を経ても予後は改善しなかった. 2. 切除小腸長 : 残存 小腸長は, 初回 $350(82-690)$ ，二回目 $240(80-532)$, 三回目 $208(80$ $-282) \mathrm{cm}$ と短縮して行くが, 切除小腸長は, 初回 $28(0-200)$, 二回目 $12(0-87)$, 三回目 $85(0-33) \mathrm{cm}$ と病変長とともに手術回を経る毎に 短縮していた．狭窄形成術併用例では切除長の節約効果が得られた. 3.

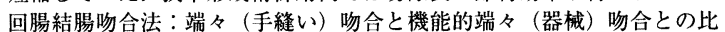
較では差がなく器械吻合で再手術率は改善しなかった. 4. 再発部位：狭 窄形成部位と吻合部とではその半数が同頻度で再手術の適応部位と なっており再手術のリスクは同じと考えられたが, 狭窄形成術では明ら かに瘦孔形成が少なかった。 また, 同じ頻度で新たな病変が出現し再手 術の適応部位となっていた.【まとめ】狭害形成術は小腸長の温存に有効 であったが，手術部位による再手術のリスクは吻合部と同等であった。 器械吻合は再手術率を改善しなかった。
PS06-05 クローン病瘦孔症例に対する術式と予後 池内浩基, 荘司康嗣, 野田雅史, 柳 秀憲, 山村武平 (兵庫医科大学病院第 2 外科)

[目的]クローン病の瘦孔に対しては, 特に対側腸管の処理方法が論点と なっている. 今回我々は, 当科で経験したクローン病瘦孔症例の, 手術 適応，手術術式，予後等につき検討を行った。[方法] 対象は当科で経験 したクローン病手術症例 213 例のうち, 瘦孔が存在した 60 例, $28.2 \%$ で, 延べ手術回数は 63 回, 摟孔の数は合計 86 である. [結果] 1. 瘦孔の 場所：内瘦が $80.2 \%$ ，外瘻が $19.8 \%$ で，内瘦では，回腸から結腸への瘦 孔が 20 瘦孔 $(29 \%)$ と最も多く見られた。 また，責任腸管別では回腸が 60 瘦孔 $(69.8 \%)$, 結腸が 18 瘦孔 $(20.9 \%)$, 前回吻合部が 7 瘦孔 $(8.1$ $\%)$, 直腸が 1 瘦孔 $(1.2 \%)$ であった. 2 . 瘦孔合併症例の主な手術適応： 内瘦症例の場合, 多くの症例で狭窄や炎症性腫瘤, 膿瘍を合併しており, 狭窄が 23 例, $36.5 \%$ と最も多く，内瘦形成のみが主な手術適応となった のは $14.3 \%$ と少数であった．また，これは回腸－S 状結腸瘦または回腸 一直腸瘦のために，頻回な下痢，または肚門病変の悪化を主訴とする症 例であった. 3. 瘦孔症例の手術術式：回腸または回腸と右側結腸間に存 在する瘦孔はほほ全例, en bloc に摘出していた. その他の部位の瘦孔に 関しては, 主病変の切除 +対側腸の縫合閉鎖を基本術式としていたが, 主病変と対側腸管との間に炎症性腫瘤や滞瘍が存在し，対側腸管の奨膜 面にまで広範囲に炎症が存在する症例では切除をおこなっていた，瘦孔 周囲の炎症が, 軽度なものでは, stapler 用いた fisturectomy も可能で あった、いずれの症例も対側腸管の処理部に縫合不全を生じた症例はな かった. 外瘦症例には全例, 主病変の切除+瘦孔择爬を行っていた． 4. 術後合併症：释合不全を 1 例に認めたが, これは主病変の切除部の縫合 不全であった. 5 . 術後経過：13 例, $20.6 \%$ に再手術が行われていた. 再 手術の原因は対側腸管切除部に再発を認めた 1 例以外は, すべて他病変 の再発であった. [まとめ] 1. クローン病手術症例のうち $28.2 \%$ に瘦孔を 認めた. 2. 内瘦症例の一般的な術式は, 主病変の切除 +対側腸管の綘合 閉鎖であったが，対側腸管の状態により切除を行ったり, stapled fistulectomy が可能な症例も存在した.

PS07-01演題取り下げ 
PS07-02 C 型肝細胞癌の肝炎状態における肝組織中 $\mathrm{p} 21 \mathrm{WAF} 1 /$ CIP1mRNA 発現と残肝再発

小林 進, 浅野武秀, 剣持 敬, 西郷健一, 岩崎好太郎, 松井芳文, 丸 山通弘, 浦島哲郎, 三浦文彦, 落合武德

(千葉大学第二外科)

【目的】 $\mathrm{p} 21 \mathrm{WAF} 1 /$ 【目的】 $21 \mathrm{WAF} 1 / \mathrm{CIP1}$ (p21) は主に wild-type p $53 に よ り$ 発現誘導され, 正常細胞においては G1 休止期を誘導すること により, 細胞周期を制御している.しかし, 癌細胞においては 21 は充 分に発現せず， 細胞は無秩序に増殖をおこしていると考えられている. 肝細胞癌は発癌因子 (ウイルス発癌) が比較的明らかであり, また肝細 胞癌患者肝切除後も残肝内に発癌因子としての肝炎ウイルスを保持し 続けるという大きな特徴をもっている. 今回, 特にC 型肝炎ウイルス感 染と肝細胞癌の $\mathrm{p} 21 \mathrm{mRNA}$ 発現からみた肝細胞癌の治療戦略につき検 討した. (対象と方法】 A) p21mRNA 発現; 肝細胞癌 16 例の p21mRNA 発現を Northern Blot Hybridization 法により検討した. B) 術後生存率 ; 観察期間を 1991 年 6 月より 1998 年 12 月までとし, HCV (+)；48 例に おいて, 肝切除後 2 年間, あるいは再発までの期間の半期以上, GPT 值が 80 以上持続したものを GPT 高值群とし, その高值例, 低值例で比 較検討した.【結果】A) p21mRNA 発現; HCV $(+)$ 群の GPT 高值例に おいて, 非癌部肝組織における $21 \mathrm{mRNA} の$ 著明な発現增大が見られる が, 癌部では逆に著明な低下が見られた. HBV $(+)$ 群では, 癌部, 非 癌部ともに p21mRNAの発現は低レベルであった. B) 術後生存率; $\mathrm{HCV}(+)$ 群において, 術後肝炎状態となる症例が多く, GPT 高值例は 低值例に比較し, 無再発生存率は有意に低く, 予後は不良であった。 無 再発生存期間に影響する因子の多変量解析では HCV 群では GPT の高 低が強い因子であった.【考察】 HCV (+) 症例では, 肝切除後の肝炎状 態が続く症例ほど早期に再発が見られるが, 肝炎状態における肝細胞の 破壊再生からくる細胞増殖刺激（高癌化状態）に対し, p21mRNAの発 現增大は発㿋を必死に抑制していると考えられる。 その肝細胞の破壊再 生の過程で p53 遺伝子等に異常が生じると p $21 \mathrm{mRNA}$ 発現の維持が不 可能となり, 再度発癌につながると考えられる. C 型肝細胞癌に対して は根治的手術以外に肝切除後の肝炎状態に対する対策も行い, 癌に再び ならない治療も考虑にいれるべきと考える。

PS07-03肝細胞癌術後再発に対する動注化学療法における DPD 免疫染色の検討一癌の heterogeneity-

川畑方博, 福田秀一, 奥田康司, 古川 哲, 児玉孝仁, 濱田 茂, 江里 口直文, 青柳成明

(久留米大学外科学)

【目的】 DPD (dihydropyrimidine dehydrogenase) は 5-FU の律速分解酵 素であり，5-FU 感受性との相関性が報告されている. しかしながら, 肝 細胞癌 (HCC)においては 5-FUに対する種々の感受性をもつ細胞クロー ンよりなる癌病巣も多いと考えられる. 今回, 主腫瘍の DPD 免疫染色性 と術後 FP (5-FU + CDDP) 動注効果の相関性について検討した. 【対象と 方法】肝切除後, 肝内再発結節に対してFP動注を施行した 19 例を対象 とした。切除腫瘍の DPD 免疫染色はDPD モノクローナル抗体を用い SAB 法にて行った。 DPD の発現は, 腫瘍全体が強く発現した homointense (homo-I), 不均一に発現した hetero, 腫瘍全体に発現を認めな かった homo-weak (homo-W) に分類し, 動注効果との相関性を検討し た.【結果】DPD 発現の内訳は homo-I 4 例, hetero 9 例, homo-W 6 例で あった。再発結節に対する動注効果を検討すると, homo-I 4 例中 PD 3 例, PR1 例, hetero 9 例中 PD 2 例, NC 2 例, PR3 例, CR 2 例, homo$\mathrm{W} 6$ 例 中 PD 1 例, NC 1 例, PR1 例, CR3 例 で, homo-I と PD, homo$\mathrm{W}$ と CR で有意な相関を認め $(\mathrm{p}=0.0472)$, homo-I, hetero, homo-W の順 に奏功率の増加を認めた. DPD 発現が heterogeneity を示した 9 例の再 発結節に対する動注効果は一定ではなかった. DPD 発現と腫瘍径, 肉眼 型, 各病理学的因子, 背景肝病変との間に相関性は認めなかった.【まと めIDPD 発現が heterogeneity を示す HCCにおいては, 再発病巣は種々 の 5-FU 感受性を持った細胞クローンから成り立つ事が想定され動注効 果は様々であった.一方, DPD 発現が homogeneity を示す HCCにおい てはDPD 免疫染色は再発結節に対する動注効果予測に有用であり, 他 の薬剤感受性因子の発現を明らかにする事で, 有効薬剤の選択指針とな りうる事が示唆された。
PS07-04進行肝細胞癌（HCC）の病態からみた経皮的肝灌流 (PIHP) の有効性の検討

岩崎 武, 具 英成, 富永正寞, 福本 巧, 高橋徹也, 千堂宏義, 木戸 正浩, 高橋応典, 黑田嘉和

(神戸大学第 1 外科)

【目的】私たちは従来長期予後の期待できなかった切除不能・多発進行 HCCに対し PIHPを軸とした集学的治療により 5 年を越える長期生存 例を得ている. 今回は予後因子の解析により病態からみたPIHPの有効 性を検討した. 【対象・方法】対象は 1989 年 6 月〜2000 年 3 月に PIHP を施行した肝切除後再発を含む切除不能 43 例と隇量肝切除を併用した 15 例の計 58 例で, 年齢は $12 \sim 73$ 歳 (平均 54.8 歳), $\mathrm{HBsAg}, \mathrm{HCV}$ 陽性 が各々 25,28 例で 33 例に LC を認めた. 全例 5 個以上の IM を有する StageIV 高度進行例で主腫瘍最大径は $7.1 \pm 5.0 \mathrm{~cm}$, StageIVB 11 例, Vp 312 例, Vv2 8 例に認めた. PIHP は 1 症例 $1 \sim 4$ 回, 延べ 92 回施行し た．抗癌剤はアドリアシン $\left(60-150 \mathrm{mg} / \mathrm{m}^{2}\right)$ またはシスプラチン $(120$ $200 \mathrm{mg} / \mathrm{m}^{2}$ ) を用い 14 例に両者を併用した. 予後因子は宿主側では年齢, 性別, ウイルスマーカー, LC の有無, 血清 Alb, T-Bil, AST, 血小板数, ICGR15など, 腫崵因子では腫瘍径, 肉眼型, Stage, 脈管侵襲 (Vp3, Vv2), 減量肝切除の有無等を変量とし, 生存については比例ハザードモ デル, 腫瘍直接効果についてはロジスティック回帰分析により検討し た.【結果】腫場直接効果は CR 10, PR 27, NC 13, PD 7, 判定不能 1 例で奏 効率は $63.8 \%$ であった．全体の生存率は $1,3,5$ 年で $72.0,43.5,24.6 \%$, Stage IVA では $82.7,50.8,28.6 \%$ であったが Stage IVB では 1 年 $27.3 \%$, 3 年 $0 \%$ と不良であった. 生存予後に関する単変量解析でウイルスマー

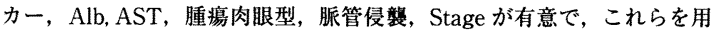
いた多変量解析では Alb $(\mathrm{p}=.001)$ と AST $(\mathrm{p}=.008)$ が有意な予後

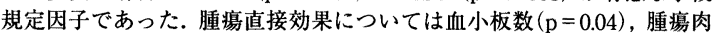
眼型 $(\mathrm{p}=0.04)$ が有意で, 血小板が低值でびまん型の症例で奏効率が低 かった.【まとめ】PIHP の効果には HCC の脈管侵㱩などの腫瘍因子より 蛋白合成能, 肝炎活動度といった肝障害度すなわち背景肝の病態の関与 が大きいことが判明した．脈管侵警例や巨大腫場といえども肝機能良好 で肝炎の活動度の低い例に対してはPIHP を軸としたより積極的な治療 戦略により長期予後の向上が得られる可能性が示晙された。

PS07-05 小型肝細胞癌に対する肝血流遮断下経皮的熱凝固療法 柴田高, 森田哲史, 池田公正, 鈴木 玲, 塚原康生, 北田昌之, 島野 高志

（市立豊中病院外科）

【目的】小型肝細胞癌に対し我々はIVRの手法を用いた肝血流遮断法を 開発し, 経皮的熱凝固することでその凝固域の拡大と局所制御能をあげ ることに成功した．今回，マイクロ波およびラジオ波による凝固域との 比較を動物実験し, 肝細胞癌症例に対し肝動静脈血流遮断下経皮的熱凝 固療法を施行した.【方法】生体豚 5 頭を全身麻酔開腹下に求いて凝固実 験を施行し，また肝門の肝動脈門脈血流遮断での凝固比較した. マイク 口波新型電極と RFAcool-tip 電極の凝固比較も同時に施行した. 臨床例 は肝細胞癌 43 例で通常の経皮的マイクロ波凝固 (PMCT) 7 例（新型マ イクロ波電極 2 例), 担癌区域の肝静脈バルーン遮断で門脈血流を遮断 し同時に肝動脈遮断で経皮的マイクロ波凝固 (IPMCT) 31 例に施行, 肝血流遮断下経皮的 RF 波凝固 (IRFA) は 5 例に施行した。血流遮断お よび凝固直後の効果判定は門脈相造影下 CTにて造影欠損状態を確認 し, 凝固域の判定は術後 1 週間目の造影 CT で行った. 【結果】動物実験 ではマイクロ波新型電極が RFAcool-tip 電極より広範囲で強い凝固域を 示した. また両者とも血流遮断することで有意に凝固域の拡大を示し た. 肝細胞癌の PMCT5 例の腫瘍径は平均 $16.2 \mathrm{~mm}$ で $60 \mathrm{~W}$ 平均凝固時 間は 8 分で平均凝固径 $28 \mathrm{~mm}$ に対し新型電極では $60 \mathrm{~W} 5$ 分で $30 \mathrm{~mm}$ で あった. IPMCT31 例の腫韵径は平均 $22 \mathrm{~mm}$ で $40 \sim 60 \mathrm{~W}$ 平均凝固時間 5.6 分で平均疑固径 $42.4 \mathrm{~mm}$ (P<0.01) であった. 6 ヶ月以内の局所再発 率は PMCT 20\% (1/5) IPMCT3\% (1/31) であった. 合併症は IPMCT 例に肝膿瘍, 胆汁瘦を 1 例認めた. IRFA は 5 例は平均腫瘍径 $36.2 \mathrm{~mm}$ で 40〜 50W, 3〜20 分の凝固で平均凝固径は $49.6 \mathrm{~mm}$ であった. しかし 1 週間後の CT で大型腫瘍不完全凝固を 1 例認めた. 【結語】 小型肝細胞癌 の経皮的熱凝固においては肝血流を制御することで局所治療効果の向 上が望めた。 
PS08-01 肝細胞癌切除後症例に対する予防的 chemolipiodolization

霜田光義, 坂東 正, 岸本浩史, 長田拓哉, 津田祐子, 山崎一麿, 貫井 裕次, 笹原孝太郎, 濱名俊泰, 塚田一博

(富山医科薬科大学第 2 外科)

【目的】肝細胞癌切除後の残肝再発は高率であり, 長期生存を得るために は術後の再発をできる限り早期に発見して治療することと, 多中心性発 癌を含めた再発に対する対策が必要である，当科では US, CTに加えて 血管造影を年 1 2 回程度行っており, 術後再発の早期発見に努めると ともに，再発抑制を目的として prophylacticに chemolipiodolization (PCL)を行うことを原則としている. 今回, 肝細胞癌切除後症例に対す る PCL の成績を検討した. 【対象と方法】1980 年から 1999 年 2 月までに 肝細胞癌症例 72 例に 81 回の肝切除を施行した.このうち絶対非治瘾切 除 10 例, 術後 3 力月以内再発 4 例, 在院死亡 5 例, 消息不明 2 例, 2 回目肝切除後のみ PCL 施行 2 例を除く 49 例を対象とした. 対象を PCL を行った A 群 26 例と行わなかった B 群 23 例にわけ, その背景因子と 再発様式, 生存率について検討し, さらに各群の予後決定因子について 検討した.【結果】両群の背景因子には差を認めなかった。無再発累積 3 年生存率は $\mathrm{A}$ 群 $51 \%$, B 群 $19 \%$ で A 群が有意に良好であった．また累 積 3 年および 5 年生存率もそれぞれ A 群; $96 \%, 79 \%, \mathrm{~B}$ 群 ; $46 \%, 27$ $\%$ と A 群が有意に良好であった. 再発は A 群 16 例, $62 \%$, B 群 19 例, $83 \%$ に認められた. 術後 2 年未満の早期残肝再発は $\mathrm{A}$ 群 7 例（単発 3 例, 多発 4 例), B 群 16 例 (単発 3 例, 多発 13 例) で B 群が有意に多く, 残肝多発再発も $\mathrm{B}$ 群で有意に高率であった。早期残肝再発例の 5 生率は $\mathrm{A}$ 群 $60 \%$, B 群 $6 \%$ と著しい差が認められた. 一方, 術後 2 年以降の晚 期残肝再発は $\mathrm{A}$ 群 10 例 (単発 6 例, 多発 3 例, 肝外 1 例), B 群 3 例 (単発 1 例, 多発 2 例) で $\mathrm{A}$ 群に多かったが, 生存率には差を認めなかっ た. B 群の予後決定因子は stage, 腫瘍個数, 根治度であったが, A 群で は有意な予後決定因子は認めなかった.【総括】PLCにより早期残肝再発 が隇少し予後が向上したと考えられた。

\section{PS08-02進行肝細胞癌における肝切除術後予防的動注化学療法の} 治療成績

桂巻 正, 木村康利, 本間敏男, 永山 稳, 目黒 諴, 古烟智久, 浦 英樹, 秦 史壮, 向谷充宏, 平田公一

(札沅医科大学第 1 外科)

【目的】肝細胞癌において StageIII, IVa や StageII で腫瘍径が大きい症 例は再発率が高い.このような肝細胞癌を進行肝癌と規定し, 肝切除後 に術後動注化学療法を施行して生存率の改善を報告してきた. 今までの 報告は使用薬剂が不統一であったので, 今回 epirubicin を投与した症例 のみを対象として，その効果について検討した。対象】過去 5 年間で経 験した StageIII, IVa, StageII で腫瘍径 $8 \mathrm{~cm}$ 以上の肝細胞癌 44 例を対象 とした. 動注群は 14 例（StageIVa : 8 例, StageIII : 4 例, StageII $: 2$ 例), 非動注群は 30 例 (StageIVa $: 10$ 例, StageIII $: 10$ 例, StageII $: 10$ 例) であた。非動注群は術後補助療法は施行されていない。組織学的に vp1, vv1 以上の脈管浸潤を認めた症例は動注群で 8 例 (64.3\%), 非動注 群で 11 例 $(36.7 \%)$ であった. 動注化学療法は大腿動脈経由でリザーバー を留置し, epirubicin $10 \mathrm{mg} /$ week 【結果】観察期間は動注群で 3-42 ケ月・中央值 22 ヶ月, 非動注群では 1-50 ケ月・中央值 22.5 ケ年あった. 1 年, 3 年生存率は非動注群は $81.0 \%, 38.5 \%$, 動注群で $92.3 \%, 92.3 \%$ で動注群は有意に良好であった $(\mathrm{P}<0.05)$. 動注群で死亡した症例は 1 例のみで, 動注に起因した敗血症 による他病死であった，組織学的に脈管浸潤を認めた症例（vpl,vv1 以上）は非動注群 11 例で 1 年, 3 年生存率は $55.6 \%, 12.3 \%$ と極めて不 良であったが, 動注群では 8 例で 1 年生存率は $100 \%$, 観察期間 3-43 ヶ月 (平均観察期間 22.9 ケ)において死亡例は経験していない. [考察] 進行肝細胞癌では手術で画像診断で捕らえられている腫瘍を完全切除 してもミクロレベルの腫場細胞が遺残していると仮定して治療する必 要があると考えられる. そういう意味では術後予防的動注療法は施行基 準を明確に設けることで, 進行肝癌に対して有用な治療戦略になると考 えられた。
PS08-03 C 型肝炎由来肝硬変患者の肝細胞癌切除後の初発再発と 血清 ALT 值との関係

蓮尾公篤", 利野 靖", 今田敏夫", 多羅尾和郎 ${ }^{21}$, 武宮省冶 ${ }^{21}$, 高梨吉 則"

(横浜市立大学第 1 外科"，神奈川県立がんセンター消化器科 $\left.{ }^{21}\right)$

[目的] 肝細胞癌の肝再発促進に血清高 ALT 值が関係しているか否か を, C 型肝炎由来肝硬変で肝細胞癌患者の切除症例にて検討した. [対 象, 方法] 対象は, C 型肝炎由来の肝硬変で門脈にも肝静脈にも浸潤が 無い単発の肝細胞癌切除症例 33 例で, 術後 3 年以上経過観察されてい るものを対象とした，それらを肝㖪における炎症性肝細胞壊死のマー カーとして良く知られている血清 ALT 值のレベルによって次の 2 群に 分けた. 1 つは, 肝切除後最初の再発までの間に血清 ALT 值の最高值が 1 度でも 80/INUを超えるか, 或いは常に80/INU 以上のレベルにいる 患者 17 例の群で, これを高ALT 群とし，もう 1 つは血清 ALT の最高 値が 1 度も $80 / \mathrm{INU}$ を超えない患者 16 例の群で, これを低 ALT 群と し, 肝切除後最初の肝再発までの間観察した. [結果]高 ALT 群は 3 年間 で 70.6\%の肝再発を来たしたのに対して, 低 ALT 群の再発は同期間で 僅かに $18.8 \%$ のみであった $(\mathrm{p}<0.05)$. 累積無肝再発率においても, 2 群間には大きな有意差を生じた $(\mathrm{p}=0.0201)$. 肝再発患者における肝切除 から最初の肝再発までの平均再発期間は, 高 ALT 群においては $23.6 \pm$ 2.8 ケ无あるのに対して，低 ALT 群では $49.3 \pm 9.7$ ケと明らかに高 ALT 群の方が短いものであった $(\mathrm{p}<0.02)$. [結論]これらの結果は次の 可能性を示した. C 型肝炎由来肝硬変患者の肝細胞㾔切除症例におい て, 高 ALT 群で肝細胞癌の再発発育が促進されたと言う事は, 言い換え れば肝切除後に抗炎症剂等で血清 ALT 值の上昇を押さえる事が出来れ ば, 肝再発までの平均約 2 年という期間を延長させる事が出来る可能性 がある.

PS08-04 C 型肝炎関連肝細胞癌の遠隔成績向上における肝切除後 インターフェロン療法の意義

久保正二"1, 広橋一裕", 田中 宏", 首藤太一"1, 竹村茂一", 山本隆 嗣", 山崎 修"), 井川澄人 ${ }^{32}$, 木下博明”

(大阪市立大学第二外科 ${ }^{11}$, 大阪市立総合医療センター ${ }^{2)}$, 城東中央病 院年)

[目的]肝細胞癌（以下, 肝癌）は主として肝炎ウィルスによる高癌化病 態にある慢性肝疾患から発生するため, 肝癌のみならず肝炎ウィルスに 対する治療が必要と考えられる. そこで C 型肝炎関連肝癌切除後インタ 一フエロン (IFN) 療法の Randomized study の成績を検討した. [対象と 方法］対象は C 型肝炎関連肝癌切除後 IFN 投与の Prospective randomized trial を行った 30 例で，これら症例を IFN 投与群（15例）と非投与 群（15 例）にふり分け, IFN 投与群ではIFN-alpha を 2 年間投与した. な打両群の背景因子に差はみられなかった。 [結果] IFN 療法の効果は CR 2 例, PR 6 例, NR 7 例であった. IFN 投与群の術後無再発生存率 $(\mathrm{P}=0.065)$, 累積生存率 $(\mathrm{P}=0.013)$ ともに IFN 非投与群に比較し良好 であった. [まとめ]C 型関連肝癌に対する肝切除後の IFN 療法は術後再 発を抑制し，その遠隔成績を向上させると考えられた。 
PS08-05肝細胞癌における DAP-kinase 発現の意義 松本 寛，長尾美津男，金廣裕道，久永倫聖，青松幸雄，高 済峯，藤 井久男, 石川博文, 小山文一, 小川護仁, 中島祥介

(奈良県立医科大学第 1 外科教室)

【目的】アポトーシスは, 慢性肝障害や劇症肝炎など多くの肝疾患に関与 しており，また種々の癌においてアポトーシス機構の破綻がその発生・ 進展に関与している. Death-associated protein (DAP) - kinase はアポ トーシスの positivè mediator であり，DAP-kinase の発現の消失は種々 の癌や B-cell lymphoma で報告されている. 肝細胞癌の切除後には残肝 再発が多く，簡便な方法での悪性度の評価が重要である，今回我々は肝 細胞癌における DAP-kinase の発現と臨床病理学的因子や予後との関連 を調べ, 癌悪性度診断での意義を検討した.【方法】1995 年 1 月から 1999 年 9 月の肝細胞癌切除例 43 例を対象とした. DAP-kinase の発現を凍結 切片での免疫組織染色および Western Blot Analysisにて検討し，予後 との関連を検討した. TUNEL 法でのアポトーシス細胞数を apoptotic index (AI) として算出した.【結果】肝細胞癌での DAP-kinase 陽性例は 16 例 $(37.2 \%)$ であった. Western blotting を 9 例に行い, 免疫組織染色 の結果と 8 例 $(88.9 \%)$ の一致を認めた. 臨床病理学的因子の検討では $\alpha$-fetoprotein, 組織学的門脈侵襲 (vp), 組織学的分化度が DAP-kinase 発現の有無と関連を認めた．TUNEL 法によりアポトーシスを検討した ところ，DAP-kinase 陽性例でアポトーシスが多く見られた $(\mathrm{p}<0.01)$. 再発率を検討したところ, DAP-kinase 陽性例は陰性例に比べ有意に再 発率は低かった $(\mathrm{p}<0.01)$. 生存率でも陽性例は陰性例に比べ有意に良好 であった $(\mathrm{p}<0.05)$. 多変量解析では, DAP-kinase は独立した再発予測 因子であった.【まとめ】肝細胞癌におけるアポトーシス機構の破綻は, 肝癌の進展に深く関与している. したがって肝細胞癌での DAP-kinase の発現の検討は，転移再発の予測に有用であると思われる。

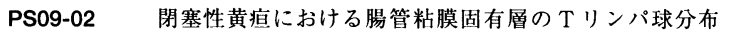
の変化

佐野智英, 味木徹夫, 羽原一登, 竹山宜典, 具 英成, 黒田嘉和 (神戸大学第 1 外科)

【目的】閉塞性黄疸時には bacterial translocation が起こりやすく, その 原因として腸管粘膜バリアーの破綻が重要であるとされている. われわ れは腸管粘膜バリアーの主体をなす粘膜固有層の CD4, CD8 陽性 T リ ンパ球の分布と CD4, CD8 陽性 T リンパ球が全身循環から粘膜固有層 にホーミングする際に重要とされる接着分子 MAdCAM-1の発現につ いて検討したので報告する.【方法】 Wistar 系雄性ラット $(220 \sim 250 \mathrm{~g})$ を 用いて単開腹群 $(n=9)$, 閉塞性黄疸群 $(n=9)$ をそれぞれ作成し, 術後 7 日目に犠牲死させ空腸, 回腸を摘出. 凍結切片を作成し抗 CD4, 抗 CD 8, 抗 MAdCAM-1 抗体を用いて免疫組織学的に粘膜固有層の CD4, CD8 Tリンパ球数と同部位の毛細血管細胞内皮における MAdCAM-1 の発 現を検討した. 染色後 1 切片につき 100 倍視野にて無作為に 5 視野を選 び，Photograb（Macintosh）にて陽性細胞数を計測した. [結果】 CD4 陽性 T リンパ球数の平均值は空腸, 回腸とも単開腹群に比べ閉塞性黄疸 群で隇少する傾向がみられた. (空腸 単開腹群 : 閉塞性黄疸群 $=50.67$ 個 : 38.76 個, 回腸 単開腹群 : 閉塞性黄疸群 $=56.68$ 個 $\mathrm{v}: 35.83$ 個 $) \mathrm{CD}$ 8 陽性 Tリンパ数の平均值は空腸, 回腸とも単開腹群に比べ閉塞性黄疸 群で隇少する傾向がみられた. (空腸 単開腹群：閉塞性黄疸群 $=27.67$ 個 $=17.65$ 個, 回腸 単開腹群: 閉塞性黄疸群 $=24.89$ 個 : 13.83 個 $)$ 毛細 血管細胞内皮の MAdCAM-1の発現は空腸, 回腸とも単開腹群に比べ閉 塞性黄疸群で減少した. (空腸 単開腹群 : 閉塞性黄疸群 $=1.86$ 個 : 1.02 個, 回腸 単開腹群 : 閉塞性黄㾝群 $=2.43$ 個 $: 1.23$ 個, $\mathrm{p}<0.01$ )【まとめ】 閉塞性黄㾝時における粘膜固有層での CD4, CD8 陽性 Tリンパ球数の 減少が腸管粘膜バリアーの破綻の一因である可能性が示唆され, その機 序としてMAdCAM-1 の発現低下が考えられた。

PS09-03閉塞性黄㾝時の抗炎症反応と隇黄不良

木村文夫", 宮崎 勝"2, 伊藤 博"', 諏訪敏一"1, 杉浦敏之"), 篠田德 三1

(大宮赤十字病院外科"1，千葉大学第 1 外科 ${ }^{21}$ )

【目的】閉塞性黄㾝時の抗炎症反応と肝機能, 胆道感染及び隇黄不良との 関連を検討した.【方法】対象はPTCD を施行した閉塞性黄㾝症例 35 例 で, PTCD 前及び 14 日後に末梢血を採取し Interleukin (IL) -6, IL-10, IL-1 receptor antagonist (IL-1ra), Soluble tumor necrosis factor receptor p55（STNFR）及び Soluble CD14（sCD14）を ELISAにて測定し, 血液生化学, 凝固系, 血中 Bilirubin 半隇期, 胆汁培養との関係について 検討した.【成績】(1) 黄㾝例の血中 IL-6, IL-10, IL-1ra 及び STNFR は対 照に比較して有意に高值を示し，減黄により低下した（各々 $\mathrm{p}<0.01 ）$. 黄疸例では血中 sCD14 も上昇していたが, 減黄後も低下しなかった. (2) IL-10 は Prothrombin time $(\mathrm{r}=+0.60)$ と正の, IL-6 は Hepaplastin test $(\mathrm{r}=-0.67)$ と負の相関を認めた. sCD14 は Alkaline phosphatase（r $=-0.52)$ と負の相関を示した. (3) 血中 IL-6 及び STNFR は胆汁培養陽 性例が陰性例に比較して有意に高值を示した $(\mathrm{P}<0.001) . \mathrm{sCD} 14$ の上昇 は胆汁培養と関連を認めなかった. (4) Bilirubin 半滅期は胆汁流量 ( $\mathrm{r}$ $=-0.40)$ と負の相関を, IL-10 $(r=+0.67)$ と正の相関を示した. Bilirubin 半減期と肝機能及び凝固系は関連を認めなかった. (5) Bilirubin 半滅 期が 21 日以上であった減黄不良例 $(n=4)$ は, 全例が胆汁培養陰性で あった，隇黄不良例では胆汁流量が，1 例 (1880ml) を除き，少なく(207 $\pm 114 \mathrm{ml}$ vs. $407 \pm 73)$, IL-10 (14.1 \pm 5.3 vs. $5.2 \pm 3.7)$ 及び STNFR (7933 \pm 5918 vs. $2284 \pm 2734)$ が有意に高值を示した $(\mathrm{p}<0.05)$. 凝固系には差 を認めなかった.【結語】(1) 閉塞性黄疸時には抗炎症反応が起きており, その反応は肝予備能低下, 胆道感染, 滅黄不良と関連を示した. (2) IL6 及び STNFR は胆道感染の鋭敏な指標になると考えられた. (3) SCD14 の上昇は腸管由来の endotoxin への暴露を示唆しており，胆管上皮の荒 廃に関連している可能性が示唆された. (4) 抗炎症反応は隇黄不良にい たる肝細胞障害に強く関連していると考えられた。 
PS09-04 胆道癌肝切除術前の自己胆汁腸管内再注入の有用性の検 討

杉田光隆, 遠藤 格, 藤井義郎, 田中邦哉, 渡会伸治, 関戸 仁, 嶋田 紘

(横浜市立大学第 2 外科)

【目的】胆道癌肝切除術前症例における, 減黄のための自己胆汁腸管内再 注入の有用性について検討した.【対象および方法】平成 4 年 1 月から平 成 13 年 1 月までに教室で施行された胆道癌肝切除 86 例のうち, 術前減 黄処置が施行された 38 例を対象とした.このうち体外にドレナージさ れた胆汁を腸管内に再注入した症例（施行群）は 4 例で，再注入非施行 例(非施行群)は 34 例であった. 胆汁は, 経鼻的に空腸まで挿入した ED tube を用いて，空腸内に再注入された，施行群における，再注入開始前 後の一日胆汁中総ビリルビン排泄量㧍よび減黄 $\mathrm{b}$ 值を比較検討し, ま た，施行群と非施行群の滅黄 $\mathrm{b}$ 値を比較検討し，滅黄における自己胆汁 再注入の有用性について考察した。ささに減黄開始時と手術直前の小野 寺 PNI (=10xアルブミン $+0.005 \mathrm{x}$ リンパ球数) の変化を, 施行群と非 施行群の間で比較検討し, 栄養維持における自己胆汁再注入の有用性に ついて考察した. 有意差の検定は t-testにより行った.【結果】施行群にお ける，一日胆汁中総ビリルビン排泄量は, 再注入前が平均 $156.6 \mathrm{mg}$, 再 注入後が平均 $222.3 \mathrm{mg}$ と, 有意差は認められなかったが再注入により増 加し, 減黄 $\mathrm{b}$ 值は, 再注入前が平均 -0.0113 , 再注入後が平均 -0.0265 と再注入により有意に滅黄率の上昇が認められた。非施行群の滅黄 b 值は平均 -0.040 で, 施行群の再注入前の減黄 $\mathrm{b}$ 值より有意に減黄率が 高く, 再注入後の滅黄 $\mathrm{b}$ 值とは有意差を認めなかった. 胆汁注入により 胆汁酸の腸肝循環が方進し胆汁量および循環回数が増加し, その結果隇 黄不良例の隇黄率が胆汁再注入により減黄良好な非施行群と同等に改 善したと考えられた. また, 施行群の小野寺 PNI は隇黄前が平均 43.36 , 手術直前が平均 43.82 で, 隇黄中の栄養状態は維持されていた.一方非施 行群の PNI は減黄前が平均 44.59 , 手術直前が平均 40.92 で, 栄養状態は 有意に低下していた．胆汁酸投与による脂肪吸収能の維持が栄養状態の 維持に関与していると考えられた.【結語】自己胆汁の再注入は, 減黄不 良例における減黄の改善に，また，滅黄期間中の栄養状態の維持に有用 と思われた

PS09-05 Hepatocyte Growth Factorによる胆汁うっ滞改善効果の 検討

大江秀明, 海道利実, 吉川 明, 森章, 今村正之

(京都大学医学研究科腫瘍外科)

【目的】肝胆萭領域の悪性腫瘍に起因する閉塞性黄疸に対する術前減黄 不良や肝門部胆管㿋などに対する肝切除後肝不全の一因として胆管炎 の合併が重要である. Hepatocyte Growth Factor (HGF) は, 肝再生促 進作用のみならず多彩な生物活性を有し, 我々は HGFによる肝切除後 胆汁うっ滞改善効果を報告した. 今回ラット肝内胆汁うっ滞性黄疸肝モ デルにおいて HGF による術前および術後減黄促進効果並びにその機序 につき検討した.【方法】黄疸肝モデルとして臨床における黄㾝軽減困難 例を想定し，胆管結禁等による閉塞性黄疸モデルではなく，胆管炎を惹 起し肝細胞性黄疸に近いとされる $\alpha$-naphthyl-isothiocyanate (ANIT) に

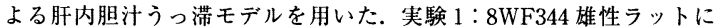
$\operatorname{ANIT}(75 \mathrm{mg} / \mathrm{kg})$ を腹腔内投与し黄疸肝を作製した. HGF 群には ANIT 投与時より 12 時間毎に human recombinant HGF (hrHGF：100 $\mu \mathrm{g} / \mathrm{kg}$ ) を投与し，24, 48 時間後の 1) 血液生化学検査, 2) 肝組織像, 3) cytokineinduced neutrophil chemoattractant (CINC) につき対照群と比較検討し た. 実験 2 : 実験 1 同様に黄疸肝を作製し，48 時間後，70\% 肝切除術を 施行した. HGF 群には肝切除 12 時間前より 12 時間毎に $\operatorname{hrHGF}(250 \mu \mathrm{g}$ $/ \mathrm{kg}$ ) を静注し, 肝切除 24,48 時間後の 1) 再生肝重量, 2) 肝再生能 (BrdU L. I. ），3）血液生化学検查，4）肝組織像につき対照群と比較検討した. 【結果】実験 $1: \mathrm{HGF}$ 群では対照群に比し 1) ANIT 投与 24 時間後で GOT, GPT, T-Bil の有意な低下，2) グリソン鞘周囲炎症細胞浸潤の軽減。 3）強力な白血球遊走因子である CINCの有意な低下が認められた. 実験 2：HGF 群では対照群に比し 1）再生肝重量は有意に高値，2）BrdU L. I. は肝切 24 時間後で著明に高值，3）T-Bilの速やかな低下，4）グリソ ン鞘周囲炎症細胞浸潤，細胆管浮腫が改善した.【結語】ラット黄疸肝モ デルにおいて HGF 投与により術前術後の胆汁うっ滞改善効果ならびに 肝切除後肝再生促進効果が認められ, HGF による抗炎症作用がその一因 と考えられた。 今後黄疸軽減困難症例に対する臨床応用が期待される.
PS09-06 生体肝移植術後の遷延性胆汁うっ滞一特にグラフトサイ ズ・原疾患との関連について

副島雄二, 西崎 隆, 皆川亮介, 廣重彰二, 永田茂行, 二宮瑞樹, 塩谷 聡子, 原田 昇, 末廣剛敏, 島田光生, 杉町圭蔵

(九州大学大学院消化器・総合外科 (第二外科))

【目的】肝移植後の胆汁うっ滞は様々な原因で起こりうるが, 生体肝移植 においては過小グラフトが原因と考えられる遷延性胆汁うっ滞, 難治性 腹水を特徴とする病態が報告されている (Small-for-size syndrome： SSS). 本病態の生体肝移植術後におけるグラフトサイズ, 原疾患との関 連，予後について検討した.【方法】九州大学における生体肝移植症例 50 例 (うち 2 例は再移植) を対象とした。原疾患の内訳は劇症肝炎 15 例, C 型肝炎 10 例，PBC 9 例，胆道閉鎖症 8 例, PSC2 例，その他 6 例で小 児 9 例, 成人 41 例であった. グラフトの種類は左葉 (+尾状葉) 42 例, 右葉 4 例，外側区域 4 例であった. グラフト・レシピエント理想肝重量 比 (GV/SLV) をもとにES (extra small) 群 $(\mathrm{n}=7): \mathrm{GV} / \mathrm{SLV}<30 \%$, $\mathrm{S}$ (small) 群 $(\mathrm{n}=10): 30-40 \%, \mathrm{M}$ (medium) 群 $(\mathrm{n}=26): 40 \%<に$ 分類し SSS の発生頻度, 予後を検討した. 原因不明の遷延性胆汁うっ滞 （術後 14 日の T. Bil > $5 \mathrm{mg} / \mathrm{dl}$ ) 及び難治性腹水（術後 14 日の腹水 $>1000$ $\mathrm{ml} /$ 日又は術後 28 日の腹水 $>500 \mathrm{ml} /$ 日）を認める症例を SSS と定義し た.【結果】50 例中 9 例 (18\%：PBC5 例，C 型肝炎 1 例, PSC1 例, 劇症 肝炎 1 例, 再移植 1 例：全例成人)に SSS を認めた. 9 例中 8 例は PBC, $\mathrm{C}$ 型肝炎などの慢性肝不全症例で劇症肝炎例は 1 例のみであった. グラ フトサイズ別にその発生頻度を見ると ES 群では慢性肝不全症例の $2 / 3$ $(67 \%)$, 劇症肝炎症例の $1 / 4(25 \%), \mathrm{S}$ 群ではそれぞれ $1 / 4(25 \%), 0$ /6 $(0 \%), M$ 群ではそれぞれ 5/21 (24\%)，0/5（0\%）であった. 全 9 例のグラフト生存率は $56 \%$ で平均入院日数は 74.7 日と他の症例 $(40.7$ 日)に比べて長い傾向にあった $(\mathrm{p}=0.08)$. 生存症例は最終的には肝機能 はほほ正常に回復, 腹水も消失し全例退院した.【まとめ】生体肝移植に おけるSSS は特に慢性肝不全に対する過小グラフトの使用で高頻度に 起こる. 最小必要グラフト容積は慢性肝不全では GV/SLV 約 $45 \%$, 劇症 肝炎では約 $30 \%$ と考えられ，慢性肝不全では劇症肝炎に比較してより 大きなグラフトを必要とする.

PS10-01 十二指腸負荷胆道内圧測定からみた傍乳頭息室合併総胆 管結石症の治療

永野靖彦, 関戸 仁, 藤井義郎, 長堀 薰, 渡会伸治, 嶋田 紘 (横浜)

（目的）傍乳頭憩室合併総胆管結石症に対する胆道負荷手術の適応を十 二指腸負荷胆道内圧測定法より検討する. (対象と方法) 1994 年 1 月から 1999 年 12 月までに術中胆道内圧を測定した総胆管結石症 40 例を対象 とし, 可変式定流灌流道内圧測定を施行した。横軸を灌流量, 縦軸を灌 流圧としてグラフを作成し，その傾きを $\mathrm{R}$ 值 (抵抗; 単位), 灌流量 0 の灌流圧を $\mathrm{P}$ 值 (残圧； $\mathrm{cmH} 2 \mathrm{O}$ ) として求めた。傍乳頭䄣室合併例は 17 例であり,これらには十二指腸内圧負荷による胆道内圧測定を施行し

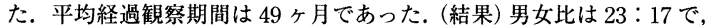
平均年齢は 59.6 歳 $(24-89)$ であった。総胆管結石の平均径は $10.8 \pm 5.0$ $\mathrm{mm}$, 平均個数は $4.4 \pm 5.2$ 個, 平均総胆管径は $14.4 \pm 4.4 \mathrm{~mm}$ であった. 1) 悡室合併例と非合併例の比較傍乳頭顖室合併例と非合併例を比較する と，合併例では $\mathrm{P}$ 值が $84.0 \pm 29.1 \mathrm{mmH} 2 \mathrm{O}$ であり，非合併例の $156.7 \pm$ $67.4 \mathrm{mmH} 2 \mathrm{O}$ に比較して有意に低下していた．R 值には有意差を認めな かった。また，結石成分を見ると憩室合併例では $81 \%$ の症例でビリルビ ン結石を認め, 非合併例の $35 \%$ に比較してビリルビン結石が多かった 2) 再発例, 胆管炎例術後再発例は 2 例, 術後胆管炎発症例は 2 例であっ た.これら 4 例は $\mathrm{P}$ 值 60 未満, $\mathrm{R}$ 值 2.5 未満の乳頭機能不全型または, $\mathrm{P}$ 值 160 以上， $\mathrm{R}$ 值 7 以上の乳頭狭窄型であった. 3) 十二指腸内圧負荷 胆道内压測定十二指腸内圧負荷前後の $\mathrm{R}$ 值差が 8 以上の 2 例は術後再 発, 胆管炎を認め, 一方 $\mathrm{R}$ 值差 8 未満の 14 例中 1 例に再発を認めるのみ であった.この 1 例は $\mathrm{P}$ 值， $\mathrm{R}$ 值ともに低い乳頭機能不全型であった. (結語) 傍乳頭㕷室合併例で十二指腸負荷前後の $\mathrm{R}$ 值の変化が 8 単位以 上の著明な増加を示す症例は十二指腸内圧が胆道系へ及ぼす影響があ るものと考えられ, 再発および術後胆管炎の危険因子であり, 胆道付加 手術の適応と考えられた. 
PS10-02 総胆管結石における内膜非貫通性クリップを用いた胆管 直接閉鎖術一実験的および臨床的検討一

篠塚 望, 斉藤直人, 浅野 博, 阿達竜介, 鈴木智晴, 上笹 直, 俵 英之, 小澤修太郎, 渡辺拓自, 松本 隆, 安西春幸, 小山 勇 (埼玉医科大学第 1 外科)

【目的】腹腔鏡下手術における胆管縫合は未だに一般的に普及している とは言えない. Vascular Closure Staple (VCS) は血管吻合における開存 率の向上と手術時間の短縮を目的に開発されたクリップで, 内膜非貫通 性という特徵をもつ. 今回基碟実験および臨床例においてVCSを用い て総胆管一次閉鎖を施行し，その有用性を検討した.【対象と方法】基礎 実験として計 21 例のラットの総胆管を結紮し閉塞性黄疸モデルを作 成, 7 日後に総胆管を切開し VCS にて閉鎖，7,28 日後に総胆管を摘出 し, 組織標本を作製した. ウサギではVCSにて総胆管を閉鎖した後酎圧 を測定した. 臨床例ではこれまで計 21 例にVCSによる総胆管直接閉鎖 を施行したが, 全例にCチューブを挿入し術中, 術後に胆道造影を行っ た.【結果】[実験]ラットでは胆汁の漏れはなく，縫合閉鎖に比較しきわ めて短時間に胆管閉鎖が施行できた. 7 日後および 1 ケ月後の病理所見 では, 胆管内腔の狭窄や壁肥厚を認めず, クリッブは胆管内腔に露出せ ず全例で開存を認めた。 また, ウサギの耐圧試験では, VCS 群はコント ロールの縫合閉鎖群と比較し, 明らかな酎圧の差を認めなかった。 [臨床 例]開腹手術においてはVCSによる閉鎖はきわめて容易であった. 腹腔 鏡下手術においては, VCS 本体を腹壁より直接挿入することにより, 全 例で総胆管切開部に到達可能であった。 また, 総胆管切開部の両端に牽 引系をかけることにより VCS 閉鎖が容易となった。術中Cチューブか らのリークテストで漏れが認めた部位には, VCSを追加することにより 確実な閉鎖が可能であった. 術後定期的に MRCPなどにて follow up しているが (最長観察期間 1 年 10 月)，これまで明らかな結石再発は認 めていない.【結語】これまでの検討からは，腹腔鏡手術における VCS による胆管閉鎖は, 手術時間の短縮や合併症の軽隇に有用と成りうる可 能性があると思われた. VCS は内腔非露出性のクリップであるが, 新た な結石形成への関与など今後さらに厳重な観察が必要と考える.

PS10-03当科における総胆管結石の治療選択

高金明典", 船渡 治", 大山健一 ${ }^{21}$, 藤原久貴 ${ }^{22}$, 秋山有史 ${ }^{21}$, 中屋 勉"，岡田晋吾"，貝塚広史"

(函館五稜郭病院外科", 岩手医科大学第 1 外科 ${ }^{21}$ )

【目的】当科において総胆管結石に対する腹腔鏡下手術が導入されたの は 2000 年 4 月からで，それ以前は Endoscopic sphincterotomy(EST)な らびに Endoscopic papillary balloon dilatation (EPBD) 施行後, 結石摘

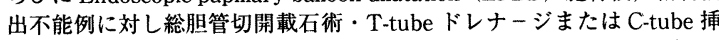
入法が施行された，腹腔鏡下総胆管切開術が施行されなかった理由は， 多数例で EST, EPBD により結石摘出が可能であった, 技術的な問題, 安 全性への懐疑, 手術時間延長等である.しかしながら, 技術の向上と多 施設報告により安全性が明らかとなり, 当科でも腹腔鏡下手術を採用す るに至った，そこで今後，総胆管結石の治療法をいかに選択すべきかに 関して, 我々が経験した症例をふまえて検討した.症例および術式】 2000 年 4 月から 2001 年 2 月までに当科で経験した総胆管結石に対する 腹腔鏡下手術症例は 4 例で, そのうち開腹に移行したのは胆裹炎による 炎症波及が高度な 1 例であった。いずれの症例も術前総胆管拡張を認 め, EST 等での結石摘出が困難な症例であった. 結石摘出にはバスケッ トカテーテルを用い, C-tube 㨂入後一期的総胆管閉鎖を施行した.【結 果】全症例で総胆管径 $10 \mathrm{~mm}$ 以上の拡張が認められ, 下部胆管に結石が 嵌頓していた. 平均手術時間は 254 分であったが; 3 例目においては 140 分と短縮された. 全例で術後 4 病日に総胆管狭窄や縫合不全の検索後 Ctube を抜去, 翌日退院となった。また合併症を認めず, 術後 QOL も良 好であった.【まとめ】総胆管非拡張例では通常結石は小さく, EST の小 切開で十分な治療効果が得られると考えられる.これに対し, 総胆管拡 張例では結石も大きく, EST を施行する際には大切開の必要があり,こ れに伴う乳頭機能不全や逆行性感染による結石再発が懸念される.した がって, 総胆管拡張例に対してはESTより腹腔鏡下胆襄摘出・総胆管 切開載石術を第 1 選択とすべきである.
PS10-04 胆管結石症治療における総胆管横切開一次閉鎖術の検討 山崎 徹, 北川裕久, 太田哲生, 荁原正都, 西村元一, 藤村 隆, 清水 康一, 三輪晃一

(金沢大学第二外科)

当科では胆管結石症に術中胆道内圧測定の抵抗值 $\mathrm{R}$ から乳頭機能を評 価して術式を選択している.すなわち乳頭機能正常例には胆道ドレナー ジなしに胆管横切開一次開鎖術 (以下一次閉鎖術) を, 乳頭機能異常例 には胆道ドレナージあるいは付加手術を施行する. 今回一次閉鎖術の利 点について Tチューブ捚入例と比較しつつ検討した. 一次閉鎖術の適応 は, 術中胆道内圧測定值が正常で, 胆道造影・内視鏡で異常がなく, 遺 残結石が無いことが確信される（近年の胆道内視鏡の進歩で完全切石が より容易になったため, 2000 年からは結石数による適応制限を除い た) 場合である. 本法は最近 10 年で 6 割前後に行われていたが適応拡大 に伴いさらに増加すると予想される，手術方法は開腹を基本とし，術中 胆道内視鏡, 胆道造影で遺残結石がないことを撖密に観察するため時間 は平均 160 分で, $\mathrm{T}$ チューブ挿入例とほほ同じであった. 本法の術後合 併症を前期（1985～1994 年），後期（1995〜2000 年）で比較した. 胆汁 漏出は, 短期間 ( 3POD) は前期 3 例 $(4.8 \%)$ 後期 1 例 $(3 \%)$, 長期間 (4POD〜) は前期 2 例 $(3 \%)$ 後期なしであった。後期では胆管切開部の 縫合に6-0モノフィラメント吸収系を使用したためと考えられる。 た術後肝機能障害は, 前期の 1 例 $(2 \%)$ にのみ, 遺残結石は前後期を通 じて 1 例も認めなかった. 平均的な一次閉鎖術, T -チューブ㨂入例の術 後入院期間は 16 日, 35.5 日で, 入院, 手術, 麻酔料は Tチューブ群は一 次閉鎖群に比べ 37,080 点高く, さらに注射, 処置, 検査料を加味すると 両群間の差は大きくなった. また最近一次閉鎖術は術後 7 日での退院を 目標に工夫している。 一次閉鎖術は合併症も少なく早期退院可能で，ま た医療経済面でもよい術式であると考えられた。

PS10-05 総胆管結石に対する治療方法の選択

大谷泰雄, 飛田浩輔, 堂脇昌一, 柏木宏之, 種田靖久, 金子順一, 石井 正紀，杉尾芳紀，石過たかふみ，津久井優，田中 豊，田島知郎，幕内 博康

(東海大学外科)

【目的】総胆管結石に対して，ESWLや EPBDや ENBD を用いた治療方 法を施行しているので報告する.【方法】総胆管結石による閉塞性黄疸に 对して non-EST 下に 5FrENBD を挿入し隇黄後に治療方針を決定して いる. 総胆管結石径が $10 \mathrm{~mm}$ 以内の症例は EPBD を施行し, 胆裹結石合 併例には腹腔鏡下胆震摘出術 (以下 LC) を追加した．胆摘術の既往があ り結石径が $10 \mathrm{~mm}$ 以上では EPBD または ESWLを施行した。結石径が $10 \mathrm{~mm}$ 以上で胆襄結石合併例では ENBD を用いた手術を腹腔鏡下・開 腹下に施行した. 1988 年 1 月から 2001 年 2 月までの総胆管結石 501 例 では, 非手術的 206 例 (EPBD117 例, EESWL62 例, EST18 例, PTCSL 6 例, ERBD 留置 2 例)，手術的 295 例（ENBD 手術 182 例〔開腹下 163 例 - 腹腔鏡下 19 例了 T-tube 挿入 83 例, 胆管空腸吻合術 9 例, PTBD 下胆管直接縫合術 8 例, 総胆管直接縫合術 8 例, ERBD 留置手術 4 例) 【結果】ENBD 手術の術後在院日数は開腹下 11.1 日・腹腔鏡下 8.3 日, Ttube 挿入 26.5 日, EPBD + LC12.3 日. 合併症は ENBD 手術では開腹下で 胆汁漏 1 例 - 遺残結石 1 例, 腹腔鏡下で胆汁漏 1 例. T-tube 扱入では, チューブ周囲の胆汁漏 3 例, 胆汁性腹膜炎 2 例. ESWL では合併症を認 めず. EPBD では 4 例に急性膵炎を認めた.【まとめ】 EPBD, ENBD, ESWL などの治療方法により在院期間の短縮や合併症の隇少に努めて いる. 
PS11-01 胆毫癌に対する HPD の成績と適応基準 太田岳洋", 吉川達也 ${ }^{22}$, 新井田達雄 ${ }^{2}$, 吾妻 司", 今泉俊秀", 高崎 健" (東京女子医科大学消化器病センター外科", 東京都立萑原病院外科 $\left.{ }^{21}\right)$ 目的】胆衰癌に対する HPD の意義を明らかにする.【対象】1968 年〜1999 年に教室で切除した深達度 ss 以上の進行胆赛癌 233 例中 $(\mathrm{H}) \mathrm{PD}$ を施行 した 95 例【方法】HPD 症例の手術成績を示し, 治瘾切除例の遠隔成績 を PD を併施しない 2 群以上郭清例と比較して苏頭周囲りンパ節郭清に 関する PD 併施の意義を検討する.【結果】HPD95 例の術式は肝葉切除+ PD 29 例 (右葉 28 例，左葉 1 例)，中央二区域 S4aS5 切除 + PD35 例, (肝床切除) +PD31 例であった. 手術死亡は 14 例 (14.7\%) に認め, 肝 右葉切除 +PD で 11 例 $(39.3 \%)$ と高率であったが, その他の肝切除 + PD では 3 例 $(4.5 \%)$ であった. 治瘾切除は 51 例 $(53 \%)$ で深達度別では

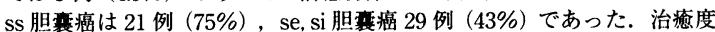
別の生存率では, 治癒切除は 3 生率 $49 \%, 5$ 生率 $43 \%$ と比較的良好で あったが, 非治癒切除では 3 生率 $8 \%$ であり, 5 年生存例はなかった。 HPD 治療切除例 51 例と PD を併施しない（nonPD）治瘾切除例で D2 以上郭清を行った 46 例の成績を, 胆裹癌の重要な子後規定因子である リンパ節転移 (n) と肝十二指腸間膜漫潤（binf）の二つの因子に注目し て比較した. $\mathrm{n}$ 陰性, binf 陰性の 32 例 (HPD 11 例, nonHPD21 例) では HPD 例の 3 生, 5 生率は $73 \%, 64 \%$ で nonPD の $85 \%, 78 \%$ と有意差は なかった。しかし n 陽性, binf 陰性の 29 例 (HPD18 例, nonPD11 例)で は HPD 例の 3 生, 5 生率は $72 \%, 67 \%$ で nonPDの $18 \%, 18 \%$ に対し て有意に予後良好であった $(\mathrm{p}=0.0367)$. しかし n 陰性, binf 陽性の 6 例 (HPD2 例, nonPD4 例) では両群に差はなく, n 陽性, binf 陽性の 28 例 (HPD18 例, nonPD10 例) では HPD 例の 3 生, 5 生率 $11 \%, 6 \%$ に 対し nonPD では $43 \%, 21 \%$ であり有意差はないが nonPD 例に予後良 好な傾向がみられた.【まとめ】 PD 併施による膵頭周囲リンパ節郭清が 遠隔成積向上に寄与することが示唆された. リンパ節転移陽性で, binf などの局所進展の少ない進行胆襄癌こそ HPD の良い適応である. 一方 あきらかな binf 陽性例や肝転移例は HPD を施行しても治癒切除は困難 であり，合併症も増えることから原則的には適応外と考える。

\section{PS11-02 HPD 手術を選択した胆道癌症例の検討}

伊藤 豊", 高野靖悟 ${ }^{2 \prime}$, 岩井重富 ${ }^{21}$, 原口義座 ${ }^{31}$

(日本大学第三外科, 国立病院東京災害医療センター第一外科"), 日本大 学第三外科 ${ }^{21}$, 国立病院東京災害医療センター臨床研究部 ${ }^{3}$ )

【目的】胆道癌に対する肝膡同時切除術（以下 HPD）の手術成績につい て検討した. 【対象】 90 年以来 HPD を施行したのは胆管癌 5 例, 胆裹癌 16 例であった. 胆管癌に対する肝切除量は肝床切除術 1 例, S4S5 切除術 1 例, 2 区域以上肝切除術 (Hr2) 3 例であった. 胆裹癌には肝床切除術 7 例, S4S5 Hr2 未満切除術 4 例, $\mathrm{Hr} 2$ 以上 6 例であった. 䐙再建術は 92 年以前は羘腸吻合, 93 年以降は直視下腪胃吻合を選択した. 93 年を前 期, 以降を後期症例として比較検討した. 胆管癌はいずれも広範囲浸潤 型で, そのうち 2 例が同時肝転移例を認めた. 胆貫癌（ss 5 例 se 2 例 si 9 例）の深達度別の肝切除量はss 症例が肝床切除術 4 例, Hr2 以上 1 例, se 症例が肝床切除術 1 例, Hr2 以上 1 例, si 症例が肝床切除術 2 例, S4S5 Hr2 未満切除術 3 例, $\mathrm{Hr} 2$ 以上 3 例であった.【成績】手術関 連死は 6 例 $(23.8 \%)$. 肝切除量からみると肝床切除 $2 / 8$ 例, $\mathrm{Hr} 2$ 末満 1 $/ 5$ 例, $\mathrm{Hr} 2$ 以上 $3 / 9$ 例であり 2 区域未満の症例の死亡は䐙縫合不全に起 因していた，手術時期別では前期 4/8 例 $(50 \%)$ ，後期 $2 / 13$ 例 (15.3\%) であった. 前期死亡症例は䐙縫合不全を 3 例認め, 死因は MRSA 敗血症 1 例, 肝不全 2 例, 腹腔内出血 1 例であった。後期死亡症例は捇縫合不全 を認めず死因は肝不全 1 例, 肺炎 1 例であった. 胆管癌は同時肝転移を 認めた 2 例は半年以内に死亡し, 酎術例の深達度 se 症例が 19 か月後肝 転移にて死亡, 深達度 $\mathrm{fm}$ 症例が無再発経過している. 胆赛癌の深達度 se 以上の症例には 3 年生存例を認めなかった. ss 症例の周囲進展度は hinf0 1 例 hinf1 1 例 hinf2 2 例 hinf3 1 例で binf 陽性例を認めなかった. ss 症例の 5 生率は $80 \%$ で, 根治度別では根治度 A 4 例が無再発に経過 中である. 根治度 C 症例は, 大動脈周囲リンパ節転移陽性の 1 例で 4 か月後死亡した.【まとめ】HPD の胆管癌に対する適応は肝転移, 大動脈 周囲リンパ節転移のない広範囲浸潤型で尾状葉を含む肝葉切除術が必 要. 胆串㿋は深達度 ss 症例のうち大動脈周囲リンパ節転移のない hinf2 以下レベルの症例において bm, hm, em が十分とれる肝床切除を加える ことにより長期生存が期待できると考えられた。
PS11-03胆道癌における HPD の検討

石川忠則, 堀見忠司, 岡林孝弘, 市川純一, 西岡 豊, 長田祐典, 濱田 円, 渋谷祐一, 甫喜本憲弘, 小坂芳和

(高知県立中央病院外科)

【目的】進行胆道癌において当院で施行された HPD 症例の進行度, 予後 を検討し, その適応と限界を明らかにする.【対象】HPD の肝切除は, 亜 区域切除や肝床切除は含まないものとし，1986 年 4 月から 2001 年 1 月 までの約 15 年間に進行胆道癌において HPD を施行された症例は 15 例 で, 肝門部胆管癌 8 例, 胆裹癌 7 例であった. 平均年齢は 65.1 歳, 男女 比は $10: 5$ であった. 対照として, PD を伴わない肝切除を施行した肝門 部胆管癌 27 例, 胆裹癌 12 例を対象とした. 【結果】stage は肝門部胆管癌 で, II $: 1$, III $: 2$, IVa $: 1$, IVb $: 4$ 例, 胆襄癌 で, III $: 1, \mathrm{IVa}: 5, \mathrm{IVb}: 1$ 例であった. 肝切除の内訳は, 拡大右葉 + 尾状葉切除 1 例, 拡大左葉 + 尾状葉切除 1 例, 左葉 + 尾状葉切除 6 例, S4a+S5 切除 3 例, S4a+S5 $+\mathrm{S} 6$ 切除 2 例, 内側区域 + 尾状葉切除 2 例であり, 門脈は 4 例で合併切 除再建, 肝動脈は 2 例で合併切除, 1 例で再建された. HPD 施行の理由 として, 肝門部胆管癌では, 腪, 下部胆管進展 $: 6$, リンパ節廓清 $: 2$ 例, 胆襄癌では十二指腸浸潤 : 3 , リンパ節廍清 $: 3$, 胆管進展 $: 1$ 例, であっ た. 治癒切除は肝門部胆管癌で 6/8 $(75.0 \%)$, 胆裹癌で $5 / 7(71.4 \%)$ で あった. 在院死は 3 例 $(20.0 \%)$ で, 何れも肝門部胆管癌症例であった. 2 年, 5 年生存率は, それぞれ, 肝門部胆管癌で $25.0 \%, 25.0 \%$ で, 胆裹 癌で $28.6 \%, 14.3 \%$ であった. 長期予後は, 5 年 5 ケ月生存および 5 年 8 ケ月死亡であった. 比較として, 肝切除を施行した肝門部胆管癌 27 例, 胆裹癌 12 例の治癒切除率は, それぞれ, $12 / 27(44.4 \%), 6 / 12(50.0$ $\%$ であり, 2 年, 5 年生存率は, それぞれ，肝門部胆管癌で $35.9 \%, 15.0$ \%で, 胆輷癌で $26.7 \%, 0 \%$ であり, HPD 症例と統計学的有為差は認め なかったものの, HPD 症例の治瘾切除率および 5 年生存率の高い傾向を 認めた. [結語]進行胆道癌において, HPD は治癒切除率の向上および長 期予後を得る可能性が示唆された.

PS11-04当科における胆道癌 HPD 症例の検討

増成秀樹, 遠藤 格, 藤井義郎, 杉田光隆, 田中邦哉, 関戸 仁, 渡会 伸治, 嶋田 紘

(横浜私立大学第 2 外科)

【目的】教室では進行胆道癌の治痛切除を目指して, 肝膵同時切除 (HPD) を施行してきた。しかし, 合併症の発生率は高く十分な治療成績は得ら れていない. 今回自験例を検討し, 術式選択について考察した.【方 法】1992 年 4 月から 2000 年 12 月に施行した HPD 10 例を対象とした. 疾患は胆囊癌 4 例 (stageIVa (3), IVb (1)), 胆管癌 6 例 (stageI (1), II (1), III (1), IVa (2), 再発 (1) ) で, 平均年齢 67 歳であった. HPD の施行理由は, 胆囊癌では䐙十二指腸への直接浸潤 3 例, 㫫頭部リンパ 節の郭清目的 1 例で, 胆管癌では再発症例を除き全例広範囲胆管進展の ためであった，肝切除範囲は，右葉十尾 (1)，(拡大) 左葉 +尾 (3), 内 側区域＋尾 (1), S4aS5+尾 (2), 肝床部 (2), 尾状葉単独 (1) で 1998 年以降, 根治性を確保しつつ縮小肝実質切除を行うようにしている. 血 管合併切除は 6 例（動脈 5, 門脈 3）に施行した.【結果】総合的根治度別 症例数は curA (1)，B (4)，C (5) で, 平均生存期間は 10.4 ケ月であっ た. 術後早期合併症を 9 例 (肝不全 (2), 肝膿場 (2), 腹腔内出血 (1), 胆汁度 (4), 縫合不全 (5), 腹腔内膿演 (1), その他 (2)) に認めた。こ のうち上部胆管癌に対する右葉 +尾 (切除率 $70 \%$ ) 後の肝不全症例, 再 発胆管癌に対する拡大左葉＋尾 $(68 \%)+$ 肝動脈合切非再建後の肝膿瘍 - 肝不全症例, 肝門部胆管癌に対する左葉 +尾 $(30 \%)$ ，動門脈再建 (ルーペ)後の肝膿鹪症例の 3 例が在院死亡となった．縮小肝実質切除の 3 例（内側区域＋尾（1）, S4aS5+尾（1）, 尾状葉単独（1)）には重篤な 術後合併症はなく,このうち curB が得られた 2 例は術後 12 ヶ月, 30 ヶ月無再発生存中である.【まとめ】HPD において 2 区域以上の肝実質切 除および血行再建は重篤な術後合併症に直結するため, 避けるべきであ る. 根治性を損なわずに手術侵襲の軽滅をはかるため, 過不足のない縮 小肝実質切除を行うことが必要と思われた。 


\section{PS11-05}

胆管癌・胆襄癌に対する肝腆同時切除術の成績からみた 適応と対策

星野実加, 阿部 幹, 齋藤拓朗, 土屋貴男, 佐藤佳宏, 見城 明, 山田 文彦, 後藤満一

(福島県立医科大学第一外科)

【目的】胆管癌・胆褧癌に対して根治性を求めて肝膵同時切除 (HPD) の 術式を選択することが增えてきているが, 依然術後合併症率が高いこと が問題である. 今回胆管癌・胆囊癌に対して HPDを施行した症例の成 績から HPD の適応と対策について考察した.【対象・方法】 2000 年 12 月までに経験した HPD 症例は 20 例で, 胆霊癌 8 例, 胆管癌 11 例, 胆震 癌・胆管癌合併例 1 例であった. 肝切除術としては 2 区域以上切除が 13 例 (右葉切除; 7 例, 左葉切除; 5 例, 肝中央 2 区域切除; 1 例), 肝 4 下 +5 切除が 3 例, 肝門部切除が 2 例, 拡大胆摘が 2 例で, 腪切除術とし ては幽門輪温存膵頭十二指腸切除術が 12 例であった.これら 20 例を対 象とした.【結果】1) 合併症：術死 1 例, 在院死 6 例で, 死因は肝不全 3 例, 癌死 3 例, 縫合不全 1 例であった. 術後肝不全と肝切除量には有意 な相関は認めなかったが, 肝不全の 3 例はいずれも肝 2 区域以上の切除 例であった．術後肝不全と䐙吻合部释合不全には有意の相関が認めら れ，蓃吻合部縫合不全は肝不全の誘因の一つと考えられた，術後に腹腔 内感染症を併発した症例は 12 例で, この内術前胆汁培養で陽性であっ た 8 例中 6 例は腹腔ドレーンからも同一菌が検出された. 2) 術後成績： 全症例の $50 \%$ 生存期間は 21 ケ月（胆管癌： 28 ヶ月, 胆䔩癌: 5 ケ 月) で, 治癒切除例 $(n=12)$ と非治癒切除例 $(n=8)$ の生存期間には有 意差 $(\mathrm{p}<0.05)$ を認めた．しかし治瘾切除例のみでは, 胆管癌と胆营癌 の生存期間に有意差はなかった. 非治癒切除 8 例中 6 例は 6 ケ月以内に 死亡した. 6 ヶ月以内の死亡例は 9 例 (治癒切除 3 例, 非治癒切除 6 例) で, そのうち癌死は 4 例（治癒切除 1 例, 非治痖切除 3 例）であった. 【結語】1) HPD の適応は治癒切除症例に限られるが, 生物学的悪性度の 高い胆囊癌への適応は慎重にすべきと考えられた．2)術後肝不全の誘因 である茀吻合部縫合不全の対策として, 安全性の高い滕胃吻合を優先的 に選択し, 腹腔内感染症の対策としては, 術前に胆汁培盖を施行して起 因菌を同定し薬郕感受性を調べておくことが重要であると考えられた。

PS11-06 肝膵同時切除 (肝葉切除＼cjkstart腪頭十二指腸切除) の適応と成 績

黑崎 功, 畠山勝義, 二瓶幸栄, 河内保之, 横山直行, 白井良夫, 佐藤 好信, 青野高志

(新潟大学第 1 外科)

【目的】肝膵同時切除は胆道癌治療におけるもっとも侵襲の大きな切除 法であり，その適応は厳格でなければならない。本研究では(全胃温存) 膵頭十二指腸切除に 2 区域以上の肝葉切除（HPD）が施行された胆道癌 症例ついて, 適応と成績を検討し考察を加えた. 【症例と方法】過去約 20 年間に当科にて施行した HPD 16 例 (胆管癌 8 例, 胆囊癌 8 例) を対象と した. 肝切除の内訳は, (拡大) 右葉切除 15 例, 左葉切除 1 例であった. 門脈合併切除. 下大静脈部分切除が各々 2 例で施行された. 検討項目は 腫場の発育進展の特徵および術後成績であり, 病理学検討は胆道癌取り 扱い規約に準じた。なお，12 例は術前に閉塞性黄㾝を認めた。【結果】平 均手術時間は 740 分, 平均術中出血量は $2700 \mathrm{ml}$ であった. 術後 2 月以内 の手術死亡は 2 例で, 何れも胆管癌であった. 胆襄癌 8 例中 6 例は $\mathrm{t} 4$ で, $\mathrm{t} 3, \mathrm{t} 2$ が各々 1 例であり, 肝門浸潤型は 2 例, 膵頭部背面への広範囲 の間質浸潤を伴うものは 3 例であった.リンパ節転移は 6 例（全て $\mathrm{n} 2$ 以上) で, 平均 3.2 個の転移リンパ節を認めた. No16 転移を 2 例で, 根 治度 $\mathrm{C}$ は 3 例であった, 胆管癌 8 例は上中部原発 7 例で肝門部原発が 2 例であった. $\mathrm{t} 2: 5$ 例, $\mathrm{t} 3,4: 3$ 例であり, 1 例を除き $\mathrm{pn} 3$ であった.リ ンパ節転移は 6 例で認め (平均 3.6 個), $\mathrm{n} 2(+)$ は 3 例で, Nol6, Nol4

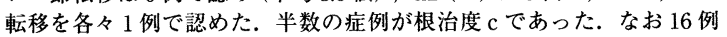
中, $\mathrm{t} 2$ 胆霊癌の 1 例を除き, HPD は病変切除のための絶対適応であっ た. 術後成績は, 胆裹癌では 2 例が 3 年以上, 3 例が 1 年以上生存したが, 何れも根治度 b 以上の症例であった. 胆管癌（耐術 6 例）では, No14 転移の 1 例が 7 年以上生存中であるが, その他 2 年 3 月生存例を除き 4 例は 1 年以内に死亡した.【まとめ】HPD を要するような胆道癌では, 高 度の局所進展のみならず, 広範囲のリンパ節転移や間犋浸潤を伴う場合 が多く, 予後は不良であった. 今後さらに治癒切除率の向上と補助療法 が必要と考えられた。
PS12-01再発形式からみた肝門部・上部胆管癌に対する術後放射 線療法の治療効果と限界

神谷紀之", 遠藤 格", 增成秀樹", 瀧本 篤" ${ }^{2}$, 藤井義郎", 関戸 仁"，渡会伸治"，嶋田 紘"

(横浜市立大学第 2 外科", 稲田登戸病院 ${ }^{21}$ )

【目的】肝門部・上部胆管癌切除例に対する術後放射線療法 (PORT) の 治療効果と再発例の分析を行い, PORT の限界を考察した. [方法】 7 年 6 ケ月間に切除術を行った肝門部・上部胆管癌 31 例の臨床病理学的予 後規定因子および再発例の背景因子を検討した。 また切除標本の免疫染 色から p53 蛋白の発現と, PORTの治療成績との関係を検討した. 【結 果】 全症例の 3,5 年生存率はそれぞれ $49.7 \%, 36.3 \%$ で, 予後規定因子 (多変量解析) は $\mathrm{n} 2$ 以上のリンパ節転移, PORT の有無と根治度であっ た. PORT の適応は根治度 B, Cとしていたが, PORT (+) 群 21 例と PORT $(-)$ 群 10 例の間に術式・組織学的根治度・ $\mathrm{n} \cdot$ stage 等の背景因 子に差はなかった．また全例根治度は切除縁により規定された。根治度 /PORT 有無別 1, 3 年生存率は, 根治度 A, B/PORT (+) 群 100, $80 \%$, $\mathrm{A}, \mathrm{B} /(-)$ 群 $60.0,40.0 \%, \mathrm{C} /(+)$ 群 $100,43.8 \%, \mathrm{C} /(-)$ 群 40.0 \%で, 根治度 Cでも PORT (+) 群は A, B と同等の生存率だった. PORT $(+)$ 群の再発形式は, 遠隔再発 3 例, 胆管断端 2 例, 腹膜播種 3 例, No. 16 リンパ節 1 例で, PORT (-) 群の遠隔 2 例, 腹膜 4 例と比べ腹膜播 種再発が少なかった. PORT (+) 群のうち $\mathrm{dm} 2$ と $\mathrm{hm} 2$ の 8 例中 3 例は PORT は無効で局所再発を認めたが $\mathrm{dml}, \mathrm{hml}$ からの局所再発はなかっ た. $\mathrm{dm} 2$ と $\mathrm{hm} 2$ の PORT 無効例は全例 $\mathrm{p} 53$ 陽性だったが有効例の 5 例中 4 例は p53 陰性であった. em1, 2 ではPORT (+) 群の 12 例中腹膜 再発を各 1 例認め, いずれも $\mathrm{pn} 2$ かつ $\mathrm{n} 2$ であったが $\mathrm{p} 53$ との関連性は なかった. em 1,2 のPORT $(-)$ 群では 9 例中 6 例に腹膜再発を認めた. 【結論】肝門部・上部胆管癌に対する PORT は補助療法として有用と考 えられた. しかし PORT 後は $\mathrm{dm} 2 や \mathrm{hm} 2$ の $\mathrm{p} 53$ 陽性例では局所再発, $\mathrm{em} 1,2$ では $\mathrm{pn} 2$ 以上かつ $\mathrm{n} 2$ 以上で腹膜再発のリスクが高いため, 大動 注療法や全身化学療法の併用が必要と考えられた。

PS12-02 肝門部胆管癌切除療法の根治度規定因子と術後照射療法 の検討

竹内丙午, 鈴木正徳, 海野倫明, 片寄 友, 松野正紀

(東北大学第 1 外科)

肝門部胆管癌の外科的切除療法の成績は, 他の消化器癌の成績と比較し 満足すべきものであるとは言えない. 肝門部の胆管の解剖学的理解の深 化に則った尾状葉切除の併施など, 肝門部胆管癌の切除療法の根治度を 高める努力がなされているにもかかわらず, 病期が進行して発見される ことが多いため, 治癒切除率が低いことが原因の 1 つと考えられる. わ れわれは自験例で胆管癌の切除の根治度を左右する因子を検討し，あわ せて術後補助療法としての照射療法の効果と意義を検討した. (方法) 1965 年 12 月より 2000 年 12 月に切除術施行した肝門部胆管癌 91 例. 症 例を総合的根治度规定因子別に Kaplan-Mayer 法による累積生存率を計 算し比較した. (結果) 総合的根治度： curA, curB, curCはそれぞれ 21 例, 37 例, 33 例で 1 年生存率は $90.5 \%, 48.6 \%, 36.4 \%, 3$ 年生存率は 23.4 $\%, 13.5 \%, 6.1 \%$ で curA は B, C と比較し有意に高い. 根治度 A が得ら れない要因としては, curB $+\mathrm{C}$ 群 (70 例) では, $\mathrm{D} \leqq \mathrm{n}$ が 13 例（18.3 $\%), \mathrm{hm} \geqq 1$ が 41 例 $(58.6 \%), \mathrm{dm} \geqq 1$ が 6 例 $(8.6 \%), \mathrm{em} \geqq 1$ が 58 例 (82.9\%) で em が確保できない case が多かった. 術式別の検討では右 葉, 左葉, 肝門部, 胆管切除の根治度に有意の差が認められなかった。 $\mathrm{CurB}+\mathrm{C}$ 群の $\mathrm{hm0}$ と $\mathrm{hm} 1+2$ の 1 年生存率はそれぞれ $55.2 \%, 34.1 \%$, 3 年生存率 $6.9 \%, 12.2 \%$ で有意差はなかった。一方 curB +C 群の $\mathrm{em} 0$ と $\mathrm{em} 1+2$ の 1 年生存率はそれぞれ $63.6 \%$ と $48.3 \% 3$ 年生存率 $18.2 \%$, 10.3\% で em0 は有意に生存率が高かった. CurC の 4 例 ( hml 以上 3 例, em1 以上 3 例）に術後体外照射が追加された．生存期間は $10 \sim 21$ 月 (平均 15.8 月) 1 例が他病死, 3 例が癌性腹膜炎による腫瘍死で横断再 発例は無かった。 (総括) 胆管癌切除では剥離断端の癌浸潤の陰性を得る ことが困難で予後を左右する一方, 肝側断端とくに $\mathrm{hml}$ は予後規定因 子として重要でない.また非治瘾切除症例に対する術後照射は em 陽性 がもたらす腹膜播種には効果がなく, 術後補助療法としての意義は少な いものと考えられた. 
PS12-03当科における胆管癌の術後放射線療法

千葉英男, 安田是和, 石橋敏光, 仁平芳人, 北條宣幸, 山下圭輔, 永井 秀雄

(自治医科大学消化器・一般外科)

(はじめに) 画像診断技術および手術手技の進歩により，胆管癌の治癒切 除率は向上してきているが，依然として予後不良の癌である，予後を悪 化させる要因として, 非治瘾切除, リンパ節転移, 遠隔転移・腹膜播腫 などがある，また胆管断端の癌浸潤も術後再発から閉塞性黄㾝をきた し, 予後を悪化させうる要因と考えられる.このため我々は, 肝側断端 の癌浸潤が問題となる中部・上部・肝門部・肝内胆管癌に対し, 術後積 極的に体外放射線療法を施行している. 今回, 胆管癌に対する術後放射 線療法の成績，病理学的所見を検討した. (結果) 1991 年 1 月より 2000 年 12 月の 10 年間に当科で胆管切除を施行した胆管癌症例は 91 例で あった. 91 例中術後 6 週以内に放射線療法を開始した症例は 28 例 $(30.8$ \%) であった. 28 例の年齢は 42 から 86 歳 (平均 64.6 歳) で, 男女比は $16: 12$ であった。放射線量は $32 \mathrm{~Gy}$ から $60 \mathrm{~Gy}$ ，平均 $50.3 \mathrm{~Gy}$ であった。 放射線療法に起因すると思われる合併症は軽度の白血球減少を 2 例に 認めるのみであった，癌の占拠部位でみると，主占拠部位が $\mathrm{Bm} 12$ 例 $(42.9 \%), \mathrm{Bs} 8$ 例 $(28.6 \%), \mathrm{Bl} 4$ 例 $(14.3 \%), \mathrm{Br} 2$ 例 $(7.1 \%), \mathrm{Bs}-\mathrm{m}$ 2 例 $(7.1 \%)$ であった。病理学的所見では, $\mathrm{hm} 212$ 例 $(42.9 \%), \mathrm{hm} 1$ 3 例 $(10.7 \%), \mathrm{hm} 013$ 例 $(46.4 \%)$, em2 5 例 (17.9\%), em16 例 $(21.4$ $\%)$, em0 11 例 $(39.3 \%)$, em 不明 6 例 $(21.4 \%)$ であった. 予後をみる と追跡しえた症例は 25 例で，1 年，3 年，5年生存率はそれぞれ $88.2 \%$, $50.0 \%, 25.0 \%$ であった. (まとめ) 当科における胆管癌の術後放射線療法 の結果と病理学的所見を検討した. 術後体外放射線療法は予後を改善さ せる, という結果は得られなかった. 今後, 術後補助療法として, 予後 を改善させる治療法の検討が必要であると思われた。
PS12-05

討

岩本充彦, 森田眞照, 左古昌蔵, 土肥健彦, 井上 仁, 原均, 谷川允 彦

(大阪医科大学一般・消化器外科)

【目的】胆囊癌症例は進行例が多く, 切除後に再発や転移を来し予後不良で ある. 従って, 術後周術期の治療法に期待するところが大きい. 今回, 胆 囊癌症例に扔ける周術期化学療法の有効性について検討したので報告す る.【対象と方法】過去 22 年間に教室で経験した胆囊癌は 107 例で, 手術的 根治度 B 以上の胆瑾癌 56 例（CurA43 例，CurB13 例）を対象とした．局 所進展様式を組織学的癌深達度と肝および胆管への浸潤形式より I 群 (m or mp, hinfo, binfo), II 群 (ss, hinfla, binf1), III 群 (se or si, hinf1b 以上, binf2 以上)の 3 群に分け検討した.【結果】I群は 17 例, II 群は 27 例, III 群は 12 例で, 施行術式は, I 群が胆摘 12 例, 胆摘と肝床切除 3 例, 肝覀区 域切除 2 例で, リンパ節郭清 (D1 2 例, D2 5 例, D3 1 例) 8 例に, II 群が 胆摘 8 例, 肝床切除 15 例, 肝带区域切除 4 例で, リンパ節郭清（D2 15 例, D2 + LN16 9 例, D3 1 例) 25 例に, III 群が肝床切除 3 例, 肝床切除と PD4 例, 肝亜区域切除 1 例, 拡大肝右葉切除 1 例に, 拡大肝右葉切除と PD 1 例に, リンパ節郭清 (D2 4 例, D2 + LN16 3 例, D3 5 例) 12 例に行った. 周術期化学㙩法施行例は, I 群 : 0 例, II 群 : 16 例, III 群 : 6 例であった. その内容は, 主として MMC と FT207 の併用または low dose CDDP と 5FU の併用療法であった. 再発例はI 群には認めなかった. II 群が 5 例(根 治度 $\mathrm{A}: 3$ 例, 根治度 $\mathrm{B}: 2$ 例) で, 再発様式は, 肝再発が 4 例, 局所再発 が1例であり,すべて周術期化学療法を施行していなかった.また 5 年以 上生存例 13 例のうち 11 例に周術期化学療法を施行していた. III 群の再 発例は 9 例 (根治度 $\mathrm{A}: 3$ 例, 根治度 $\mathrm{B}: 6$ 例) で, 肝再発が 3 例, リンパ 節再発が 3 例, 癌性腹膜炎が 3 例であり, このうち周術期化学療法を施行 したは 3 例（根治度 A $: 1$ 例, 根治度 B : 2 例) であった。また, 5 年以上 生存例は 2 例に認め, いずれも周術期化学療法を施行した根治度 A 症例 であった【結論】胆囊癌の周術期化学療法は, 局所進展度 I 群では不要で ある. 一方, II および III 群では必要であり，II 群および III 群の根治度 A には, 遠隔成績の向上に寄与するものの, III 群の根治度 Bには, さらに有 効な集学的治療が必要であると考えられた.

PS12-06胆囊癌における TSおよび DPD 活性の解析 味木徹夫", 羽原一登", 神坦 隆", 中村 毅"), 具 英成 ${ }^{11}$, 黑田嘉 和"，小野山裕彦"

(神戸大学第 1 外科", 済生会中津病院外科 ${ }^{2}$ )

【目的】胆道癌に対する補助化学療法として現状では 5-FU 系抗㾔剤が使 用されているが，その奏効率は満足できるものではない，我々はこれま でに, 胆道癌細胞株は他の消化器癌細胞株にくらべ有意に5-FU 抵抗性 を示し, 5-FUの target enzyme である thymidylate synthase (TS) 活性 は他の消化器癌細胞株の 3.1 倍高く, 5-FU の分解酵素である dihydropyrimidine dehydrogenase（DPD）活性は他の細胞株と差がなかったこ とを報告してきた. 今回，臨床検体での TS, DPD 活性を検討したので報 告する.【対象と方法】 1) 切除進行癌 22 例（胆襄癌 4 例, 胃癌 9 例, 大 腸癌 9 例)につき，患者同意を得た後，その凍結材料を用いて，binding assay 法により TS 活性を，TLC 法により DPD 活性を測定した．2）胆 整癌 52 例の切除標本のホルマリンブロックを用い, TS 蛋白発現を免疫 組織学的に検討した. TS 発現の評価は $25 \%$ 以上の癌細胞に染色される ものを TS high, $25 \%$ 未満のものを TS low とした. 【結果】1) 凍結材料の TS 活性の平均値は胆囊癌で $0.070 \mathrm{pmol} / \mathrm{mg}$ で, 胃癌 0.035 , 大腸癌 0.052 にくらべ高值を示した．DPD 活性の平均值は胆囊癌で $210 \mathrm{pmol} / \mathrm{min} /$ $\mathrm{mg}$ であり, 胃癌 131 , 大腸癌 67 に比べ有意に高值であった $(\mathrm{p}<0.05)$. 2) 胆霟癌切除例では早期癌で TS low / high $=9 / 3$, 進行癌で TS low/high $=16 / 24$ と進行癌で有意にTS high 症例が多かった $(\mathrm{p}=0.049)$.【まと め】 TS 活性は胆囊癌の進展で亢進し, 胃大腸癌に比し高い傾向を示し た. DPD 活性は細胞株のデータと異なり, 胆囊癌では胃大腸癌に比し元 進していた. 以上から, 胆道癌での 5-FU 系抗癌剤の低い奏効率が, 胆道 癌自身の進展に伴う TS および DPD 活性高值に起因する可能性が示唆 された。 
PS13-01 腫瘤形成性膵炎自験 13 例における爁別診断および治療 成績に関する検討

福田 晃, 今泉俊秀, 原田信比古, 羽鳥 隆, 高崎 健

(東京女子医科大学消化器外科)

【目的执よび対象】画像診断の進歩した現在においても腫瘤形成性腪炎 と䐙癌の鑑別に難渋することが少なくない. 今回我々は 1990 年 1 月以 降教室で経験した䐙頭部腫瘤形成性满炎 13 例を対象に画像診断 (CT, ERCP, 血管造影, US, EUS) の所見および治療成績について検討を行っ た. 年齢は 40-67 歳 (平均 48.7歳), 男女比は $11: 2$ であった。成因は アルコール性 11 例, 特発性 2 例である。病悩期間は 2 ヶ月 -12 年 (平均 2 年 8 r月) で, 主訴は腹痛 10 例, 黄㾝 1 例, 食欲不振 1 例, 無症状 1 例であった. 術前の荤外分泌機能は正常 3 例, 低下 10 例で, 耐糖能は正 常 3 例, 境界型 5 例, 糖尿病型 5 例であった. 【結果】CT では腫瘤は造影 早期で非病巣部と同等に均一に濃染された症例 6 例 $(46 \%)$, 不均一に濃 染された症例 7 例 $(54 \%)$ であった，血管造影では䐙内動脈を中心にほ ほ全例に広狭不整および蛇行を認めたが, 動脈の閉塞, 途絶像は認めな かった. ERCPでは主䐙管の拡張を 10 例 $(77 \%)$, 膵管系の狭窄を 8 例 $(62 \%)$ に，萭内胆管の狭窄を 7 例 $(54 \%)$ に認めたが，いずれも平 滑な狭窄であった. US およびEUS では 11 例 $(85 \%)$ で内部が不均一な 低エコー腫瘤として認められ, penetrating duct sign は 3 例 (23\%) で認 められた. 治療は全例に手術が行われ, 胃癌を合併した 1 例にPD が行 われたが, 11 例に PpPD, 1 例に十二指腸温存荤頭切除術が施行された. 術前に腹痛を有した症例全例で術後疼痛は消失し, 術後の䐙外分泌機能 は 12 例 $(92 \%)$ ，耐糖能は 12 例 $(92 \%)$ で術前と同等に保たれていた。 【結語】腫瘤形成性䐸炎の鑑別に際しては造影 CT での造影効果, 血管造 影での途絶像の有無, ERCP での膵管の狭窄形態, US での内部不均一な 低エコー腫瘤および penetrating duct signなどから総合的に判断する ことが大切であると考えられた．また，完全に悪性腫場が否定できない 症例も少なくない以上, 荤切除術が基本的治療と考えられ, 除痛効果, 䐙内外分泌機能の温存の面からみても膵頭切除術は有効な治療法で あった。

PS13-02

画像所見からみた腫瘤形成性腪炎と膵癌の鑑別点につい

星野光典, 石井 博, 中村明央, 伊達 淳, 富永幸治, 小池 康, 大堀 真毅，大山 祥，榎澤哲司，太田 篤，小池礼子，草野満夫

(昭和大学一般・消化器外科)

【目的】腫瘤形成性膵炎 (TFP) は, 膵に限局性の腫瘤形成をきたす满炎 とされ, 腫瘤による総胆管や十二指腸の狭搾を呈する症例もみられ, 画 像上䡔癌との鑑別が極めて困難である. 今回, 我々は TFP と切除膵癌 (PC)を対比し, 主に画像所見における両者の鑑別点について検討した. 【対象・方法】切除標本もしくは術中凍結標本にてTFP と診断された 8 例と PC 15 例で, 方法は両者の血液生化学的所見, US, CT, ERCP, 血管 造影所見について検討した。有意差検定は分割表分析 T2 乗検定で行っ た.【結果】1.患者背景：TFP 8 例の部位は頭部 7 例，体部 1 例で術式は DP, PD 各 1 例, PpPD4 例, 術中凍結標本で慢性荤炎と診断された 2 例は 胆管空腸吻合術を施行した. PC の部位は全例頭部で PD8 例, PpPD7 例であった.2. 血液生化学検查所見：TFP では捇腫瘤が大きいにも関わ らず, 腫瘍マーカーの多くは陰性であった. 3. US：TFP と PC はほとん どの例で echo level は low から iso で, TFP 8 例のうち duct penetration sign や ductal structure は 6 例にみられたが, PCでは同所見は認められ なかった. 4.CT：TFP8 例中 7 例は iso density であったが, PCでは 15 例中 14 例は low density で iso density は 1 例のみであった. 5. ERCP : 胆管と苏管の造影が可能であった TFP7 例と PC 12 例の検討では, PC

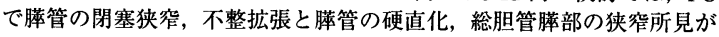
高率に認められた. 6 . 血管造影：両者に有意差のある所見は認められな かった.【まとめ】USにおける duct penetration sign や ductal structure, CTにおける iso density, ERCPにおける smoothな狭窄所見などが TFP と PC の画像所見における鑑別点として重要であるが, 正確な鑑別 はむずかしく今後も両疾患を念頭におき，診断・治療をすすめる必要が あるものと考えられた.
PS13-03腫瘤形成性䐙炎の臨床 - 各種画像診断の特徵と治療指針 相浦浩一", 高橋 伸"2, 上田政和", 島津元秀", 若林 剛", 田辺 稔"，北郷 実"，鈴木慶一", 星本相淳", 熊井浩一郎", 北島政樹” (慶應義塾大学外科"，日本鋼管病院外科”）

【目的】腫瘤形成性膵炎の臨床および各種画像診断における特徵と治療 指針について検討した.【方法】’ 90 年から’ 00 年までに当科で扱った腫 痹形成性腪炎 9 例を対象とし, 臨床, 各種画像について再評価した. (成 績】平均年齢は 56 歳, 全例男性であり, 病変部はいずれも荤頭部であっ た. US では, 腫瘤の辺縁, 境界, 内部構造に特有な所見は必ずしも指摘 できず，血管造影でも捇動脈アーケードの屈曲・蛇行を $44 \%(4 / 9)$ に, 閉塞を 1 例に認め, 膵癌との鑑別は困難と思われた。これに反して, 胆 管・䐙管造影では完全閉塞を示した症例はなく, 胆管造影にて狭窄を示 した症例は 78\%（7/9）でいずれも平滑であり，膵管造影でも $75 \%(6$ /8) が主膵管の狭窄像を呈し, 1 例を除き平滑でかつ狭窄部からの分枝滕 管が造影されていた. CT dynamic study では早期動脈相で周囲膵実質 と同等に濃染される症例が $67 \%$ (4/6) あり，2 例は低濃度を示したが， この 2 例は胆管・捇管造影の平滑な狭窄像, または慢性腪炎特有の主捇 管の数珠状拡張を示した. US. CT にて体尾部の腫大を示したものは 9 例中 5 例で, それらの成因はいずれも突発性で, 腫大を伴わなかった症 例はいずれもアルコール性であった. 病理組織学的にも体尾部の腫大を 伴った症例はいずれも高度の炎症性細胞浸潤を伴っていた．今回検討し た 9 例中 7 例に腪頭十二指腸切除術, 1 例に䐙全摘を施行したが, 腫瘤形 成性䐙炎を疑った黄疸発症例 1 例に対しては, チューブステントを挿入 し約 4 年間経過観察した．その後ステントを抜去したが, 胆管は開存し ており, 現在ステントの再捜入なく経過良好である.【結論】以上より, US・血管造影の所見からは腫嘴形成性滕炎と蓃癌の鑑別診断は困難と 考えられたが, 成因, 腪腫大の有無, 詳細な胆管・胼管造影所見および CT dynamic study による腫瘤の血流評価の組み合わせにより，かなり 鑑別が可能になるのではないかと考えられた．また，腫瘤形成性䐙炎を 強く疑うことができれば, 黄疸例ではチューブステントなどの保存的治 療も可能と考えられた。
PS13-04腫瘤形成性荤炎の診断一CEUS と PTP およびSPVによ る膵癌との鑑別診断一

木下壽文, 永嶋 潤, 八次浩幸, 西村一宣, 児玉孝仁, 川畑方博, 橋本 光生, 橋野耕太郎, 玉榮 剛, 原 雅雄, 江里口直文, 青柳成明 (久留米大学外科学)

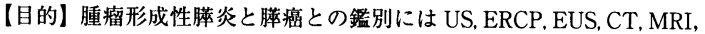
血管造影などの画像診断の発達した現在でも診断に苦慮する症例に遭 遇することがある．今回は腫嘴形成性膵炎の診断，特に膵癌の鑑別診断 として CEUS と PTP およびSPV の有用性について検討した.【対象】

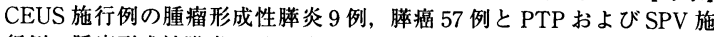
行例の腫瘤形成性腷炎 32 例, 羘癌 109 例を対象とした. CEUSにおける 造影効果の判定はエコーレベルの違いにより，まったく enhance されな い群を hypoA, 若干 enhance される群を hypoB, 膵実質と同様に enhance される群を iso, 䐙実質以上に enhance される群を hyperに分類, PTPにおける門脈像は正常型を I 型，圧排型を II 型，狭空型を III 型， 閉塞型を IV 型に分類し検討した. SPVによる䐙静脈像を偏位, 狭窄, 閉 塞, 血管增生, 血管拡張, 側副路形成の 6 項目について検討した.【結果】 1.CEUS：腫瘤形成性膵炎 9 例では hypoA；1 例, iso ; 8 例で hypoB, hyperはみられず, iso が 9 例中 8 例, $88.9 \%$ であった. 捇癌 57 例では hypoA；26 例, hypoB；24 例, iso; 5 例, hyper ; 2 例 で, hypoA, B が 57 例中 50 例, $87.7 \%$ を占めていた. 2. PTPによる門脈像：腫瘤形成 性䐙炎 32 例では I 型； 17 例, II 型； 7 例, III 型； 4 例, IV 型 ; 4 例で, I 型は $53.1 \%$ で III 型以上の高度所見例は $25.0 \%$ であった。荤癌 109 例 では I 型；22 例, II 型； 6 例, III 型； 41 例, IV 型；20 例で, I 型は 20.0 \%で III 型以上は $56.0 \%$ であった. II 型は腫瘤形成性茦炎 $21.9 \%$. 䐙癌

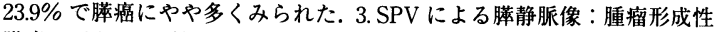
䐙炎 32 例では血管增生 $78.1 \%$, 血管拡張 $68.8 \%$ が主所見で狭窄 (滑らか な狭小化）は $31.3 \%$ にみられたが閉塞は $3.1 \%$ と稀であった．腪癌 109 例では䐙静脈枝の閉塞 $88.3 \%$, 狭窄 (不整狭窄) $78.9 \%$ が主所見で側副 路形成 $21.1 \%$, 偏位 $19.3 \%$ で血管増生と血管拡張は少なく無血管野とし て描出されるのが特徴であった.【まとめ】 CEUSと PTPおよびSPV は 腫瘤形成性䐙炎の診断, 特に粗癌との鑑別には有用と思われた。 
PS13-05腫瘤形成性慢性腪炎の診断における炭酸ガスアンギオ下 US ·膵細静脈造影の有用性

水野修吾, 岩田 真, 田端正己, 山際健太郎, 伊佐地秀司, 横井一, 川原田嘉文

(三重大学第一外科)

【目的】画像診断の発達した現在においても, 櫒癌と鑑別が困難な慢性䐙 炎症例は少なくなく, 両者の治療方針は大きく異なるため,より正確な 鑑別診断を行うことは重要である. 今回, 腫瘤形成性慢性䐙炎を中心と した膵疾患の鑑別診断における炭酸ガスアンギオ下 US・膵細静脈造影 の有用性につき検討を行った. 【方法】1994 年 7 月以降, 当科で経験した 浸潤性膡管癌 46 例, 慢性膵炎 13 例のうち, 術前のUS, CT, 腹部血管造 影にて診断に難渋した膵疾患 12 例を対象. (最終診断では 6 例は膵管 癌, 4 例は腫瘤形成性慢性膵炎であり, 残り 2 例は経過観察・ステロイド 投与にて軽快した自己免疫関連蓃炎であった.)【結果】(1) 炭酸ガスアン ギオ下 US $(n=12)$ : 膵癌 6 例中 5 例は炭酸ガス注入後も hypo echoic であり, 1 例のみが iso echoic であった. 慢性满炎 6 例では 5 例が病変部

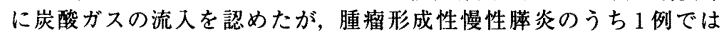
hypo echoic に描出された. (2) 䐙細静脈造影 $(\mathrm{n}=5)$ ：膵癌症例の 2 例は venous obstruction を認め, 慢性满炎症例の 3 例は obstruction を認めな かった. (3) 画像診断：膵癌 6 例中 6 例とも滕癌と診断したが, 慢性捇炎 6 例中腫瘤形成性慢性豚炎のうち 1 例を满癌と診断していた. (4) 治療： 膵癌 6 例中 PPPD 1 例, PD 2 例, 3 例にバイパス手術を行った. 腫 瘤形成性慢性膵炎 4 例では PPPD2 例, PD1 例施行し, 炎症が強度であっ た 1 例はバイパス手術を行った. また, 自己免疫関連滕炎 2 例は, 手術 を行うことなく経過観察・ステロイド投与にて自己抗体は陰性化し, 症 状も軽快した.【まとめ】診断困難な捇病変に対し, 炭酸ガスアンギオ下 US ・捇細静脈造影は有用であり, 愺癌と腫瘤形成性慢性腪炎の術前鑑別 診断のみならず, 手術を必要としない自己免疫関連䐙炎の診断にも有用 であった.

PS13-06 腫瘤形成性捇炎と满癌との鑑別とその治療 村上義昭", 横山雄二郎", 金廣哲也", 上村健一郎", 佐々木秀", 森藤 雅彦"，末田泰二郎"，檜山英三 ${ }^{21}$, 横山 隆 ${ }^{21}$

(広島大学第 1 外科", 広島大学附属病院総合診療部 ${ }^{21}$ )

(目的)腫瘤形成性膵炎は, 腫嘴の存在, 胆管, 膡管の狭窄 ·閉塞の併発 などにより，画像診断が発達した現在においても䐙癌との鑑別が未だに 困難な疾患であるが, 予後の悪い膵癌に対しては早期の愺切除を含む手 術が必要であり, 良性疾患である腫瘤形成性喏炎に対しては機能温存を 考虑した手術が重要であることなどを考えるとその鑑別は手術術式を 選択する上でも重要である. 今回, 腫瘤形成性䐙炎と䐙癌との鑑別とそ の治療について検討を行ったので報告する. (方法) 最近 12 年間に当科 で経験した術前膵癌を疑われて手術を施行した腫瘤形成性䕰炎 10 例 (男 10 例, 平均年齢 58 歳, $\mathrm{CP}$ 群) と腫瘤形成性茦炎と診断され手術を 施行した羘癌症例 2 例 (男 2 例, 平均年齢 44 歳, PC 群)を対象とした. これらの症例に対し, 術前の画像診断, 手術術式, 一部の症例に対して は術前採取した純粋满液によるテロメラーゼ活性について検討を行っ た. (結果) アルコール飲酒歴, 䐙石の合併は, それぞれCP 群で $8 / 10$, 4/10, PC 群で $1 / 2,0 / 2$ に認められた. 腫嘴の部位(頭部：体尾部), 平均 腫㣀径は, それぞれ, CP 群で $8: 2,35 \mathrm{~mm}, \mathrm{PC}$ 群で, $2: 0,30 \mathrm{~mm}$ であっ た. また, 羘管の狭窄拡張, 胆管の狭窄閉塞は, それぞれ, CP 群で $9 / 10$, 5/10, PC 群で 0/2, 2/2 に認められた. 純粋膵液の術前細胞診では, CP 群で $3 / 7, \mathrm{PC}$ 群で $0 / 2$ に悪性と診断され, テロメラーゼ活性は CP 群で 0 $/ 2, \mathrm{PC}$ 群で $1 / 1$ 陽性であった。画像診断で腫瘤形成性膵炎と診断され, 術前テロメラーゼ活性陽性の 1 例は腪頭十二指腸切除後に滕癌と判明 し, 手術術式の選択にテロメラーゼ活性測定が有用であった。手術は CP 群では, 捇頭十二指腸切除 3 例, 膵尾部切除 2 例, 滕管空腸側側吻合 2 例, Frey 手術 2 例, その他 1 例, PC 群では, 䐙頭十二指腸切除 1 例, 膵管空腸吻合 1 例が施行されていた. (結語) 腫嘴形成性滕炎と腪癌との 鑑別は, 術前画像診断などにては困難で, 術前の純粋膵液によるテロメ ラーゼ活性の測定が有用であった．また，膵管拡張を伴う腫瘤形成性腪 炎に対しては, その機能温存の面より, Frey 手術が妥当と考えられた.
PS14-01 重症急性膵炎の初期治療と外科治療成績の相関について 西川淳介, 竹山宜典, 上田 隆, 安田武生, 黑田嘉和 (神戸大学第一外科)

【目的および方法】1990 年以降経験した, 厚生省判定基準による重症急性 膵炎 88 例を対象として，1990 年から 1995 年 6 月までの, fluid resuscitation, 腹膜灌流を治療の中心とした前期群 51 例と, それ以降の従来の 治療に加え selective digestive decontamination(SDD), 腪酵素阻害剤と 抗生剂の持続動注, 臓器障害に対する持続血液滤過透析 (CHDF) を導 入した後期群 37 例の二群に分け，治療方針の変遷による手術を含めた 治療成績を比較解析した。手術適応は，前期後期ともに腹腔内または， 後腹膜に感染がある, または疑われるものとした.【結果】重症度および 急性䐙炎の成因, 年齢, 性差には前期と後期で有意差はなかった，臓器 障害合併率は前期 $54.9 \%$, 後期 $56.7 \%$, 壊死性滕炎合併率も前期 $58.8 \%$, 後期 $59.4 \%$ で差は認めないが, 治療中の感染性膵壊死合併率は前期 29.4 \%に対して後期 $18.9 \%$ と減少した，手術施行率（胆道系手術を除く）も 前期 $43.1 \%$ に対して後期 $18.9 \%$ と減少した. 発症から手術までの日数 は, 前期で 29.2 日に対して後期 28.5 日と差は認められなかった. 全体の 死亡率は, 前期 $37.3 \%$ に対して後期 $20.0 \%$ と隇少しており, 壊死性䓦炎 に限定した死亡率も前期 $56.7 \%$ に対して後期 $36.4 \%$ と改善傾向が見ら れた. しかし手術施行例における死亡率は前期 $66.6 \%$, 後期 $62.5 \%$ と大 きな変化を認めなかった.【まとめ】初期治療において fluid resuscitation, 腹膜灌流に加え持続動注療法や SDD, CHDF などの新しい治療戦 略の導入により, 重症急性膵炎における感染性合併症と予後の改善が見 られたが, 手術成績の改善には, 低侵襲手術などのさらなる工夫が必要 と考えられた.

\section{PS14-02 重症急性䐙炎の治療戦略〜集中治療の有効性と手術適応} の再検討

森口武史, 平澤博之, 織田成人, 志賀英敏, 中西加寿也, 北村伸哉, 松 田兼一, 上野博一

(千葉大学救急部 ·集中治療部)

【目的】重症急性膵炎 (SAP) に対する集中治療の有効性と手術適応につ き再検討する事を目的とした。

【方法】過去 10 年間の SAP37 症例について, SAP と診断されてから 3 日以内に SIRS 対策として CHDF (continuous hemodiafiltration)を開始 した CHDF 早期施行群とそれ以降に開始した CHDF 非早期施行群, BT (bacterial translocation) 対策として SDD (selective digestive decontamination)を施行したSDD 施行群と施行しなかった非施行群にそれぞ れ分類し, 予後, 感染性䐙合併症の有無, 施行した手術とその時期につ いて検討した。

【結果】症例の平均年齢は 50 葴, 29 例は男性であり, 37 例中 33 例 89 \%を救命した. CHDF 早期施行群は 31 例中 29 例 $94 \%$ を救命したが, $\mathrm{CHDF}$ 非早期施行群は 6 例中 4 例 $66 \%$ を救命するにとどまった. SDD 施行群 28 例中 26 例 $93 \%$ を救命し, 感染を認めたのは 4 例 $14 \%$ であっ た.SDD 非施行群は 9 例中 7 例 78\% を救命するにとどまり 5 例 $56 \%$ に 感染性膆合併症が発症し，4例に open peritoneal drainage を施行した. またSDD とCHDF が適切に施行された 25 例においては, 24 例 $96 \%$ を 救命し, 発症早期の手術施行例は仮性芽襄胞に対する経皮的 drainage 術を施行した 2 例のみであった。

【まとめ】本来無菌的炎症であるはずのSAPに対する手術適応は，発症 早期の BTによると考えられる感染性蓃合併症に対する場合と，晚期の

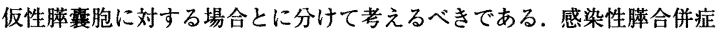
の診断がついた場合には時期を逸することなく手術を施行するべきで あるが, SDD と CHDFを適切に施行すれば手術適応に至る症例は少数 であり, SIRS 対策としての CHDF および BT 対策としての SDD を中心 とした集中治療こそSAPの治療において重要であると思われる。 
PS14-03 重症急性脇炎に対する治療法の選択 大梘穣治"，中村正彦"，長尾 建"，丹正勝久"，矢崎誠治", 林 成 之", 宋 圭男 ${ }^{21}$, 山形基夫 ${ }^{21}$, 村山 公2), 佐藤博信"2, 岩井重富 ${ }^{21}$ (日本大学救急医学"，日本大学第三外科 ${ }^{21}$ )

【はじめに】重症急性䐙炎は, 依然として予後不良の疾患であるが, その 死亡率は，様々な新しい治療法や厳密な患者管理により改善されてい る. 当院でも 1995 年以降, 重症例に対してはスワンガンツカテーテルに よる循環管理を全例に行い, 手術以外に水分, 電解質管理, 各種メディ エーター除去目的の持続血液滤過透析 (CHDF), 满醭素阻害片及び抗生 剤の動注療法、腹膜潅流などの集学的治療法を施行している。そこで今 回我々は当院における重症急性滕炎の治療経験について検討したので 若干の文献的考察を加え報告する.【対象】 1992 年から 2001 年 2 月まで に当院で経験した 36 例の重症膵炎患者を対象とした. 男女比は $28: 8$, 平均年齢は 48.0 歳 (26 歳〜 76 歳)であった. 成因は重複を含め, アルコー 儿性 27 例, 胆石性 5 例, 特発性 3 例, その他高脂血症, 副甲状腺機能立 進症，総胆管腫瘍などによるものであり，入院時の CT grade は grade $3=9$ 例, grade $4=21$ 例, grade $5=6$ 例であった. 【治療法】 4 例に対して

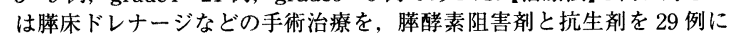
対しては動注にて, 3 例に対しては経静脈的に投与した.これらのうち, 2 例に対しては腹膜潅流を, 21 例に対してはベンチレーターによる呼吸 管理を, 15 例に対してはCHDF を施行し，保存治療を選択した症例のう ち 2 例は感染からドレナージを要した.【転帰】当初より手術治療を施行 した 4 例は全例軽快したが, 2 例に癒着性の腸閉塞や消化管穿孔を合併, 当初動注療法などの保存治療を施行した 32 例中 28 例は軽快したが, 1 例が重篤な合併症をのこし, 3 例が死亡（2 例が MOF，敗血症， 1 例が 悪性腫瘍による原病死）した.【考察】集学的治療の結果, 当院で経験し た重症急性腪炎 36 例中 32 例 (88.9\%) が軽快した. 動注療法をはじめと する集学的治療は発症早期の SIRS による多葴器不全に対し有効な治療 法であると思われたが, 救命率向上のためには感染合併症例に対する手 術のタイミングが重要であると思われた。

PS14-04 重症急性腪炎における手術適応とその時期の検討 古屋智规" , 安藤秀明"', 吉岡政人 ${ }^{21}$, 小山研二"2!

(市立秋田総合病院 ${ }^{1)}$, 秋田大学第 1 外科 ${ }^{21}$ )

【目的】重症急性膆炎の手術適応は続発性感染併発時とされるが, 感染の 診断は困難で, 手術適応と時期を決定することは容易でない. また, 保 存的治療に限界のある症例も経験する. そこで当科での経験した症例を retrospective に検討し,これらを決定し得る指標およびその問題点を明 らかにする.【方法】' 92 -'00 年の重症急性腪炎 28 例を対象とし, 以下の項 目を検討した. 1. 手術例 13 例の転帚と腪炎発症〜SIRS 指標再増悪日 (臨床的に感染が疑われる日) 〜手術日の期間. 2. 術前 IL6 值と感染有 無. 3. 腪酵素阻害剂・抗生剤持続動注療法 (CRAI), selective digestivedecontamination (SDD) + 経腸栄養と感染例との関連. 感染有無は壊 死物質などの培盖より確定した. 4.エンドトキシン吸着療法 (PMX) の 有効性を検討. 5 . 死亡例（手術例 5 例非手術例 2 例）の死因から手術適 応の有無, 時期の適否, 術式について検討.【結果】1.腪炎発症〜SIRS 指標再増悪日の期間は生存例 10 150日 (中央值 47 日 ; 以下同) 死亡例 14〜38 日（17日）で死亡例で短かった. SIRS 指標再増悪日〜手術日, 荤炎発症〜手術日は生存例と死亡例間に差を認めなかった．2.術前 IL6 值は感染例では $535.5 \pm 108.5 \mathrm{pg} / \mathrm{ml}(\mathrm{N}=3)$ で, 培養陰性例 $53.6 \pm 63.5 \mathrm{pg}$ $/ \mathrm{ml}(\mathrm{N}=3)$ に対し高值だった. 3.7 日以内に抗生剤併用 CRAI 開始し た 14 例, SDD + 経腸栄盖 4 例に感染例を認めなかった. 4.PMX5 例中 3 例で血圧上昇などの効果あり 1 例を救命した. 5 . 手術死亡例の死因は肺 塞栓 2 例 (うち 1 例は培養陰性), 出血 2 例, 敗血症 1 例で凝固異常に伴 う死因が主であった。非手術死亡 2 例は膵炎発症早期に広範な門脈血栓 を合併, 剖検で脾静脈より進展したと考えられた.【まとめ】1. 早期 SIRS 指標再増悪例は予後不良で㠜固異常に伴う死因が多いことから, 手術適 応は慎重に判断し, 凝固異常の対策や PMX 使用を考虑の上, 手術を施行 する. 2. 術前 IL6 值は手術適応の有用な指標となり得る. 3. CRAI, SDD 十経腸栄養は感染を減少させる. 4. 発症早期に脾静脈血栓を合併する症 例では早期に門脈ステント留置等で救命の可能性がある.
PS14-05 壊死性膵炎における RNL（retroperitoneoscopy-assisted necrosectomy and closed lavage) の適応

佐々木誠, 古川正人, 德永祐二

(国立長崎中央病院外科)

壊死性喏炎に対して, 動注療法と CHDF, 呼吸管理の組み合わせが, 早 期治療の中心として認知されている.しかし，広範な後腹膜壊死に起因 する大腸を中心とした腸管の壊死, 虚血病変が, bacterial translocation や感染に密接に関連していることに注目する必要が出てきた，RNL (retroperitoneoscopy-assisted necrosectomy and closed lavage)は, その 後腹膜壊死そのものを, 低侵襲に除去する試みである.【背景】 1994 年 1 月 2000 年 12 月に重症苹炎 14 例 (男：女 $=13: 1$, 平均 44.4 藏) を 経験した. 初期の 7 例では, 動注療法 4 例, CHDF3 例を併施したが, 腸 管填死と虚血性腸炎によるエンドトキシンショックの 2 例が死亡した. また, 後腹膜壊死の消失まで, 保存的に 2 年を要した症例も経験した. 【対象と方法】その後の 7 例では, 動注療法 6 例, CHDF4 例を施行し たうえ, 約 2 週間の時期に, CTgradeIV 以上の広範な後腹膜壊死がみら れ, 白血球数, CRP が高值を持続する 4 症例に RNL を併施した. RNL： 側腹から, 後腹膜に入り, 開創器で腹腔内臟器を腹側に持ち上げ腔を保 つ. 鏡視下に, 腹腔鏡用具の鉬子, 剥離子を用いて necrosectomyを行っ た後, 菜体部背側を通り大動脈周囲に後腹膜洗浄用チューブを留置す る. 術後から, 生食水 $1 \mathrm{~L}$ を 1 日 2 回, 低圧持続吸引で灌流する.【成績】 RNL 施行 4 例の平均手術時間は, 116 分, 平均術中出血量は, $231 \mathrm{gr}$ であ り, 壊死巣の感染は認めなかった。 4 例中 1 例は, 主要血管に異常所見が あり, 入院時からの循環不全, ショックから回復せず, 12 日目に死亡し た. しかし, 残りの 3 例では, RNL 後, 急速に重症度スコアが改善した. 更に, 持続後腹膜洗浄を始めて約 1 週間目には, 腸管運動が回復し, 排 ガス, 排便が認められ, 腸管合併症の防止効果を示した.【結語】集中 治療後 2 週間の時期に, CT 上, 広範な後腹膜壊死があり, 白血球数, CRP が高值を持続する症例では, 感染が特定されない場合でも, 腸管合併症 を防止する意味合いから，RNLが有効と思われる. しかし，初期集中治 療無効の最重症型には, 今のところ有力な手段はない.

\section{PS14-06} 単球・好中球の表面抗原からみた重症䐙炎の感染予知と

手術適応

相原 司, 初瀬一夫, 川原林伸昭, 渡邉覚文, 大㴊康弘, 辻本広紀, 松 本 淳, 滝川利通, 上田重人, 小野 聡, 望月英隆

(防衛医科大学校第 1 外科)

【目的】重症荤炎では, 感染がその予後に大きく影響するが, 感染の診断 ならびに手術適応に関しては未だ controversial である. 今回, 生体侵襲 の指標とされる単球・好中球の表面抗原の推移が, 重症荤炎の感染予 知, 手術適応に有用であるか検討した.【対象と方法】入院時ならびに経 時的に単球・好中球表面抗原を湘定しえた重症膵炎 6 例を対象とした. flowcytometry を用い, 感染予知の指標として lipopolysaccharide (LPS) + LPS 結合蛋白受容体である単球 CD14, 生体侵襲の指標として単球・ 好中球の CD11b の発現強度を測定した. 正常人の range から単球 CD14 の正常值を 1000 以上, 500-1000を低下, 500 未満を著明低下, 単球 CD $11 \mathrm{~b}$ の正常值を 90 未満とし, 90-200を上昇, 200 以上を著明上昇, 好中 球 CD11b は正常值を 60 未満, 60-120を上昇, 120 以上を著明上昇とし た.【結果】重症度は stage $2 ; 1$ 例, stage $3 ; 3$ 例, stage $4 ; 2$ 例であった. 単球 CD 14 は, 入院時に正常が 2 例, 低下が 2 例, 著明低下が 2 例であっ た. 単球 CD14 が入院時正常範囲でその後も正常範囲で推移した 2 例及 び, 入院時低下していたが, その後も変化が少なかった 1 例は感染非合 併で経過した。一方，入院時低下していた単球 CD14 が経過中に著明低 下に移行し，好中球 CD 11 b が著明上昇した 1 例は入院後 9 日目に手術 を施行したが, 感染性腪壊死症例（グラム陰性桿菌陽性）であった. 入 院時, 単球 CD14 が著明低下の 2 例では, 単球 CD11b, 好中球 CD11b は正常ないし軽度上昇で, 感染はあるものの生体への影響は少ないもの と考え, エンドトキシン吸着 (PMX) を施行した。 1 例はCD14 が増加 せず, その後膡膿瘍となりドレナージを必要とし, 他の 1 例は次第に CD 14 は正常化し, 外科的処置の必要なく退院となった.【結語】重症朠炎で 単球 CD14 の経過中著明低下, 単球 CD11b, 好中球 CD11b の著明上䄯の 場合, 外科的処置を要する感染合併であり, 短時間で測定可能なこれら の表面抗原の動態は感染予知, 手術適応の指標となりうることが示唆さ れた. 
PS15-01 小腸機械的イレウスの手術決定の目安と術式 渋谷 寛, 田畑峯雄, 渾内十郎, 大迫政彦, 黑木直哉, 久米村秀, 末永 光邦，亀川宽大，迫田晃子，迫田晃郎

(鹿児島市医師会病院外科)

小腸機械的イレウスの手術決定の目安と術式【目的と対象】1998 年 1 月から 2000 年 12 月までの小腸機械的イレウス 153 例（平均年齢 65.2 歳, 男女比 88：65)のうち絶食のみで改善した 44 例を除く 109 例を対象 とした.これらを緊急手術群 (A 群 : 36 例), 隇圧後手術群 (B 群 : 20 例), 保存的治療群 (C 群：53 例) の 3 群に分類し手術決定の目安と術式 について retorospectiveに検討した.【結果】A 群の術前診断は絞扼 25 例, SMA 血栓症 2 例, 閉鎖孔ヘルニア 3 例, 隇圧チューブ挿入不可 5 例, 消化管穿孔 1 例であった. 術式は腸切除 13 例, 絞扼解除 6 例, 内へ ルニア根治 3 例, 異物排出 2 例, 癒着剥離 11 例, 試験開腹 1 例を行った。 絞扼を疑った 23 例のうち 7 例は癒着性イレゥス, 2 例は食䬣性イレウ ス，1例は虚血性腸炎であったＢ群は隇圧チューブを留置したが, 保存 的治療の限界と判断し手術を行った. 内訳は減圧効果不良 12 例, 絞扼疑 い 5 例, 造影による高度狭窄 3 例であった. 7 例は絞扼性イレウスであっ た. 11 例に瘉着剥離, 3 例に絞扼解除を行ったが, 6 例で腸切除（絞扼 4 例，狭窄 2 例）を必要とした，B 群の平均隇圧期間は 2.7 日で平均排液 量は $831 \mathrm{ml} /$ 日, C 群の平均隇圧期間は 5.4 日で経口開始まで平均 6.8 日, 平均排液量は $444 \mathrm{ml}$ /日であった。 WBC, CRP は A 群がC 群に対し有意 に上昇していたが AMY,LDH，CPK に有意差はなかったままたSIRSの 有無には有意差はなかったが，筋性防御の有無に 3 群間で有意差を認め た.【結語】イレウス治療にあたっては絞扼性イレウスを早期診断する事 と保存的治療の限界を見極める事が重要である. 当院では緊急手術の適 応には疼痛の程度と理学所見を最優先し, 画像診断と血液検査結果を参 考に決定している．保存的治療を選択した場合は経時的に腹水・疼痛・ 炎症所見の変動を観察し手術時期を逸することがないように留意して いる，また症状に変化が無くとも減圧チューブ留置期間は 5 日をめどに 手術を検討している．画像診断の向上により絞扼性イレウスの診断能は 上昇したが，各種所見に単独では有用な evidence はないため総合的に 判断し適切な時期に手術に踏み切ることが重要と考える。

PS15-02絞抳性イレウスの手術決定因子

㴊上ひろみ, 川元俊二, 古藤 剛, 㴊野泰秀, 稲田一雄, 井上徹, 藤 川幸一

(福岡德洲会病院)

絞抳性イレウスの手術決定因子㴊上ひろみ，川元俊二，古藤 剛，㴊野 泰秀, 稲田一雄, 井上 徹, 藤川幸一福岡徳洲会病院外科【目的】緊急 手術が必要な絞扼性イレウスに対し迅速で適切な治療方針を決定する 手だてとなる因子について検討した.【方法】1997年 1 月から 2001 年 1 月までの 4 年間に手術をおこなった絞㧪性イレウス（S 群）46 例（腸管 非壊死群 : SV 群 23 例, 腸管壊死群 : SN 群 23 例) と単純閉塞性イレウ ス (O 群) 36 例を対象とした. 手術決定の因子として各群に特街的な $\mathrm{CT}$ 所見および臨床検查所見, さらに臨床経過における各所見の発現の特徵 について比較検討した ( $\lambda 2$ 検定).【結果】S 群に特徵的な CT 所見は, (1) 腸間膜収束 (2) 腹水貯留 (3) closed loop sign（4）腸間膜の血管怒脹 （5）腸管壁の造影不良（6）壁内ガスであり，このうち (4) (5) (6) の 3 所見が SN 群に有意多くみられた. 臨床検査所見では (A) CPK >200IU /1（B）腹水穿刺での血性腹水（C）ショック症状（D）代謝性アシドー シス（E）腹膜刺激症状が $\mathrm{S}$ 群に有意に認められ，このうち (D) (E) が SN 群に多かった，発症から手術に至った経過時間は，O群で $21.8 \pm$ 158.98 時間, SV 群で $75.1 \pm 84.04$ 時間, SN 群で $50.7 \pm 80.47$ 時間で, O 群で有意に長かった. 手術決定の最終判断理由は, SV 群では絞扼性イレ ウスと術前彭断された $(63.6 \%) 14$ 例のうち，8例がCT 所見のみ， 2 例が CT 所見と CPK 高优, 2 例が腹水穿刺で診断したが, 確定診断が得 られず試験開腹した症例が 9 例あった. SN 群では術前診断し得た $(78.3$ \%) 18 例のうち, 8 例が CT 所見のみで診断し，他の 10 例は CT 所見と 供に他の臨床所見が手術の決定要因として加わり判断が容易であった. 発症からの時間経過と各所見発現の関係では SN 群では早期より CT, 臨床検查所見が併存発現したのに対し,SV 群で血液検查所見が発現し ていない早期から，特徴的な CT 所見を認めており，腸管壊死回避のた めの手術決定にCT 所見はに有用であった.【まとめ】腸管壊死の回避 と，壊死を伴う場合の救命のための緊急手術の決定要因に今回判明し得 た特徴的臨床所見とともに特にCT 所見が有用であった。
PS15-03画像所見よりみたイレウスの手術決定の目安一絞扼性と 単純性イレゥスの比較から-

入野田崇"，大森浩明"，川崎雄一郎"，板橋哲也"，旭 博史 ${ }^{2 !} ，$ 斎藤和 好

(岩手医科大学高次救急センター" , 岩手医科大学第一外科" ${ }^{21}$ )

【目的】絞扼性イレウスに対する術前診断は画像診断の進歩に伴い向上 している. 今回我々は, 絞扼性イレウスと単純性イレウスを比較しその CTおよびUSの特徴的な画像所見を検討した. 【方法】1995.1 2001.1 まで当施設で経験したイレウス症例 186 例のうち, 外ヘルニア等を除く 小腸閉塞 96 例を対象とし, US および CT 検査所見を比較した. 2 群間の 差の検定は, Mann-WhitneyのU 検定を用いた.【結果】性別は男 55 例, 女 41 例で, 年齢は 18 96 歳 (平均 60.6 歳) であった. 内訳は絞扼群 26 例, 単純群 70 例で，原因は癒着が多く絞扼群は $20 / 26$ 例 $(77 \%)$ ，単純 群は $61 / 70$ 例 $(87 \%)$ であった. また, 絞扼群では虫垂切除, 婦人科手 術などの下腹部の疾患が多い傾向にあった．治療は絞㧪群では全例手術 を施行し， 21 例 $(81 \%)$ で腸管切除を行った。また単純群は 59 例 $(84$ \%) が保存的に改善し，11 例で手術を行った．転帰は絞扼群の 2 例が死 亡した. 画像所見を比較すると, US 所見では腹水眝留例は絞扼群 $25 / 26$ 例 $(96 \%)$ で単純群 $32 / 70$ 例（46\%）と絞扼群で有意に多く，また腹水 量を推定すると絞扼群 $426.9 \pm 285 \mathrm{ml}$, 単純群 $130 \pm 175 \mathrm{ml}$ と有意に絞扼 群の腹水量が多った．腸蠕動の停止，微弱例は絞扼群 17/26 例 (65\%) て 単純群 $16 / 70$ 例 $(22 \%)$ と絞扼群で有意に多く, 逆に立進例は絞扼群 2 $/ 26$ 例 $(77 \%)$ と単純群 $40 / 70$ 例 $(57 \%)$ で単純群に多った，次にCT 所見では腸管壁を測定し壁が $5 \mathrm{~mm}$ 以上の肥厚例は有意に絞抳群で多 かった．壁内ガスは絞扼群 $4 / 26$ 例 (15\%) に認めた。 18 例に腹水穿刺を 行い $\mathrm{Hb}$ が $0.1 \mathrm{mg} / \mathrm{dl}$ 以上検出された例は絞扼群 $11 / 12(92 \%)$, 単純群 1 /6 (17\%) と有意に絞扼群で多かった.【まとめ】USでは腹水量の多塞, 腸管蠕動の停止, CT では $5 \mathrm{~mm}$ 以上の壁の肥厚が絞扼性イレウスで有 意に高率に認められ，さらに腹水穿刺液中の $\mathrm{Hb}$ (血性腹水) を測定する ことでより高い正診率が得られると考えられた。

PS15-04 APACHE2,3,SOFA score からみた,イレウスにおける手 術時期決定の目安の検討

皆川輝彦，加瀬 肇，餵澤尚宏，戸倉夏木，本田亮一，栗原聰元，寺本 龍生, 小林一雄, 平野敬八郎

(東邦大学第 1 外科)

【目的】APACHE2,3,SOFA score を用いイレウス患者の手術時期を検討 した.【方法】当科に扔ける 1996 年より 2000 年に扔ける 5 年間で，検索 し得たイレウス患者 57 例を対象とし APACHE2, 3,SOFA score を求め た【結果】検索し得たイレウス患者のうち，癌性イレウスを除き手術施 行例は 17 例 (絞扼性イレウス 13 例, 癒着製イレウス 4 例), 非手術施行 例は 16 例であった。手術例の score の平均（平均値士標準偏差）は APACHE2 $(6.7 \pm 4.2), 3(27.2 \pm 19.8)$, SOFA $(1.1 \pm 1.4)$ で, 非手術例 ではAPACHE2 $(4.4 \pm 2.5), 3(15.6 \pm 11.9), \operatorname{SOFA}(0.6 \pm 1.4)$ であった. 各 score についてそれぞれウエルチ検定を行ったが有意差は認められな かった.この原因として APACHE scoreではバイタルサイン, 検査所見 が良好でも特に高齢者で年齢による point の占める割合が大きいためと 考えられたため，年齢による point 除き同様に検定を行ったところ手 術例では非手術例に比べ有意に高値であった．また，手術例について生 存例 15 例, 死亡例 2 例について同様にそれぞれの score を求め検定をお こなったが有意差は認められなかった。ささらに手術例において腸切除施 行 6 例と非施行 11 例について各 score を用い検定を行ったところ非手 術例に比べ手術例で APACHE2 score が有意に高值で, 腸切除施行 6 例の内 4 例 $(67 \%)$ が 10 以上であった．非腸切除例では 11 例中 9 例 $(82 \%)$, 非手術例では 16 例全例が 9 以下であった.【総括】今回の検討で はSOFA からは手術時期決定の目安となる結果は得られなかった。 た, APACHE score では特に年齢による影響が大きいと考えられた. 腸 切除が必要とされた症例は非腸切除例に比べ APACHE2score が有意に 高く, score が 10 以上では $67 \%$ に腸切除施行されており，10 以上とな る症例では早期に手術を検討するべきであると考えられた。 
PS15-05

癒着性イレウスにおける保存的治療期間の限界と手術の

タイミング

島田長人, 石井 淳, 金子奉暁, 白倉立也, 越野秀行, 石井貴士, 若林 峰生, 村国 均, 北原信三, 柴 忠明

(東邦大学第二外科)

[目的]術後の癒着性イレゥスは, 現在では保存的的治療が第一選択であ る。過去の教室例における寛解率の推移をみると，1967一-1976 年では $46.2 \%$, 保存的治療が皘極的に行われるようになった 1977一-1990 年では $71.1 \%$ であり，最近の 1991 年以降では $75.9 \%$ が寛解している. しかし， その保存的治療期間の限界つまり手術治療に踏み切る夕イミングにつ いては現在のところ統一された基準はない. 手術適応とする参考所見と してイレウス管からの排液量の推移や選択的小腸造影検查の所見なと が重要となるが， かならずしも容易に判断できる症例ばかりではない. 保存的治療期間の限界とは判断に迷う症例であっても，ある一定期間が 過ぎれば寛解が期待できず手術治療が必要となる時期と考えられ重要 な指標のひとつと言える. そこで教室で経験した最近の瘾着性イレウス を対象としてその保存的治療期間の限界について検討した [方法] 1991 年以降, 教室で経験した単純性イレウスのうち精査にて明らかな癌性腹 膜炎や大腸癌イレウスなどを除き癒着性イレウスと診断された 133 例 について検討した. [結果] 133 例中, 保存的治療で寞解した症例は 101 例 $(75.9 \%)$, 手術治療に踏み切った症例は 32 例 $(24.1 \%)$ であった. 発 症時期別では術後早期（術後 2 週間以内に発症）は 29 例 $(21.8 \%)$, 術後 晚期（術後 15 日以降に発症）が 104 例 $(78.2 \%)$ で，そのうち寞解症例 は術後早期で $62.1 \%$ ，術後晚期で $79.8 \%$ であった．寛解症例における保 存的治療期間は術後早期では 3-15 日間 $(9.4 \pm 3.4$ 日間 $)$, 術後晚期では 1-14 日間 $(4.7 \pm 3.2$ 日間 $)$ であった. 保存的治療期間と寛解率の関係を みると, 5 日以内では早期例が $16.7 \%$, 晚期例が $67.5 \%, 7$ 日以内では早 期例が $22.2 \%$, 晚期例が $80.7 \%, 10$ 日以内では早期例が $55.6 \%$, 晚期例 が $91.6 \%$ で 14 日以内では両者ともにほほ 100\% が寛解していた. [まと め] 瘾着性イレウスの保存的治療期間の限界は, 術後早期発症例では 2 週間, 術後晚期発症例では 10 日間を目途として保存的治療を行ない, そ の後 2-3 日間で寛解しない場合は手術治療の適応と考えられた.

PS15-06 消化器癌の再発に伴う腸閉塞に対する外科治療 網倉克己, 小林照忠, 小林光伸, 尾形昌男, 右田隆之, 西村洋治, 坂本 裕彦, 内田健二, 田中洋一, 関根 毅

(埼玉県立がんセンター)

$<$ 目的>消化器癌の再発に伴う腸閉塞 33 症例に対する外科治療経過に ついて検討した. <方法>原疾患は胃癌 17 例, 結腸癌 6 例, 直腸癌 6 例, 膵体部癌 2 例, 十二指腸乳頭部癌 1 例, 胆裹癌 1 例であった. 消化 管バイパス術 14 例, 小腸あるいは結腸部分切除術 8 例, 人工肛門造設術 9 例, 試験開腹術 1 例, 胃瘦造設術 1 例を施行した. 27 例は癌性腹膜炎 による腸閉塞（腹水あり 10 例; $\mathrm{A}$ 群, 腹水なしあるいは少量のみ 17 例； B 群），6 例は局所再発 (切除不能; C 群)による腸閉塞のため開腹 術を行った. 腹水の有無, 再発形式による治療経過について検討した. <結果 >癌性腹膜炎による腸閉塞症例では, 腸閉塞発症から手術までの 期間は術前診断が癌性腹膜炎 (+) の症例で 13.8 日, 癌性腹膜炎 $(-)$ 症 例では 9.7 日と, 術前より癌性腹膜炎の診断がなされていた症例で手術 適応の決定に長い経過がかかった. A 群では直死 3 例 (30.0\%), $50 \%$ 生 存は 123 日, 経口攝取 1 か月未満 4 例, 平均経口攝取期間は 72 日であっ たのに対し, B 群では直死 1 例 $(5.9 \%), 50 \%$ 生存は 160 日, 経口掑取 1 か月未満 1 例, 平均経口攝取期間は 109 日であった. 生存期間に差は認 めないが $(\mathrm{p}=0.2933), \mathrm{B}$ 群で比較的長期の経口摄取が可能であった $(\mathrm{p}$ $=0.0715)$. 在宅療養可能となった症例は $\mathrm{A}$ 群で 3 例 $(30.0 \%)$ であるの に対し, B 群では 15 例 $(88.2 \%)$ と良好な結果が得られた。局所再発に よる腸閉塞症例 (C 群) では直死 1 例 $(16.7 \%), 50 \%$ 生存は 67 日, 経 口掑取 1 か月未満 2 例, 平均経口掑取期間は 42 日であり, B 群に比較し て短期の生存期間および経口摂取期間であった $(\mathrm{p}=0.0321)$. くまとめ $>$ 消化器癌の再発に伴う腸閉塞症例に対する外科治療は, 直死例も多く手 術適応決定には難渋する場合が少なくない. 全身状態に応じた外科治療 を行うことにより経口掑取再開による QOL 向上の可能性があるが, 腹 水が中等量以上あるいは局所高度浸潤症例では外科治療効果は少なく, かえって全身状態悪化を招く場合もあり，インフォームド・コンセント を十分に行うことが重要である.
PS16-01 関連 26 施設における綉径部ヘルニア手術法

蜂須賀丈博", 笠井保志"

(市立四日市病院外科"), 名古屋大学第二外科 ${ }^{21}$ )

目的) 90 年代に入り, 鼠径ヘルニア修復術は, 種々の tension fre repair の導入により，急速な変化を遂げた，今回われわれは，名古屋大学第二 外科関連 26 施設にアンケートを配布し, 現在採用している手術法を調 查し, さらに, 最も採用率の高かったメッシュプラグ法に関する検討を 行ったので報告する. 方法) 名古屋大学第二外科関連 26 施設に対し, 平 成 12 年 11 月以下のようなアンケート調查を行った. 1 . 直近 1 年間の成 人単径ヘルニア手術における, 手術法, 麻醉法, 入院期間について質問 した. 手術法は, 従来法 (Marcy, Bassini, IP repair, McVay, Shoudice, その他), 人工膜補強いわゆる tension-free repair として (Lichitenstein, mesh plug, PHS, Laparoscopic repair，その他）に分け回答を得た． 2. 最 も多く採用されている mesh plug 法について, 95 年以来の総手術数, 再 発数, onlay patchの固定, プラグの固定糸数について質問した. 結果) 1. 直近 1 年間の総手術総数は, 1648 例であった. 従来法と人工膜補強の 割合は，従来法 110 例 $(7 \%)$, 人工膜補強 $(93 \%)$ であった，従来法で は, IP repairが最も多かった。一方, 人工膜補強のうち, mesh plug 法は，26 全施設で採用されていた．PHS 法は，5施設が採用していた。 麻酔法は, 腰椎麻醉が 22 施設, 局所麻酔 11 施設, 硬膜外麻酔 5 施設で あった. 平均入院日数は人工膜補強で, 5.7 日であった. 2.95 年以来の mesh plug 法の総手術数は, 3941 例であった. 平均手術時間は, 36.7 分であった. 間接へルニアにおけるプラグの固定は, 3-4 針が多かった が, 固定しない施設が 1 施設あった. Onlay patch の固定は, 21 施設が 行っており，固定しないのは，4 施設のみであった，プラグの size は， 間接では L が，直接では EXが多かった，再発は，48例 $(1.2 \%)$ であっ た. プラグ感染を 9 例 $(0.2 \%)$ に認めた. 結論) 鼠径ヘルニア手術は, 人工膜を用いた tension free repair が大部分を占め, その多くは mesh plug 法で行われている. 再発率は, $1 \%$ 前後で, 術後愁訴も少なく, mesh plug 法は, 現時点での第一選択術式である.

PS16-02 鼠径ヘルニア根治術 Mesh Plug 法と PROLENE Hernia System 法の比較検討

後藤秀成, 柴田佳久, 千木良晴ひこ, 加藤岳人, 鈴木正臣, 松尾康治, 尾上重巳, 板津慶太, 会津恵司, 佐藤太一, 河原健夫

(豊橋市民病院一般外科)

【目的】鼠径ヘルニアに対する術式で再発率も低く優れた方法とされて いる Mesh Plug 法 (MP 法) と PROLENE Hernia System 法 (PHS 法) の比較検討.【方法】対象は当院における1996 年 1 月より MP 法で行っ た初発 561 症例と 1999 年 4 月より PHS 法で行った初発 29 症例. また 同期間における再発症例についても同様に検討した. 検討内容は両群間 の手術時間, 術後入院期間, 術後入院時経口鎮痛楽使用頻度, 合併症, 再発率等について行った【【結果】以下MP 法：PHS 法で述べる. 初発症 例では, 患者平均年齢 58.0 歳: 60.0 歳. 平均手術時間 59.8 分 : 64.5 分. 術後入院期間 1.17 日：1.63 日. 術後入院時経口鎮痛薬使用頻度 0.80 回： 0.87 回. 合併症 45 例 $(8.02 \%): 4$ 例 $(13.8 \%)$. 再発率 5 例 $(0.89 \%): 1$ 例 (3.45\%)．また合併症では皮下リンパ液貯瘤, 硬結が多いがこれによ る再手術はなかった. また再発鼠径へルニアに対し MP 法にて 31 症例, PHS 法にて 4 例に施行した. MP 法による再発 4 例に対して再度 MP 法を施行した. 再発手術症例は初発手術症例と比較すると, 患者平均年 龄が 68.0 歳と高く, また術後入院期間が 2.65 日と長かった. 再発手術症 例の合併症は 1 例のみで再々発は認めなかった.【総括】PHS 法の症例が まだ少なく症例数を重ねる必要があるが, 両群間に明らかな差を認める ものはなく, MP 法の再発率・合併症が低く有用な術式である事を示し た. また MP 法は再発症例にも有効であった，当院でのへルニア手術は 硬膜外麻酔で行っており最近では局所麻醉のみも取り入れ, 今後は両群 間ともに Day Surgery が可能と思われた. MP 法における再発防止の反 省点と今後の PHS 法の適応, 術式に関する今後の課題につき検討し報 告する. 
PS16-03 局所麻酔下 mesh plug 法による爯径ヘルニア根治術 伊神 剛, 長谷川洋, 小橧清二, 坂本英至, 柴原弘明, 太平周作, 森 俊治, 上原圭介, 服部弘太郎, 水野隆史, 杉本昌之

(名古屋第二赤十字病院外科)

（目的）当院では単径ヘルニアの標準術式として局所麻酔下 mesh plug 法による根治術を 1995 年 3 月から採用してきた. 本術式の有用性につ き検討する. (方法) 1995 年 3 月から 2000 年 12 月までに, 手術を施行し た 543 例を対象とし, 手術成績, アンケート調査を中心に臨床的に評価 し検討する. (結果) 1. 平均手術時間：62.6 分であった. 2. 局所麻酔量： 平均 $31.1 \mathrm{ml}$ であった. 3. 体動時痛 : $39.8 \%$ に認め, 期間は平均 6.2 力月 であった. 4.つっぱり感 : $44.7 \%$ に認め, 期間は平均 6.5 力月であった。 5. 満足度：満足 $54.4 \%$, やや満足 $15 \%$ と満足する例が多く, 不満 $1.3 \%$ と少なかった. 6. 再発例：鼠径へルニアとしての再発は，9例 $(1.66 \%)$ で, 内鼠径ヘルニアの形態で再発していた. 大腿ヘルニアとしての再発 が, 2 例 $(0.37 \%)$ であった. (まとめ) 1. 鼠径へルニアの術式として, 局 所麻酔下 mesh plug 法は, 標準術式と考えられる. 2. 最近の工夫として, 前投薬に midazolem を使用し, 術前の不安の除去する. 局所麻酔は手洗 い前に施行し, 時間を待つことにより, 十分な麻酔効果が得られる. へ ルニア囊は, 可能なら開放せず, ヘルニア門に plug を固定, onlay patch の先端を恥骨結節に確実に固定し，全周にわたり周囲組織と固定する.
PS16-05成人爯径ヘルニアに対して腹腔鏡下絾径ヘルニア修復術 はコンセンサスを得られるか？ 和田英俊, 川辺昭浩, 小林利彦, 礒垣 淳, 山下公裕, 佐藤正範, 数井 暉久

(浜松医科大学第 1 外科)

【目的】近年, 成人単径ヘルニアに対して tension-free の手術が増加して いるが, anterior approach の手術が主流で腹腔鏡下単径ヘルニア修復術 （以下 LH）を行なっている施設は少ない.この原因としては全身麻酔や 手術器械による経済性や手技の習熟度などが挙げられる。当科では良性 疾患であるへルニアにおいては美容的な創の大きさや手術の侵襲性を 追求するべきと考え，1992 年から基本的に全例に LH を施行しており， 更に 1996 年から $3 \mathrm{~mm}$ 径の細径器具を導入している. 今回, 成人単径へ ルニアに対してLHがコンセンサスを得られる手術であるかを検討し た【方法】1992年 8 月から 2000 年 12 月までに当科で施行した LH （TAPP 法）113人 123 例を retrospectiveに検討した.【結果】男性 92 人, 女性 21 人で, 平均年齢 $61.9 \pm 13.3$ 歳, 片側 103 人, 両側 10 人で, 初発 102 例, 再発 21 例であった。平均手術時間は $100.1 \pm 34.6$ 分（45〜 308 分), 術後の鎮痛剤使用は 46 例 $(40.7 \%)$, 術後入院期間は $5.2 \pm 2.8$ 日（2２8 日）で，合併症は 13 例 [水腫 5 例，血腫 5 例，皮下気腫 2 例, 創感染 1 例] $(10.6 \%)$ でヘルニアの再発は 3 例 $(2.4 \%)$ に認めた. 術者別の手術時間は, 初回は平均 110 分前後であったが $3 \sim 5$ 回目には 平均 80 分程度に短縮し, 熟練すれば 60 分程度で可能であった. 腹腔内 から観察するためへルニア門の見落としはなく, 再発症例でもへルニア 門の同定は容易であった，手技的には両側例でも同一創で手術が可能 で, 同じ術式で全ての単径ヘルニア（大腿ヘルニアも含む）の補強が可 能である. また, 細径器具の使用により更に手術の低侵襲化が得られ, 美容的に創曒痕は小さく術後疼痛も軽隇する（術後鎮痛剂使用は 55 例 中 7 例 $(12.7 \%))$ ため術後入院期間も短縮され $(4.0 \pm 1.1$ 日 (2〜7日)) 患 者の満足度は良好であった.【まとめ】 LH は経済的には cost が高くなる が多くの利点があり, 医療サイドからも患者の立場からも単径ヘルニア 手術においてコンセンサスの得られる手技であると考えられた.

PS16-06 となりうるか一

PS16-04 成人鼠径ヘルニアの再発・嵌頓例に対する手術の工夫 宋 圭男, 佐藤博信, 村山 公, 山形基夫, 岩井重富

(日本大学第三外科)

【対象と方法】当教室では1998 年 11 月より PHS (PROLENE*Hernia System)を用いた Anterior approach 手術を導入し，2001 年 2 月までに 鼠径ヘルニア 115 例を修復した. 同時期に行われた Bassini 法, McVay 法, iliopubic tract repair 法 (従来法) は妊娠希望の女性 3 例, 肝硬変症 などの血液凝固異常を有する 7 例の 10 例であり, mesh plug 法（MP 法)は 16 例に施行した. 115 例のうち再発例が 11 例, 嵌頓例が 3 例あり, 個々の症例に術式を工夫し良好な成績を得たので報告する. PHS 法の適 応は 1 . 成人男性 2 . 妊娠の可能性の無い成人女性 3 . 血液凝固系の異常を 除く 4. 嵌頓などの緊急手術例を除く,である. 手術の実際は 1 . 外鼠径輪 より皮膚割線に沿う約 $6 \mathrm{~cm}$ の切開 2. ヘルニア亯の高位・二重貫通結禁 3. 腹膜前筋膜浅葉の切開と preperitoneal space の剥離 4. PHS の挿入と under lay mesh の展開（最近では『精巣動静脈・精索の腹壁化 palietalization』による mesh の完全な展開) 5. on lay mesh の縫着である.【成績】 再発 11 例は全て男性で, 前回手術は従来法 9 例, MP 法 2 例であった. 再発形式は内鼠径 8 例, 外鼠径 3 例であり全例 PHS を用いて修復した. MP 法施行後の再発 2 例はいずれも術後数力月で再発していた. 局所所 見は恥骨上部に Sac が認められ, メッシュの恥骨部への縫着が破綻した のが原因と思われた。 パラソル型メッシュは内鼠径輪近くで拇指頭大に 硬化・萎縮しており, 前回使用したメッシュの摘出は困難であった. 修 復術は後壁のメッシュを切開し腹膜前腔に達し PHS の under lay mesh を展開, 後壁メッシュの前方で on lay mesh を縫着した. 嵌頓 3 例は全て 外鼠径ヘルニアの男性で, 小腸切除した 1 例は iliopubic tract repair で 修復した. 腸切除せず還納した 1 例は 25 歳であったが後壁が脆弱であ り MP 法で修復した. その他の 1 例は 52 歳で大網が嵌頓しており, 瘾着 剥離・整復後にPHS で修復した. 術後観察期間は短いが全例再発なく 経過観察中である.【結語】成人鼠径ヘルニアの再発は恥骨上部の再発が 多く, PHS を用いて充分な強度の修復ができた. 嵌頓へルニアでは腸切 除が必要な症例には未だメッシュ修復の適応はない, 腸切除しない症例 ではPHSによる修復も可能と考えられた。
荻野信夫, 道清 勉, 長谷川順一, 山邊和生, 奈良啓悟

(大阪府済生会富田林病院外科)

【目的】近年 tension free の概念の拡がりとともに腹腔鏡下鼠径へルニア 修復術や mesh plug 法が成人単径ヘルニアの治療法として広く導入さ れているがそれらの優劣については未だ決着を見ていない，当院では 1994 年より tension free repair である腹腔鏡下ヘルニア修復術 (TAPP, TEP) および mesh plug 法 (MP) を導入した. 今回これら 3 術式に Bassini 法に代表される従来法を加えた 4 術式の手術時間, 入院日数, 術 後合併症などを比較検討し, さらにQOLのアンケート調查を施行し各 術式を評価した.【対象】1993 年から 2000 年まで当科で施行した成人奧 径ヘルニア 365 例のうち従来法 49 例, MP 115 例, TAPP89 例, TEP65 例の計 318 例である.【方法】従来法, MP は腰麻下に施行され, TAPP, TEP は全麻下に施行された. アンケートは術後創痛の程度, 人工補強剤 の異物感の有無, 職場への復㷌時期, 再発の有無について質問した.【成 績]従来法, MP, TAPP, TEP の手術時間はそれぞれ平均 49 分, 48 分, 95 分, 57 分であり TAPP 群が長かった. 入院期間はそれぞれ 9.7 日, 7.3 日，7.9 日，6.6 日と差はなかった. 術後合併症は血腫, seroma が従来法 $12 \% \mathrm{MP} 8 \%$, TAPP $19 \%, \mathrm{TEP} 7 \%$ にみられ, 皮下気腫は TAPP2 例, TEP 2 例に認めた。腸管癒着，イレウスは認めなかった。再発は従来法 4.8 $\%, \mathrm{MP} 5.8 \%$, TAPP $6.2 \%, \mathrm{TEP} 6.8 \%$ に認めた. TEP の再発は術式の確 立した 96 年以後は 1 例 $(2 \%)$ のみであった. 創の大きさは TEP, TAPP がMP, 従来法に比較して小さく術後の疼痛も軽微であった.また術後の 異物感の有無については MP, TAPP, TEP の間に差はなかった。職場復 媲までは従来法 29 日, MP21 日, TAPP20 日, TEP15 日でTEPが短期 間であった.【まとめ】TEPは全身麻酔を要するが，手技に習熟するこ とにより手術時間も短縮可能であり, 低侵襲で社会復帰が早いことから 有用であると考えられた. 
PS17-01腪移植の現況と問題点：脳死㬸腎同時移植 2 例の経験か ら

打越史洋"，伊藤壽記"，弓場健義"，田中知德"，清本徹馬"，赤丸祐

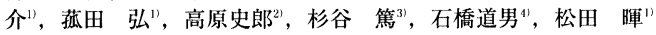
(大阪大学大学院医学系研究科機能制御外科学"), 大阪大学大学院医学 系研究科器官制御外科学 ${ }^{21}$, 九州大学臨床腫瘍外科 ${ }^{3}$, 奈良県立医科大 学泌尿器科 ${ }^{4}$ )

臓器移植法実施後, 当施設にて 2 例の潇腎同時移植術を施行した. 今回 この経験をふまえて腪移植の問題点を検討する.【ドナー,グラフト側の 問題点】2 例とも脳死ドナーの原因疾患は動脈硬化性脳血管障害であり, かつ 2 例目は高アミラーゼ血症を認めた marginal donor であった. ド ナーとレシピエントの体格のマッチングは重要で, 1 例目においては, レ シピエントに対してドナーの体格が小さかったため, 術後長期インスリ ン投与が必要であった．また逆にレシピエントの骨盤腔が小さい場合は 大きなグラフトは還納しにくいと考えられる，術式は 2 例とも膵グラフ 卜は胃十二指腸動脈 (GDA) の再建を伴う動脈 Y グラフトを用いて右腸 骨窩に，腎は左腸骨窩に移植し，外分泌は膀胱ドレナージを行った，腆 グラフトは複雑な血管再建を要し, 長時間のベンチサージャリー (197,259 分)が必要であった. しかし，GDA の再建により茀頭部の血流 は良好に保たれたと考えられ，また蓃・腎の TCIT も現在考えられる葴 器保存の許容範囲であった.【レシピエント側の問題点】 2 例とも免疫抑 制は 4 剂併用療法 (ALG or ATG, FK, PRED, MMF) を行った. 1 例目は 移植後 11 日目に, 2 例目は 29 日目に腎生検にて軽度の拒絶反応を認め たためDSGの投与を行った。このため 1 例目では骨髄抑制による白血 球滅少をきたし，G-CFS の長期頻回投与が必要であった．また 2 例目で は術後 7 日目に血栓症にて腪グラフトの摘出を行った。術後 5 日目にグ ラフト血流ドップラーの異常, 尿中アミラーゼの低下を認めており，グ ラフト血流ドップラーの重要性, 頻回の尿中アミラーゼ測定の必要性を 痛感させられた。さらに 2 例目においては術前からの循環器系合併症に FK の心毒性が重なり, 術後に難治性の心室頻拍をきたした. 腪移植にお ける FK の有用性は明らかであるが, 糖尿病患者の場合はさらに慎重な 術前合併症評価・術後モニタリングが必要であると考えられた。

\section{PS17-02 臨床䐙臟移植における2 層法の有用性と問題点} 平岡邦彦"，酒井哲也", 黑田嘉和"，鈴木康之", 藤野泰宏 ${ }^{11}$, 谷阅康 喜")，松本慎一", 具 英成", Kandaswamy $\mathrm{R}^{21}$, Sutherland DER ${ }^{21}$ (神戸大学第 1 外科", ミネンタ大学外科 ${ }^{21}$ )

【目的】酸素運搬体である perfluorochemical をUW 液と共に用いた 2 層法 (TL) はこれまで犬膵保存モデルにおいては UW 液単純保存 (UW) に比べて有効であることが証明されてきた. 今回，ミネソタ大学外科で の臨床膵臟移植において TL を応用した 15 例について UW と比較検討 し，考察を加えた.【方法】方法：1997 年 10 月から 1999 年 4 月までにミ ネソタ大学外科で施行された 79 例（TL 群 15 例, UW 群 64 例）の膵臓 移植を対象にした．朠移植術中再還流時の莿グラフトの状態，術後の腪 グラフト機能, 急性拒絶, 合併症, 遠隔成績 (最短観察期間 20 ケ月, 平 均 28 ヶ月) などについて検討した。【成績】結果：両群間でドナー及びレ シピエントの条件に明らかな違いはみられなかった，総冷阻血時間は TL 群で $16.08 \pm 4.82 \mathrm{hr}$. UW 群で $16.88 \pm 4.53 \mathrm{hr}$ であった. TL 群におけ る TL 施行時間は $9.50 \pm 4.68 \mathrm{hr}$ で, 総冷阻血時間に占める割合は 55.8 $\pm 16.2 \%$ であった。再還流時, 膵グラフトの浮腫は TL 群で $1 / 14(7.1$ \%)とUW 群 17/61 (27.9\%) よりも少ない傾向であった．入院期間中の インスリン離脱例は TL 群で $12 / 15(80 \%$, UW 群で $37 / 64(57.8 \%)$ と TL 群の方が速やかな内分泌機能を得られる傾向であった，術後滕合併 症は TL 群で $5 / 15(33.3 \%)$, UW 群で 19/64 (29.7\%) と同様であった。 急性拒絶例は TL 群で $2 / 15$ (13.3\%) とUW 群 19/64（29.7\%）よりも少 ない傾向であった。一年グラフト生存は TL 群で $12 / 15(80.0 \%), \mathrm{UW}$ 群で 46/64 (71.9\%) であった.【結論】考察：TLは臨床櫒移植において 安全に施行できるとともに移植後長期成績も良好であることが UW と の比較により確認できた. TLの問題点として総冷阻血時間に対する TL 施行時間が制限されること, 臨床移植の場では保存方法がやや煩雑であ ることがあげられる. 今後 TL 装置の工夫とともに臨床応用の拡大が期 待される.
PS17-03 腪島移植の現況と問題点一心停止ドナー提供膵の可能 性一

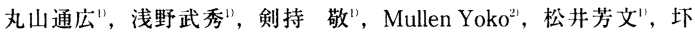
尚武", 斎藤 剛"

(千葉大学第二外科", UCLA 外科")

【目的】䐙島移植は 1 型糖尿病の根本的な治療法として, 欧米では近年盛 んに行われるようになってきた。膵葴移植と比べ，手技が簡便で低侵襲 性であること, 免疫学的に優位であること, 拒絶されてもグラフトを摘 出する必要がないこと等の理由で優れた治療法といえる. 今までの移植 データから，一度に大量（6,000 IEq $/ \mathrm{kg}$ 以上）の萭島を移植することが 必要と言われており, one donor から大量の純度の高い苏島を採取する 必要がある.このため, 脳死 donorの新鮮な䐙からの分離が望まれるが, 現在の我が国の法律では脳死 donor からの腪島分離は不可能であり，心 停止 donor からの滕を利用する方法しか選択できない.心停止 donor からのグラフトには心停止:までの死線期やその後の温疎血などの問題 があり, 腪島への影響が懸念される. 今回, 死線期やその後の温䠅血が 膵島収量に与える影響を検討した. 【方法】 UCLA Islet Transplant Programにおける腆島分離 310 例の経験において, donor の死因, 在院期 間，心肺停止の有無，カテコラミン投与量などの donor 因子が苏島収量 に影響を与えるかどうかを統計学的に検討した．さらに温柾血実験で は，30 分間の温疎血を加えたイ又を用い， $\mathrm{CMH}$ 液による死体内潅流後 腪摘出, 千葉大式分離法にて膵島分離し, 非心停止群と比較検討を加え た.【結果】莿島収量は donor の死因, 在院時間, 心肺停止の有無, カテ コラミン投与量などの donor 因子には統計学的に影響されなかった. 温 疎血群 $(\mathrm{n}=7)$ の茲島収量は $5.196+2.528 \mathrm{IEQ} / \mathrm{g}$, 純度 $74.2+9.8 \%$ で, 非心停止（n=14）の9,463+3.775, 89.3+6.5に比し低下がみられたもの の, 形態, perifusion assay に扔ける機能も良好に保たれていた.【結論]脑 死 donor からのグラフトが䐙島分離に使用できない現状において, 心停 止 donor から提供される莿臓も十分滕島移植に適すると考えられ，多く の移植待機患者に福音がもたらされるものと考える.

PS17-04 鞉島分離前の滕保存における二層法の必要性

谷岡康喜"，高橋 毅"，鈴木一永 ${ }^{22}$, 辻村敏明", 平岡邦彦", 藤野泰宏", 鈴 木康之", 具 英成", 黑田嘉和"

(神戸大学第一外科", 神戸大学老年科"

【目的】蓃島移植は, 手技の簡便性, 安全性の点で, 愺臟移植に勝り, 免疫抑 制剤の進歩等で成績も向上し, 治療法の一つとしての確立が望まれる.一方, 現状では one donor one recipient が困難で，一捇からの脾島收量を如何に高 めるかが最大の課である。更には脳死ドナーの極端に少ない我が国の場合， 心停止下摘出䐙からも十分量の捇島が得られることが必須といえる。

我々は膵瀻移植における臓器保存法として, 二層法を開発し, その有用性を 報告してきた，今回，䐙島分離前の䐙保存法として二層法が有効かどうかを 䐙島収量の観点から検討した。

【方法 1】イヌ茦を摘出後二層法あるいは UW 液にて保存し, 满島収量を比較 検討した.

【方法 2】手術時に摘出されたヒト腪を一層法にて 24 時間保存後に膡島分離 を行い，その収量を検討した。いずれも捇の分離は Ricordiらの automated collagenase digestion method によって行ったままた，2において，苹島の純 化は Euro-Ficoll の不連続密度勾配法にて行った。

【成績 1】摘出後直ちに䐙島分離した場合（コントロール）の愺島収量は 7900 IEQ/g pancreas であった. 摘出茦を二層法にて 24,48 時間保存した後に䐙島 分離した際の櫒島収量はそれぞれ 7800,7300 であり，コントロールと同等の 収量が得られた.一方, UW 単純浸漬にて 24.48 時間保存した後の腪島収量は それぞれ 6600,3000 であり，䏬島収量は有意に隇少した。

【成績 2】ヒト滕を摘出後, 24 時間二層法保存した場合の滕島収量は $2800 \mathrm{IEQ}$ /g pancreas $(\mathrm{n}=7)$ であった，そのうち温阻血 30 分以内に摘出し，二層法保 存を行った症例 $(\mathrm{n}=4)$ の茦島収量は $3800 \mathrm{IEQ} / \mathrm{g}$ pancreas であった. 一方, 摘出時の温阻血が 30 分以上の場合 $(n=3)$ はその収量は 1500 であった。

【まとめ】二層法においては 48 時間保存後まで膵島収量はよく保たれ, 現状 のUW 単純浸漬保存より極めて有効な保存法といえる. 更にヒト豚において は限られた時間ではあるが, 二層法により温阻血䐙からも従来に匹敵する䐙 島収量が得られた。

【結論】膵島分離前の满保存には UW 単純浸漬保存にかえて二層法の使用が 望ましい。 
PS17-05多臟器合併移植の免疫学的有利性 : Green Florescent Protein (GFP) Transgenic ( Tg) ラットを用いた解析 佐久間康成 ${ }^{1}$, 久米晃啓 ${ }^{2}$, 永井秀雄 ${ }^{11}$, 内田広夫 ${ }^{21}$, 田原和典 ${ }^{21}$, 袴田陽 二"2，上田正次 ${ }^{33}$ ，高橋将文 ${ }^{21}$ ，小林英司 ${ }^{21}$

(自治医科大学", 分子病態治療研究センター", YSニューテクノロ ジー3)

㬸・腎同時移植のような多臓器合併移植の免疫学的有利性は, 移植時に 多くの donor passenger leukocyte（DPL）が移入されることに基ずくと 考えられている.しかし，DPLの移植後の運命については不明である. 先に我々は, 白血球系に強い蛍光輝度をもつ GFP T g ラットの作成に成 功しており, 今回本ラットをドナーとしたラット菜/脾合併移植 (PST) を行い多脸器合併移植の免疫学的有利性を検討する目的でレシピエン ト体内におけるDPLの解析をおこなった. (方法) タクロリムス使用下 $(0.64 \mathrm{mg} / \mathrm{kg}$ 筋注 $/ 2$ 週) で GFP Tg Wistar をドナー, ストレプトゾトシ ン誘導糖尿病 LEW をレシピエントとしPST または䏺単独移植 (PT) を 行った. GFP 陽性細胞の動態をフローサイトメトリーを用いて解析し た. (結果) PT 群における腨グラフトの生着期間は最長で 21 日で, 末梢 血中の GFP 陽性細胞は $1 \%$ 以下であった, 一方, PST 群では移植後早期 でレシピエント死亡が見られたが苏グラフトは, 30〜40 日と長期生着を 認めるものもあった，满グラフトの長期生着レシピエントは, 移植後 GFP 陽性細胞数を増やし顆粒球は最高で $48 \%$ に及んだ. (結語) 脾の合 併移植によりキメラリズムが強まりこれが腪グラフトの長期生着に寄 与したものと考えられた。
PS17-07 Tissue engineering of a chondrocyte immunoisolation barrier for encapsulation of islets of Langerhans.

Pollok JM, Torok E, Lorenzen M, Kolln PA, Kaufmann PM, Kluth D, Bohuslavizki KH, Gundlach M, Rogiers X

(University of Hamburg)

Purpose : We wanted to demonstrate the long-term function of glucoseinsulin feedback of islets of Langerhans within a capsule of chondrocytes, which may serve as an immunoisolation barrier utilizing the immuno-privileged properties of the chondrocyte matrix. Methods : Islets of Langerhans were isolated from Lewis rats and seeded on a biodegradable polyglycolic acid (PGA) polymer and encapsulated with a monolayer of chondrocytes. The encapsulated constructs were kept in culture medium with a glucose content of $100 \mathrm{mg} / \mathrm{dl}$ for five weeks with a glucose challenge of $400 \mathrm{mg} / \mathrm{dl}$ every fifth day. The secretion of insulin was measured using a radioimmunoassay. Results : H\&E histology demonstrated viable islets of Langerhans after 36 days in culture. Toluidine-Blue stains showed a complete capsule of chondrocytes around the islets. Immunohistochemistry displayed positive staining for insulin within the beta cells of the islets. Both encapsulated constructs as well as non-encapsulated controls showed an increase in insulin secretion into the culture medium after the glucose challenge. Conclusions : Islets of Langerhans survive within the chondrocyte capsule up to five weeks in culture. The glucose/insulin feedback mechanism of the encapsulated islets remains intact for up to three weeks in culture. The chondrocyte capsule permits free diffusion of glucose and insulin.
PS17-06 NOD マウスを用いたアガロースマイクロカプセル化膵 島同系移植

小林経宏, 青松幸雄, 金廣裕道, 久永倫聖, 高 済峯, 長尾美津男, 池 田值也, 鹿子木英毅, 金村哲宏, 葛本幸康, 福本晃久, 岡山順司, 小川 護仁, 中島祥介

(奈良県立医科大学第 1 外科)

【背景】1 型糖尿病に対する膵島移植の成績は不良であるが,これは拒絶 反応もさることながら, 移植片が自己免疫反応による破壊を受けること がその原因であると考えられる.垭島移植の適応疾患の大半は 1 型糖尿 病であり, 自己免疫による $\beta$ 細胞の破壊を防御することが重要な課題で ある.【目的】アガロースマイクロカプセル (MC) にて免疫隔離を行い, islet graft と免疫担当細胞との cell-cell contact を阻害することにより, 自己免疫による $\beta$ 細胞の傷害を制御し得るかを検討した.【方法】糖尿病 発症前の雄性 NOD マウス $(6 \sim 8$ 週齢) より粗島を単離. 糖尿病雌性 NOD マウスの腹腔内および omental pouch 内に, 裸の腪島, MC 化膆島 を移植, 随時血糖値・graft 生着日数を比較した。随時血糖值 $200 \mathrm{mg} / \mathrm{dl}$ 以下を正常血糖とした. Omental pouch 移植例については graft を摘出 し組織学的に検討, graft 摘出前後の血糖推移を観察した.【結果】A 群 (裸の腪島群, $\mathrm{n}=3$ ) では, 移植後一旦血糖值が低下し, それぞれ 8.8 , 13 日間（平均 9.7 日）正常血糖を持続したが, その後血糖値が再上昇し それぞれ 25,50,35 日目 (平均 26.4 日目) に死亡した. B 群 (MC 化苏島 群, n=6) では, 移植後速やかに血糖値が低下し, それぞれ現在移植後 $100,41,36,22,20,13$ 日目 (平均 38.7 日) の時点で正常血糖を持続し生存 中である.两群間の生着日数に有意差を認めた $(\mathrm{p}<0.01)$. Omental pouch 移植例では, 移植後血糖值は速やかに低下し 100 日以上の長期生 着を認めた. 150 日目に graft を摘出したところ血糖値は 400 以上に上 䄯した. graft の組織像では MC の中に viable 膵島を認め, 免疫染色に てインスリンの産生が確認できた，MC周囲には新生した毛細血管を認 めた. 自己の滕組織にはインスリン産生は認められなかった.【結論】 NOD マウスを用いた腪島同系移植モデルにおいて, アガロースマイク ロカプセル化により自己免疫による graft 破壊を防御し得た.
PS18-01多能性肝幹細胞の制御による再生治療への展望 谷口英樹, 高田泰次, 清野研一郎, 小池直人, 川本 徹, 湯沢賢治, 足 立信也, 野末 睦, 大塚雅昭, 继 健, 深尾 立

(筑波大学臨床医学系外科 (消化器))

【目的】幹細胞を人為的に制御し，いわば種子から再び器官形成を誘導 するのが「臟器再生」という新しい治療概念である. 我々は, 単離した 肝細胞集団の中から極少数しか存在しない肝幹細胞を FACS (fluorescence activated cell sorting）を用いた精度の高い細胞分離法により純化 回収し, 肝幹細胞をもちいた治療体系の構築を試みた.【方法】胎生 13.5 日マウスの肝臟から細胞を単離し, FACS で回収した各細胞画分の 機能解析を行った．画分化の指標として，血球特異的抗原である CD45 ・TER119, 肝細胞增殖因子レセプターである c-Met, 幹細胞增殖因子レ セプターである c-Kit, 各インテグリン発現量をもちいた. 単細胞培養を 行い，形成されたクローン性コロニー数を計測した．各コロニーにおい てRT-PCR 法と免疫染色法をもちいて肝細胞および胆管細胞マーカー の発現を解析した. 明らかとなった幹細胞の自己複製を培養系において 誘導し，レトロウイルスベクターを用いて GFP 遺伝子を導入した後細 胞移植を行い肝組織再構築能を検討した.【結果】各画分におけるコ口 ニー数を解析したところ, 全肝臟中の僅かに $0.3 \%$ を占めるにすきない c-Met + c-Kit-CD49f + /lowCD29 + CD45-TER119 - 細胞中にのみ, 增殖 能の高い幹細胞が存在することが判明した．各々のコロニーでは, アル ブミンなどの肝細胞マーカーと, サイトケラチン 19 などの胆管細胞 マーカー陽性細胞が共に認められ, これらの幹細胞は多分化能を持って いることが明らかとなった。この細胞は著明に増殖し, 効率の良い遺伝 子導入が可能であった (導入効率 $>95 \%$ ). さららに, 移植後 GFP 陽性細 胞による肝組織が維持された.【結論】增殖能・多分化能・自己複製能 ・組織再構築能を兼ね備えた多能性肝幹細胞の純化回収法, 培盖系にお ける自己複製を伴う増殖法, 遺伝子導入法, 細胞移植法などの「幹細胞 をもちいた㖑器再生」という革新的な治療体系に関する基盤技術を確立 した. 
PS18-02 内胚葉レポーティングマウス ES 細胞を用いた高効率内 胚葉分化誘導法の検討

廣瀬哲朗", 安近健太郎 ${ }^{2}$, 山岡義生 ${ }^{21}$, 中过憲夫 ${ }^{3}$

(京都大学再生医科学研究所再生医学応用部門", 京都大学医学研究科 消化器外科 ${ }^{21}$, 京都大学再生医科学研究所発生分化研究分野 ${ }^{32}$ )

【目的】移植医療におけるドナー不足を細胞治療などの治療戦略でブ レークスルーするにはドナー肝以外からのヒト細胞入手が必要となる. 我々は近い将来本邦でも樹立されるであろうヒト ES 細胞株から分化誘 導される内胚葉系細胞の利用を想定している. そこで今回はマウス ES 細胞で内胚葉への分化をレポートするシステムを作製し, 高効率内胚葉 分化誘導法を検討したので報告する.【方法】内胚葉マーカーであるアル ブミン遺伝子の組織特異的発現を規定する enhancer, promoter 配列下 に green fluorescent protein (GFP) 遺伝子を ligation L, 内胚葉 reporter gene を作製した．それを高分化傾向の C57BL/6 系マウス ES 細胞に遺 伝子導入したうえ薬片選別し, その後強力な promoter 活性を有しアル ブミン enhancer 活性を干涉する薬剤耐性遺伝子を Cre/loxP 系にて切 り出すことで, 内胚葉分化をレポートする $\mathrm{ES}$ 細胞株（ECRES）を樹立 した. ECRESにて作製された肧葉体に ES 培地, ActivinA $(100 \mathrm{ng} / \mathrm{ml})$, FGF $(100 \mathrm{ng} / \mathrm{ml}), H G F(1 \mathrm{mg} / \mathrm{ml})$, 全胚培盖系を用い内胚葉分化効率 を比較検討した. [結果】 ECRES 胚葉体では形成後約 8 から 9 日目に GFP 強発現をその内部構造に認めた. これは RT-PCR でのアルブミン 強発現時期と一致し, 他の内胚葉マーカーとの共発現も認められる一 方, CD31 など他胚葉マーカーとの共発現は認められなかったことから, ECRES による内胚葉分化レポートの適正さが示唆された. ES 培地, ActivinA, FGF, HGF, 全胚培盖系の比較では GFP 発現は全肧培養系で最も 高く, 内胚葉分化誘導における全胚培盖系の有効性が示された.【総括】 内胚葉分化をレポートする ES 細胞株 (ECRES) を樹立した. マウス ES 細胞内胚葉分化誘導には全胚培養系が有用であると考えられた。 ヒト ES 細胞株が樹立された際の内胚葉系細胞分化誘導法の参考になると考 えられた。

PS18-03 マウス胚性幹細胞 (ES cell) より分化した embryoid body における肝細胞に特異的な albumin promoterの発現

飯干泰彦, 北山保博, 井原欣幸

(国立呉病院小児外科)

目的：遺伝病および難病の治療として再生医療の臨床応用が期待され る. 我々は, マウス肧性幹細胞（ES cell）を肝細胞に分化させ, 肝細胞 のみを選択し, 疾患モデルマウスに肝細胞移植を行い, 治瘾せしめると いう再生医療の臨床応用を目的とした技術開発を目指している。 今回, マウス ES cell に肝細胞に特異的なマウス albumin promoter 領域を含 んだ vectorを transfection し, ES cell を培養し, embryoid body を形成 していく中で, この albumin promoterの発現を検討したので報告する. 方法 : マウス albumin promoter 領域の下流に, 細胞培養中に蛍光顕微 鏡で発現を確認する目的で green fluorescent protein (GFP) を, また, 将来肝細胞のみ選択する目的で hygromycin resistance gene を含んだ vector を作成し, ES cell に transfection した.この ES cell 培養液中から leukemia inhibitory factor を抜き, ES cell を分化させて embryoid body を形成させ, albumin promoter の発現を検討した. 結果：ES cell の分化 を開始後, 12 日目に albumin mRNA の発現を northern blottingにて embryoid body 内に確認できた. 蛍光影微鏡による観察では, 培美液内 で拍動する心筋に接して GFPにて光る細胞群が認められた. 考案：、 ウス胎児においては, 胎生 8 日前後より albumin の発現がみられるが, マウス embryoid body においては, 分化開始後 12 日目に albumin の発 現が認められた. 肝細胞特異的に発現するとされる albumin promoter の embryoid body 内に㧍ける発現細胞群は, 心筋に接する内胚葉領域に 存在し, マウス胎児と同様に embryoid body 内でも, 肝細胞の発生が心 筋組織によって誘導される可能性が示唆された。
PS18-04 マウス ES 細胞を用いた in vitro 及び in vivo での肝実質 細胞への分化誘導の検討

原譲"，鎮西亮子"，寺本研一"，川村 徹"，岡本浩之"，工藤

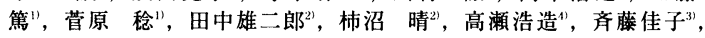
寺岡弘文 ${ }^{3)}$, 寺田直弘 5 , , 有井滋樹"

(東京医科菌科大学第 1 外科", 東京医科歯科大学消化器内科 ${ }^{2}$, 東京医 科菌科大学難治疾患研究所 ${ }^{31}$, 東京医科歯科大学医療情報 ${ }^{11}$, フロリタ 大病理 $\left.{ }^{\prime \prime}\right)$

【はじめに】肝移植医療は現状では生体肝移植に頼らざるを得ない。一 方, 幹細胞よりの臨床的アプローチが可能となりつつある.【目的】肧性 幹細胞 (embryonic stem cells, ES 細胞) より分化させた肝細胞移植治療 を目標に, マウス ES 細胞を使用し肝実質細胞への分化誘導に関する基 礎的研究を行った.【方法】マウス ES 細胞を leukemia inhibitory factor (LIF) を除いた培地でハンギングドロップ法にて肧様体 (embryoid body, EB) に誘導後, ゼラチンデイッシュ上で LIF 非存在下にて生育し たEBのアルブミン (ALB) と $\alpha$-フェトプロテイン (AFP) の遺伝子 発現を RT-PCR により検討した. 更に, マウス ES 細胞および単離した $\mathrm{EB}$ 由来細胞を $5 \times 10^{5}$ 個ずつ, 肝部分切除加の $\mathrm{ES}$ 細胞と同系の 6-7 週齢マウスに筋注, 脾注, 門注を行い, $\mathrm{ES}$ 細胞および $\mathrm{EB}$ 由来細胞の生 体内における分化傾向を組織学的に検討した.【結果】EBにおける ALB の発現は Day 9 から認められ, その後, 発現は経時的に增加した. AFP はDay3 以降で発現が見られた. 肝実質細胞成熟因子であるオンコスタ チン M の添加による ALB の発現状況や組織化学的方法などによって 肝実質細胞への分化を現在検討中である. 細胞移植実験では, ES 細胞移 植では, 筋肉内, 脾蔵や肝蔵に奇形腫が高頻度に認められたが, $\mathrm{EB}$ 由来 単離細胞の移植では稀であった．また播種によると考えられる局所的な $\mathrm{ES}$ 細胞增殖塊が筋肉内に認められたが, この練胞塊は, ES 細胞が未分 化のまま筋肉内にて増殖しており, 奇形腫への分化は認められなかっ た.【結語】臨床応用を目標に ES 細胞の in vitro と in vivoにおける肝実 質細胞分化を総合的に解析し, in vitroにおいてはすでに ALB・AFP の発現には成功した.

PS18-05 ラット門脈結禁モデルにおける AFP 陽性細胞の増生に つい

伊勢憲人, 安井應紀, 佐藤 勤, 黒川敏昭, 渡邊 剛, 安藤秀明, 小山 研二

(秋田大学第一外科)

【目的】ラット化学発癌モデルでは門脈周囲に肝上皮細胞が出現する.こ の細胞は肝細胞または胆管細胞への分化可能な肝幹細胞と想定されて いるが, 肝血流障害時でのこのような細胞の增加の有無についてはまだ 報告されていない。一方臨床において, 広範肝切除が必要な症例では, 事前に担癌葉の門脈塞栓を行い肝切除を施行している. 門脈血流障害時 に肝幹細胞の增殖が確認できればヒト肝㖑からこの細胞の効率のいい 採取が可能となる. 今回我々はラット門脈結紫モデルを用いて門脈結禁 葉で AFP 陽性細胞が增生することを確認し, この細胞を分離したので 報告する.【方法】1. 実験動物：6〜8 週の雌 SD ラット(体重 160〜200g) を用いて， $2 / 3$ 領域の門脈を結禁した後，1,3,5,7,9,11, 14, 16, 18,21, 23, 25,28 日後に鉌牲死させ肝荿を摘出した. 2. AFP 陽性細胞の出現頻度： 結紮葉と非結紮葉それぞれで免疫組織染色を行い, AFP 陽性細胞の出現 頻度を肝細胞 1000 個あたりで比較した. 3. AFP 陽性細胞の分離：門脈 結紮後 $3,7,14$ 日後に肝上部下大静脈からの灌流法にて細胞分離し, それ ぞれにおいて形成されるコロニ一数を数え, 正常ラットにおけるコロ ニー数と比較した. 4. 分離細胞を免疫組織染色で characterization した. 【結果】1.門脈結禁葉において結禁 3 日後から AFP 陽性細胞の増生がみ られ7日後にピークに達しその後徐々に隇少した. 非結禁葉では AFP 陽性細胞の增生はみられなかった. 2 . 分離細胞によって形成されたコロ 二ー数は結禁 7 日目で最も多く, 14 日目でも正常ラットより多くのコロ 二ー形成を認めた. また, 分離細胞は継代培養可能であった. 3. 分離細 胞は AFP 陽性, Albumin 陰性であった.【結論】門脈結禁葉において AFP 陽性細胞の增加を確認したここの細胞は門脈血流障害によって惹起 された継代培養可能な細胞でり, 正常ラットよりも効率よく採取するこ とができた. 